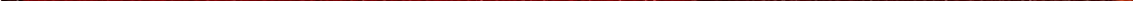




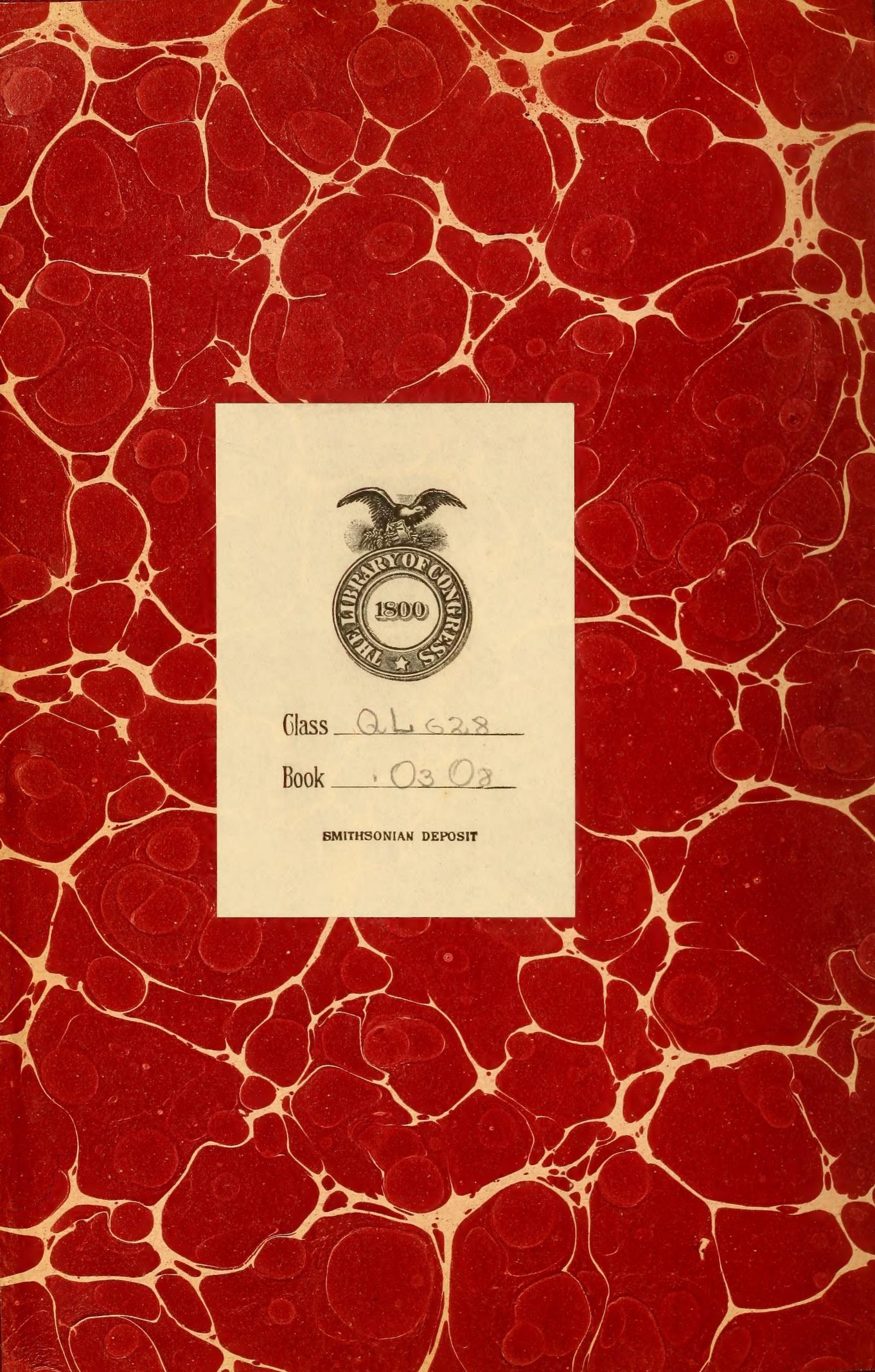




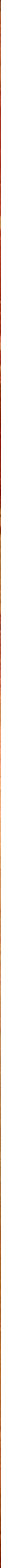





$$
\text { . }
$$

- 

Ohio State Academy of Science * * Special Papers No. 4. * *

\section{The Fishes \\ of \\ Ohio \\ 努}

$\boldsymbol{B} \boldsymbol{Y}$

RAYMOND C. OSBURN, M. SC.

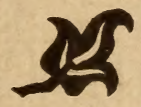

451109

Published by the Academy of Science with the Emerson McMillin

Research Fund.

« May, 1901 « 



\section{Ohio State Academy of Science.} SPECIAL PAPERS, No, 4.

\section{The Fishes of Ohio.}

BY

RAYMOND C. OSBURN, M. SC.

PUBLISHED BY THE ACADEMY OF SCIENCE

WITH THE EMERSON MCMILLIN RESEARCH FUND.

$$
\text { MAY, } 1901 .
$$


NOTE.

The investigations upon which this paper is based were made under two grants of fifty dollars each from the Emerson McMillin Research Fund, and the results are now published by the further aid of the same fund.

F. M. WEBSTER,

H. C. BEARDSLEE, WILLIAM R. LAZENBY,

Trustees. 
DEDICATION.

To the memory of my dear friend and teacher, the late Professor David Simons Kellicott. 



\section{THE FISHES OF OHIO.}

An Authenticated List, with Especial Reference to Occurrence and Distribution.

\section{INTRODUCTION.}

THE purpose of this work is to bring together the results of the investigations on the fishes of Ohio, which have from time to time been made in various localities within the state, and to compile an authenticated list of the fishes of Ohio, which shall include only such species as have been definitely reported for the state by some collector. An attempt has also been made to show the distribution in the state, of each species, by citing all the records of occurrence which could be obtained. The results show that many species are so widely distributed and so abundant that they have been taken by every collector in the state; some are widely distributed, but nowhere common; others have been taken commonly in one or two localities, but not elsewhere; and still others are so rare that only single individuals have been recorded.

Before proceeding with the list it may be of interest to glance at the work of some of the collectors of Ohio fishes, as shown by their publications.

The work in the Ohio Valley was begun by C. S. Rafinesque, in a paper dated at Louisville, Kentucky, July 20, I8I8. This paper was followed by a number of others in rapid succession, and in December, I8I9, to November, I820, Rafinesque published in a series of articles in the "Western Review and Miscellaneous Magazine," his "Ichthyologia Ohiensis," which, as Dr. Call says, "laid the literary foundation of American Ichthyological Science." As Rafinesque's paper covered the Ohio River System, it is not definitely known how many species he took within the limits of Ohio, but he mentions about twenty-five 
species as occurring in the streams of the state, Muskingum, Hocking and Miami Rivers and the Ohio River " as far as Pittsburgh." Rafinesque makes mention of one hundred and eleven species as occurring in the Ohio and its tributaries, but of this number, as Dr. Jordan says, " upwards of forty-three are either spurious or redundant." Of the one hundred and thirty-four native species now recorded for Ohio, Rafinesque described thirtyfour. Further comment on Rafinesque's work is unnecessary, as it has been reviewed by various later writers, especially by Dr. Jordan. Dr. R. E. Call has recently published an edition of the Ichthyologia Ohiensis in the original text, accompanied by a biographical sketch.

The first paper to appear, dealing entirely with the fishes of the state, was that by Dr. Jared P. Kirtland, published in the Second Annual Report of the Geological Survey of Ohio, and bearing date of November I, I838, at Cincinnati. In this paper Dr. Kirtland gave a list of serenty-two species belonging to Ohio. Of this number, at least twelve are redundant. In the "Family Visitor," of 1850, however, Kirtland gave a corrected list, in which seren doubtful species of his former list were omitted, and two other species added, thus reducing his list to sixty-seven species, of which number at least sixty-one are good. Kirtland published other papers on Ohio fishes, his most important work being "Descriptions of the Fishes of Lake Erie, the Ohio River and their Tributaries," which appeared in the "Boston Journal of Natural History," as a serial, in 1840-46. Eight species of our present list were described by Dr. Kirtland, and his careful work resulted in many valuable contributions to ichthyological knowledge.

The next work of importance on Ohio fishes was that of Mr. John H. Klippart, of the State Fish Commission, published in the first and second annual reports of the commission. The first report, for the years $1875-76$, contains descriptions of twenty-five species "copied and arranged from the manuscript of Prof. D. S. Jordan, by his assistant, Chas. H. Gilbert,"' with comments and notes by Klippart, and with plates of nineteen species drawn by Miss Josephine Klippart. The same report also contains a list of one hundred and eighty-five species of fishes "supposed to occur 
in Indiana, and therefore in Ohio." In regard to this, Klippart remarks, "Messrs. Jordan and Gilbert's Catalogue of the Fishes of Indiana is here given, under the belief that the same species of fishes found in Indiana south of the watershed may be found in the waters of Ohio." The list contains many species not recorded for Ohio after the lapse of a quarter of a century, and some that, owing to peculiarities of distribution, probably never will be taken. The second report contains descriptions of twenty-four species " arranged from manuscript of Prof. D. S. Jordan, by his assistant, Mr. Ernest Copeland," with plates of sixteen species. As a whole the reports contain much that is good.

By far the most important paper on Ohio fishes is that by Prof. David Starr Jordan, published in the fourth volume of the Report on the Geology of Ohio, entitled a "Report on the Fishes of Ohio," and bearing date of December 10, 1878. Dr. Jordan was at that time connected with Butler University, in Indiana, and his services in the preparation of the report were engaged by Prof. J. S. Newberry, the State Geologist of Ohio. This report contains, besides the synonymy and many valuable notes in regard to habits, careful descriptions of a hundred and sixty-five species of fishes supposed to occur in Ohio. Of this number, nine have since proved to be redundant, while three others have been reduced to varietal rank. Of the remaining number described, more than fifty had not at that time been taken within the limits of the state, but were included because their range was such as made their occurrence within the state probable. Many of these have since been noted, but at the time of publication of Jordan's Report only about one hundred species had been recorded for the state.

Following Jordan's Report, in more recent years have appeared a number of papers dealing with investigations more local in their nature, but all contributing materially to our knowledge of the occurrence and distribution of Ohio species. The first of these of which I have any knowledge, appeared in the Journal of the Cincinnati Society of Natural History, for JulyOctober, I 888, under the title, "Contributions to the Ichthyology of Ohio, No. I," by Dr. J. A. Henshall, and gave a list, with occurrence notes, of seventy species noted in Hamilton County. 
This was followed in January, I889, by a second paper, more general in its nature, adding forty species noted at various points in the state, and making a state list of a hundred and ten species noted by himself. Localities were given for all the species mentioned.

In 1892 appeared "A Descriptive List of the fishes of Lorain County, Ohio," as "Laboratory Bulletin No. 2," of Oberlin College, by Mr. L. M. McCormick. This list includes eightyeight species "resting upon specimens preserved in the museum," with brief descriptions, and notes on occurrence and habits, and with plates of eighteen species.

In I893, Dr. Philip H. Kirsch, at that time Fish Commissioner of Indiana, investigated the Maumee River and its tributaries, under the direction of the U.S. Commission of Fish and Fisheries. Kirsch's paper, "Report upon Investigations in the Maumee River Basin During the Summer of 1893 " (Bull. U. S. Fish Com., I 894), includes a list of eighty-seren species of fishes, with descriptions of the streams and lakes of the system, and many interesting notes. The report includes the unpublished notes of a small collection of fishes made in Defiance County by Prof. S. E. Meek, in I887. Although the investigations covered portions of the Maumee Basin in Indiana and Michigan as well as in Ohio, the occurrences for each locality are definitely noted, and eighty-two of the eighty-seven species mentioned by Kirsch are recorded for localities in Ohio.

In the summer of $1897, \mathrm{Mr}$. E. B. Williamson and the writer investigated the streams of Franklin County, and published the results in a paper entitled "A List of the Fishes of Franklin County, Ohio, with a description of a new species of Etheostoma, by R. C. Osburn and E. B. Williamson" (Sixth Annual Proceedings of the Ohio State Academy of Science, 1898). The list includes sixty-nine species, with occurrence notes, and some color notes on the rarer species, together with many breeding dates, and a table showing distribution.

A somewhat similar investigation was carried on in the summer of 1898 , by Messrs. J. B. Parker, E. B. Williamson and the writer, and the results appaared in the Seventh Annual Proceedings of the Ohio State Academy of Science, 1899, under the title, 
"A Descriptive List of the Fishes of Big Jelloway Creek, Knox County, Ohio." Many color descriptions of species in high breeding coloration are given, and some interesting breeding and occurrence notes.

Prof. E. B. Williamson has kindly furnished the author with an unpublished list of trenty-six species taken by him in the vicinity of Salem, Columbiana County.

During the summers of 1899 and I900, aided by a portion of the Emerson McMillin fund of the Ohio Academy of Science, the writer was enabled to investigate some parts of the state not before studied, and, as the general distribution of the food fishes was already quite well known, attention was turned more directly to the smaller and less conspicuous species. As a result of the investigation, several species not previously noted have been added to the list for the state, and a number of rare species recorded for new localities and their range extended, while the knowledge of the distribution of many of the more common species in the state has been considerably furthered. Ten days spent in the vicinity of Ironton, seining in the Ohio River and Ice Creek, a small tributary of the Ohio, and in Johns Creek, a tributary of Symmes Creek, gave some interesting results. The Ohio River, with its tributaries, Wheeling Creek and McMahon Creek, was also seined in the vicinity of Bellaire. The shallow waters of Sandusky Bay were hauled in many places and Notropis heterodon was added to the state list. The Huron River, with one of its small tributaries, was seined in the vicinity of Milan, and fifty species, nearly all common, were taken. Ashtabula Creek, in Ashtabula County, was seined, but yielded only a meager list, due to the fact that the stream flows for nearly its whole course over a solid shale bottom. The small streams forming the headwaters of the Wabash River, in Mercer County, yielded a good representative list, forty-nine species being taken. Stillwater and Wolf Creeks, tributaries of the Miami, near Dayton, were hauled; and Exoglossum maxillingua taken-a most unexpected find. The Cuyahoga River and its tributary, Breakneck Creek, were seined near Kent, and the Cuyahoga again at Hawkins; Grand River, with its small tributaries, was hauled for some distance above Painesville, and the Chagrin River was 
touched at Willoughby ; Chippewa Lake, near Medina ; Summit Lake, at Akron, and Pippin Lake, near Kent, were investigated, and some time was also spent at Buckeye Lake, better known as the Licking Reservoir; and the North Fork of Licking River, with some of its small tributary streams, was seined near Newark. The results of these investigations will be found embodied in the occurrence notes of the following list.

No attempt was made to collect the parasites of fishes, but iri a few cases these were common enough to attract the attention of even the casual observer. In Ashtabula Creek a species of leech was found attacking the catfish. The largest of the leeches were about one and one-half inches in length. They were found usually attached to the lower jaw among the barbels, which in color they closely resembled. Not a catfish was taken in this stream but what bore the evidence of the work of this parasite, and frequently a half dozen leeches would be found on a single small catfish. In the headwaters of the Wabash River, in Mercer County, a species of crustaceous parasite was found in great numbers attacking especially the suckers and minnows. So numerous were they that it was difficult to find individuals of Catostomus commersonii and Campostoma anomalum, the species most affected, without at least one of these parasites. The points of attack were chiefly the regions immediately behind the pectoral and ventral fins, probably because they were most protected in such position. A Myxosporid parasite attacking Notropis cornutus was noted for a number of localities in central and northern Ohio. This species has been partially described by Linton (Psorosperm of Notropis megalops [comutus], Linton, Bull. U. S. Fish Com. for I889 (I89I), IX, pp. 459-6I, pl. I20, figs. I-3), from specimens taken by Mr. L. M. McCormick, in Black River, Lorain County, September I, I890, and again on October 5, I89I; and Gurley mentions it with additional notes ("The Myxosporidia or Psorosperms of Fishes,"' by R. R. Gurley, Report of the Commissioner of Fish and Fisheries for I892 (I894), I2. Genus et sp. incert., pp. I82-3, pl. 7, figs. I-3). This Psorosperm has been noted by the writer on $N$. cornutus from Franklin County, and from Licking Reservoir in the Ohio River drainage, and from Huron River, Cuyahoga River, Grand River, and Chagrin River, 
tributary to Lake Erie. The species is evidently not, as believed by McCormick, " restricted to a very narrow geographical range." The cysts formed by this parasite reproducing in the subcutaneous tissue may reach a diameter of one-third inch, and as many as eleven cysts have been noted on a single fish. It would seem that in some cases they must inevitably cause the death of the host.

Specimens of all the species of fishes recorded by Kellicott, Williamson, Parker and the writer are deposited in the museum of the Ohio State University.

In the preparation of this paper free use has been made of the works of the various writers on Ohio fishes, of "The Fishes of North and Middle America" (Bulletin 47, U. S. National Museum), by Drs. David Starr Jordan and Barton W. Evermann; of Dr. O. P. Hay's "Lampreys and Fishes of Indiana" (Igth Annual Geol. Rept. of Ind.), and of the reports and bulletins of the U. S. Commission of Fish and Fisheries. The classification is that adopted by Jordan and Evermann in Bulletin 47, U. S. Natl. Mus. The keys for the separation of families, genera and species have, for the most part, been taken from the same work, but modified and abridged to meet the requirements of the more limited scope of this paper. The descriptions have been drawn largely from the same source, but as far as possible these have been verified for Ohio specimens, and modified as occasion demanded to make them apply more closely to the species as found in Ohio.

While it is not the purpose to discuss in this paper the general anatomy of the fish, such as may be found in any good laboratory guide on zoology, a few hints to the beginner in regard to methods of procedure and to some particular points of structure may here find a place. The teeth in some species are borne on nearly all parts of the mouth and pharynx-premaxillaries, maxillaries, mandibles, romer, palatines, tongue, hyoid -apparatus, pterygoids and pharyngeals, but may be wanting from :any or all of them. The examination of all but the last mentioned can usually be satisfactorily made through the open mouth by using a blunt dissecting needle or the head of a pin as a "ffeeler." It is the determination of the number and arrange- 
ment of the lower pharyngeal teeth that constitutes the particular "bête noire" of the uninitiated, but this must be mastered or many identifications will be impossible. The lower pharyngeal bones form the fifth pair of gill arches and usually bear teeth on their inner surfaces, and to examine these it is necessary to remove the bones. This is most easily done in the case of the minnows and other small species by lifting the opercle and inserting a small hook behind the gills. In the sunfish and suckers and other larger forms it is best to run a scalpel around them before attempting to remove them. The teeth when removed are usually covered, more or less, with broken tissues, which can be removed by cleaning carefully with a fine-pointed needle, or with a soft brush under water. In case the teeth have been broken off, as frequently happens, the bases can be distinguished. A good hand lens is essential. In native minnows the pharyngeal teeth are in one or two rows, and their number and arrangement is expressed by a formula-thus $1,4-4,2$, meaning that on one side the small, inner row consists of one tooth, and on the opposite of two, while the teeth of the outer row are the same on both sides. The fins are composed of stout spines, or soft rays or af both. In the fin formula the number of spines is expressed by Roman characters, and the rays by the Arabic figures. Thus the formula, "D. X, I4," indicates that the dorsal fin is composed of ten spines and fourteen rays. If the dorsal fin were in two parts the formula would read " $\mathrm{D}$. X-I4." In counting the number of rays the undeveloped rudimentary ones are not usually considered except in the case of the catfish. A little allowance may be made for variation in number of rays. In small specimens where the rays are not always easy to count, a good way to determine the number is to draw the point of a pin forward over the fin near the base of the rays. A good lens is also useful. The dorsal fin is usually referred to in descriptions as simply the dorsal, and other fins in like manner. They are further abbreviated by using D., A., C., V. and P. to stand for dorsal, anal, caudal, ventral and pectoral fins respectively. The scalis are counted along the lateral line (a longitudinal row of scales each with a small pore in most fishes) from behind the opercle to the base of the caudal fin, and the transverse rows are counted from the front 
of the dorsal fin to the lateral line and from the lateral line to the middle of the belly. Thus the formula, "6-45-4," means that there are forty-five scales in a longitudinal row, and that there are six rows above the lateral line and four below it. If the lateral line were absent the formula would read, "45-10." Variations, sometimes considerable, may be looked for in the scale formula. The gill membranes (free folds of skin below the opercles, supported by one or more branchiostegal rays) may be "connected," that is, united together in a fold below the "isthmus" or space between the throat and breast, they may be "joined to the isthmus" along their lower edges, or they may be "free" from the isthmus and from each other. The pre-maxillaries are "protractile" when they are separated in front from the skin of the forehead by a transverse groove, and "not protractile" when such transverse groove is incomplete or wanting. In some fishes, as in the bass and many sunfishes there is a "supplemental maxillary" bone lying along the upper side of the maxillary. In taking body measurements the depth is taken at the deepest place, and the head is measured from point of snout to the end of the opercle, except that in sunfishes the soft flap is not measured. Depth and length of head are compared with the length of the whole body exclusive of the caudal fin. Thus, "head 4 " means that the length of the head is contained four times in the length of the body. The eye is measured to the full width of the orbit.

The writer desires to express his gratitude to the Department of Zoology of the Ohio State University for the use of a seine and other collecting apparatus, to Prof. Herbert Osborn for kindly advice and assistance in many ways, and to the Trustees of the Ohio State Academy of Science for pecuniary aid, through the Emerson McMillin fund, in carrying on the work of seining. Special acknowledgment is also due to Messrs. J. S. Hine, W. R. Rhoades, Chas. Carter, F. L. Landacre, J. H. Pumphrey, S. E. Rasor, Chas. Osburn, and others, who by kindly assistance in various ways have so materially aided in the pursuit of the work. 



\section{THE FISHES OF OHIO.*}

A. Body long and slender, eel-like; skin smooth and slippery, wholly devoid of scales ; no paired fins; no lower jaw; the mouth placed in or near the center of a large, circular and sucker-like disc; a single median nostril ; skeleton cartilaginous.Class: MARSIPOBRANCHII (Cyclostomes).

AA. Body variously developed, scales usually but not always present ; paired fins present ; lower jaw always present ; nostrils never median.-

Class: Pisces (True Fishes).

\section{Class: MARSIPOBRANCHII.}

\section{Order: HYPEROARTII.}

Family: Petromyzonidae (Lampreys).

Key to Genera.

A. Sucker large, and furnished with numerous teeth which are in rows radiating from the mouth; horny plate above the mouth short and provided with 2 or 3 teeth, which are placed close together.-

IснтнуомYZON.

AA. Sucker relatively small, and with few teeth; mouth overhung with a crescentshaped, horny plate, which terminates at each end in a distinct tooth; tongue armed in front with a crescentic, serrated, horny plate.-

LAMPETRA.

\section{Genus : Iснтнуомyzon.}

Ichthyomyzon concolor (Kirtland). SILVER LAMPREY.

Sucking disk large, moderately fringed; teeth strong and nearly uniform; two teeth on supraoral plate; seven in the transverse row below mouth, the remaining teeth arranged in about four concentric circles. Dorsal fin arising midway from snout to end of tail, broadly notched, continuous. with caudal ; anal fin also continuous with caudal. About fifty-two muscular grooves between gills and vent. General color bluish, sometimes blotched with black; a dark blue spot above each gill opening. Length about 12 inches.

This species appears to be distributed throughout the state, though nowhere very common. It ascends small brooks in spring. to breed. McCormick mentions finding females with ripe eggs on May 22, in Vermillion river. The breeding date must be considerably earlier in central Ohio, as Messrs. Parker, Williamson and the writer took young larvæ a couple of inches long in Big Jelloway creek, Knox County, during the latter part of May, I 898. On the same date a large larva seven inches long was taken, so the species must continue in the larval stage something

*It has been thought best to include here also the Lampreys (Marsipobranchii) of Ohio, for the reason that, in the popular idea, a lamprey is a "fish." 
more than a year. One large larva, seven inches in length, showed the following colors: dull yellow, pigmented above with fine, brown specks, giving to the back a brownish cast; this is interrupted in the mid-dorsal line, leaving a yellow, vertebral line; fins yellowish, brightest at base. Young larvæ, two and one-half inches long, were light olive brown, with fine brown specks above; dark around base of anal fin. Eyes very slightly developed. The young larvæ were taken from a mass of sand and mud seined from the bottom of Sawmill Run.

The species was first taken by Dr. Kirtland in Big Miami river, and described by him. He afterward recorded it from the Mahoning and Scioto rivers. Vermillion river, McCormick, I892 ; Big Jelloway creek, Parker, Williamson and Osburn, I898 ; Henshall mentions one which passed through a hydrant in Cincinnati ; and Dr. Jordan says, "I have obtained several specimens with Perch from Lake Erie, both external, feeding on the Perch, and internal, having been devoured by the fish."

\section{Genus: Lampetra..}

Lampetra wilderi (Gage). SMALI, BLACK LAMPREY;

BROOK LAMPREY.

Sucking disk smaller than in the preceding, the fringes longer. Dorsal fin arising midway from snout to end of tail, not continuous with caudal except during breeding season, when it is deeply notched. Below the mouth is a transverse row of blunt, horny teeth, 5 to 9 in number. On each side of the disk is a plate with three bicuspid teeth; supraoral plate with a tooth at either end; remaining teeth. few and weak. About 65 muscular grooves between gills and vent. Color bluish black, lighter on disk and belly. Length 6 to 9 inches.

Although from its range we might expect this species to occur throughout the state, it has, I believe, been recorded for but one locality. Mr. J. B. Parker has observed it to be common on the ripples of small tributaries of Big Jelloway creek, in Knox County, about the middle of April. Four specimens were captured at one dip of an insect net, and specimens taken by him are in the State University collection. The Ammocutes bicolor, or Blind Lamprey, which Kirtland records from the Mahoning river may have been the larva of either this or the preceding species, as the immature forms are so similar as to be almost indistinguishable. 


\title{
Class: PISCES.
}

\section{Sub-Class: Teleostomi ('True Fishes).}

\author{
Artificial Key to the Families of Fishes.
}

\section{Ventral Fins PResent-Abdominal.}

A. Back with an adipose fin behind the single, rayed dorsal fin.

B. Head with barbels about mouth and nostrils, body scaleless; a single spine in each pectoral and in dorsal fin.-

SILURIDA.

BB. Head without barbels ; body scaled.

C. Dorsal, anal and ventral fins each with a small but distinct spine; scales ctenoid.- $\quad$ PERCOPSID $x$.

CC. Dorsal, anal, and ventrals without distinct spine; scales not ctenoid.-

AA. Back without adipose fin.

SALMONID.E.

D. Dorsal fin single, composed of rays, and not preceded by a series of free spines.

E. Tail evidently strongly heterocercal.

F. Body naked; snout with a spatulate blade; mouth wide, without barbels.-

POLYODONTIDE.

FF. Body with scales or bony plates or shields.

G. Body with 5 series of bony shields; mouth inferior, toothless, preceded by four barbels.- ACIPENSERIDAE.

GG. Body scaly.

H. Scales cycloid; a broad, bony, gular plate; dorsal fin many rayed.-

AMIIDE.

HH. Scales ganoid; no gular plate ; dorsal fin short.-

LEPISOSTEIDE.

EE. Tail not evidently heterocercal.

I. Gill membranes broadly joined to the isthmus; head naked; no teeth in jaws.

J. Lower pharyngeal teeth very numerous, in one row like the teeth of a comb.-

CatosTomide.

JJ. Lower pharyngeal teeth few, fewer than 8, in I to 3 rows.-

II. Gill membranes free, not attached to the isthmus.

CIPRINIDA.

K. Head scaly, more or less.

L. Upper jaw not protractile, its lateral margins formed by the maxillaries.

M. Jaws depressed, prolonged ; lateral line present.-

MM. Jaws short; no lateral line.-

LUCIIDE.

UMBRID平.

LL. Upper jaw protractile, its margin formed by premaxil-

KK. Head naked.

laries alone; no lateral line.- POEcIlIIDz.

N. Lateral line well developed; mouth large, teeth all pointed, some of them canine.- Hrodontride.

NN. Lateral line wanting.

O. Mouth small, inferior, toothless; stomach gizzardlike.- Dorosomatidze.

OO. Mouth moderate, terminal ; stomach not gizzardlike.-

Clupeide. 
DD. Dorsal fin not as in D.

P. Dorsal fin single, preceded by free spines; body scaleless.-

GASTEROSTEID.E.

PP. Dorsal fins, two; the first small, compused entirely of spines; body very slender, covered with scales.ATHERINID正.

II. Ventral Fins Present-Thoracic or Sub-Jugular.

A. Body covered with scales.

B. Rays of the ventral fins, I, 5 .

C. Lateral line extending on caudal fin to tip of middle rays.-ScraEnide.

CC. Lateral line not extending beyond base of caudal fin.

D. Pseudobranchiæ or false gills on under side of opercles well developed; head scaled forward to between nostrils.-SERRANIDE.

DD. Pseudobranchiæ wanting or covered by skin.

E. Anal spines, 3 to Io ; body more or less deep and compressed.CENTRARCHID.;.

EE. Anal spines, I or 2 ; body usually elongate.- PERCIDE.

BB. Rays of the ventral fins not I, 5 .

F. Dorsal fin single, with 3 or 4 spines.- APHREDODERID E.

FF. Dorsal fin divided into 2 distinct parts, spines wanting.- GADIDE.

AA. Body naked; dorsal fin with 6 or 7 spines.- COTTID

\section{VENTRAI, FINS ENTIRELY WANTING.}

A. Body long and snake-like; skin cov red with lon $s$ imbedded scales at right angles to each other ; lower jaw projecting. -

ANGUILLID.F.

Series: GanoIDEI.

CHONDROGANOIDEA (The CARTIlaginous GanoIds).

Order: SELACHOSTOMI.

Family: Polyodontide.

Genus: POLYODON.

Polyodon spathula (Walbaum). PADDLE-FISH; SPOON-BILL CAT.

A very peculiar looking fish, recognizable at once by its long, paddleshaped snout, which is about $1 / 3$ the length of the body and is thin and flexible. The eyes are small and placed near the base of the snout; opsrcular flap long, reaching back as far as to the ventral fins. Caudal fin large, forked, the lobes about equal. Color olivaceous, paler below. This singular fish attains a length of 5 or 6 feet, but is of little or no economic importance.

Taken in the Ohio and Muskingum rivers, Kirtland; "one was taken in a pound net (in Lake Erie) near Vermillion in I874," McCormick; "common in the Ohio river," Henshall, I 888 . 


\section{Order: CHONDROSTEI. \\ Family: ACIPENSERIDE.}

Key to Genera.

A. Spiracles present; snout subconic; rows of bony shields distinct throughout; the tail not depressed nor mailed.ACIPENSER

AA. Spiracles obsolete; snout subspatulate; rows of bony shields confluent behind dorsal so that the depressed tail is completely mailed.SCAPHIRHYNCHUS.

\section{Genus: ACIPENSER.}

Acipenser rubicundus Le Sueur. LAKE StURGEON; OHIO STURGEON ; ROCK STURGEON.

Body elongate, terete, tapering towards snout and tail. Snout long and slender in young, becoming more blunt with age. Body covered with large, rough, strongly hooked shields, which become smoother with age. Color dark olive above, sides paler or reddish, with sometimes irregular dark spots. Length 6 feet.

This species occurs both in Lake Erie and the Ohio river. Those from the Ohio, formerly considered as belonging to a separate species, $A$. maculosus, are now regarded as the young of A. rubicundus. "The Ohio river as far as Pittsburg," Rafinesque (Rafinesque made six species out of this and Scaphirhynchus platorynchus, which he included in the same genus); Lake Erie and Ohio river, Kirtland; Lorain County, very common, McCormick, I892; abundant in the Ohio river, Henshall, I888; Lake Erie (west end), Kirsch, 1893.

\section{Genus: ScAphirhynchus.}

\section{Scaphirhynchus platorynchus (Rafinesque)} SHOVELNOSE STURGEON.

Body slender, head broad, becoming suddenly broader just behind the eyes. Snout flat and pointed. The body tapers gradually backward from the head to the tail, the upper lobe of which ends in a long, slender filament. Body protected by five rows of bony shields, which are keeled and hooked. Color olive, paler below. Length 5 feet.

"Very common in the Ohio, but seldom reaching as high as Pittsburg," Rafinesque ; "common in the waters of the Ohio," Kirtland ; "common in the Ohio," Henshall, I 888. 


\section{HOLOS'TEI (The Bony Ganoids).}

\section{Order: RHOMBOGANOIDEA.}

Family: LEPISOSTEIDE.

\section{Genus: LEPISOSTEUS.}

\section{Key to Species.}

A. Large teeth of upper jaw in I row on each side.

B. Beak long and slender, snout more than twice the length of head.- osseus.

BB. Beak shorter and broader, little longer than the rest of the head.-platostomus.

AA. Large teeth of upper jaw in 2 rows on each side; beak short and broad, not longer than rest of head.-

tristochus.

\section{Lepisosteus osseus (Linnaeus). COMnon Gar PIKE;} BILLFISH ; GAR.

Snout at least twice as long as the rest of the head, and quite slender, its least width being contained I $_{5}$ or 20 times in its length. Color olivaceous above, paler below. Young with round, black spots on vertical fins and posterior part of body, these becoming less distinct with age. Very young with black, lateral band. Length 5 feet.

A voracious, good-for-nothing fish, but interesting to the naturalist on account of its structure and habits. A common and widely distributed species, being found in Lake Erie and Ohio river, and in all the larger streams of the state. They are very common in the Scioto river below Columbus, where the river in summer is rotten with filth from the sewers of the city. They have a peculiar habit of lying motionless in schools at the top of the water. Dr. Kirtland records the species for the state as " found in most of the larger tributaries of the Ohio ;"' Lorain County, Lak z and lower part of larger streams,' McCormick, I892; Ohio river and Lake Erie, Henshall, I889; Maumee river, Blanchard river, Auglaize river, Hoaglin creek and Beaver creek, Kirsch, I893; Scioto river at Columbus, Williamson and Osburn, I897; Ohio river at Ironton, John's Creek at Waterloo, Huron river at Milan, and Sandusky Bay, R. C. Osburn, I899; Ohio River at Bellaire, R. C. Osburn, I90o.

\section{Lepisosteus platostomus Rafinesque. SHORT-NOSED GAR.}

Distinguished from $L$. osseus chiefly by the snout, which is only a little Jonger than the rest of the head-never more than $13 / 4$ times the length of 
the head. The snout is also comparatively broader than in $L$. osseus, its least width being contained only 5 or 6 times in its length. Coloration much as in L. osseus.

Rare in Lake Erie and its tributaries, more common in the Ohio and its tributary rivers. Ohio, Miami and Scioto rivers, Rafinesque; Maumee river at Toledo, " a single specimen," Kirsch, I893 ; Lorain county, "very rare," McCormick, I892 ; Sandusky Bay, one specimen, and Ohio river at Ironton, R. C. Osburn, I899.

Lepisosteus tristœchus (Bloch and Schneider). ALLIGATOR GAR.

Snout shorter than in either of the preceding members of this genus, being usually shorter than the head. It is also comparatively much broader, its least width being contained in its length $3^{\mathrm{T} / 2}$ times. Length 8 or ro feet. "A huge, muscular, voracious fish, useless as food, remarkable for its armature of enameled scales."

This species is included on the authority of Dr. Kirtland, who says (Rept. on the Zool. of Ohio, I838): "A specimen is to be seen in the Cincinnati Museum, said to have been taken within the bounds of our state.' Jordan and Evermann (Bull. 47, U. S. Nat1. Mus.) give its range as far as Cincinnati, whether on added evidence I do not know.

\section{Order: CYCLOGANOIDEA. \\ Family: AnIID死. \\ Genus: Amia.}

Amia calva Linnaeus. DogFISH; Bowfin; GRINDLE.

Head $3 \frac{3}{4}$ in length; depth 4 to $4 \frac{1}{2}$; D. 48 ; A. Io to I2 ; V. 7 ; scales ir lateral line 67 ; lateral line nearly median, directed slightly upward at either end. Color dark olive or blackish, paler below; lower jaw usually with round, dark spots; fins somewhat mottled. Male with a round, black spot at base of caudal above, surrounded by a yellowish or orange shade. Length, male 18 inches; female 2 feet.

Lake Erie, Kirtland; Lake Erie and Ohio river, Jordan; Lorain County, "Rare, once in a great while one is brought in from the pounds, and I have taken one in Black river," McCormick, I892; Lake Erie, Henshall; one specimen from the Maumee river at Toledo, Kirsch, I893; Huron river and Sandusky Bay, R. C. Osburn, I899. 


\title{
Series: Teleostei.
}

\section{Order: NEMATOGNATHI.}

\section{Family: Siluride (The Catfishes).}

\author{
Key to Genera.
}

A. Adipose fin, with its posterior margin free.

B. Premaxillary band of teeth truncate behind; not produced backward at the outer angles.

C. Supraoccipital bone continued backward from the nape, its notched tip receiving the bone at base of dorsal spine, so that a continuous bony bridge is formed under the skin; caudal fin forked.- ICTALURUs.

CC. Supraoccipital not reaching as far as dorsal fin, the bony bridge more or less incomplete.- $\quad$ Amerurus.

BB. Premaxillary band of teeth with a lateral backward extension on eacH side; lower jaw projecting.-

I,EPTOPS.

AA. Adipose fin keel-like, adnate to the back.

B. Band of teeth in upper jaw, with a backward extension at its outer posterior angle as in Leptops.- $\quad$ Noturus. .

BB. Band of teeth in upper jaw without backward extension, as in Ameiurus.SCIILHE()IES.

\section{Genus: IcTALURUS. \\ key to Species.}

A. Anal fin very long, its rays 32 to 35 .-

AA. Anal fin shorter, its rays about 26.-

furcatus.

punctatus.

Ictalurus furcatus (Le Sueur). CHUCKLE-HEADED CAT.

Head $4 \frac{1}{2}$; depth 4 in adults to $5 \frac{1}{2}$ in young. Anal fin long, of 32 to 35 rays. Eye small, wholly anterior, the middle of the head being kehind-its posterior margin. Humeral spine not reaching middle of pectoral spine. Color silvery, sometimes spotted with darker. Sometimes reaching a weight of over 40 pounds.

"I have seen one or two specimens taken at Cincinnati," Jordan; "common in the Ohio river," Henshall, I888. Not recorded elsewhere in the State.

\section{Ictalurus punctatus (Rafinesque). CHANNEI, CAT; BLUE CAT; White CaT; Lady CaT.}

Head 4 ; depth 5 ; anal fin of 25 to 30 rays, usually 27 in Ohio specimens. Eye large, the middle point of the length of the head being near its posterior margin. Barbels long, those of the maxillary reaching beyond gill opening. Humeral process long, more than $1 / 2$ the length of pectoral spine. Color light olivaceous, becoming silvery or pale on sides and belly ; the sides usually with distinct round, dark spots, these becoming less distinct with age. Young specimens usually have a gaunt, faded-out, "consumptive" look. It reaches a weight of about 25 pounds. 
Distributed throughout the state, but more abundant in the Ohio and tributaries. Rafinesque records it under the name Pimelodus (Silurus) maculatus, " as far as Pittsburg." Kirtland mentions it under the name Pimelobus coevulescens, as "common to the Ohio and lake waters," and as P. pallidus, "common in the Ohio at Cincinnati." The latter is identical with the former. Abundant in Ohio and Little Miami rivers, Henshall, I888; Lorain County, common, McCormick, I892; Maumee river at Toledo and Grand Rapids, Kirsch, Is93: Muskingum river at McConnellsville, Prof. D. S. Kellicott, I895 ; Franklin County, " common in all larger streams, especially in Big Walnut creek," Williamson and Osburn, I897; Ohio river and Ice creek at Ironton, Wabash river at Celina, R. C. Osburn, I899; Chippewa lake, Ohio river at Bellaire, R. C. Osburn, I9oo.

\section{Genus: Ameiurus.}

\section{Key to Species.}

A. Caudal fin forked.-

lacustris

AA. Caudal fin not forked.

B. Anal fin long, of 24 to 27 rays (counting rudiments).-

BB. Anal fin shorter, of 17 to 22 rays.

C. Lower jaw projecting. Anal rays 20.-

CC. Lower jaw not projecting.

D. Pectoral spines long, 2 to $2 \frac{1}{2}$ in head; anal rays 20 to 23.-nebulosus.

DD. Pectoral spines shorter, $2 \frac{1}{2}$ to 3 in head; anal rays 17 to $19 .-$ melas.

- Ameiurus lacustris (Walbaum). Mississippi CAT; GreaT FORK-TAILED CAT.

Head 4, low, broad and depressed, its upper surface quite flat, its width $\frac{5}{6}$ its length. Depth 5 ; D. I-5; A. 25 to 32 , base of the fin as long as head. Humeral process short, unly a little over $1 / 3$ the length of pectoral spine. Body stouter than in the preceding genus. Caudal fin deeply forked. Color dark olivaceous or slate, growing darker with age ; belly pale, no dark spots on sides. Our largest catfish, said to reach a weight of $\mathrm{I}_{5} \mathrm{O}$ pounds or more.

In Ohio this species is well distributed, being found in the lake, Ohio river and larger streams. Kirtland does not record this species, probably confusing it with his Pimelobus coerulescens (Ictalurus punctatus). Common in the Ohio river, Henshall, I888; Lorain County, common in the lake and lower parts of the rivers, McCormick, I892; Franklin County, two specimens taken in Big Darby creek; one of these, a female weighing $4 \frac{1}{2}$ pounds, contained eggs, June 2I, I897, Williamson and Osburn. 
Ameiurus natalis (Le Sueur). YELLOW CAT.

Head broad and short; upper jaw slightly projecting. Body stoutish; the back low, not arched. Anal fin long, its base contained in length of body $3^{T / 2}$ to $3^{1 / 4}$ times; its rays 24 to 27 . Color usually brownish or yellowish, sometimes black; belly pale or yellowish. Length about a foot. Ohio specimens seem to fall into the nominal variety cupreus, as indicated by the longer upper jaw.

This is a common species in most parts of Ohio, occurring in nearly all streams and lakes. "The yellow catfish I have only seen in the Cincinnati markets, where it is comparatively rare," Kirtland ; Lake Erie, Henshall, I889 ; Lorain County, "common in the ponds, streams and lake," McCormick, I892; Maumee river at Antwerp, Defiance, Grand Rapids and Waterville, Tiffin river at Brunersburg, Sugar creek at Lima, Lost creek at Lima, Blanchard river at Findlay and Ottawa, Beaver creek at Grand Rapids, "seemingly scarce at all of these points," Kirsch, I893; Franklin County, Scioto river, Olentangy river, Big Walnut, Little Walnut and Darby creeks, and Hell Branch, Williamson and Osburn, I897 ; Ohio river at Ironton, John's creek at Water1oo, Huron river at Milan, Ashtabula creek at Ashtabula, IVabash river at Celina, Stillwater and Wolf creeks at Dayton, North Fork of Licking river at Newark, R. C. Osburn, I899; Chippewa laḳe, Summit lake, Licking reservoir, R. C. Osburn, Igoo.

\section{Ameiurus vulgaris (Thompson). LONG-JAWED CATFISH.}

Head $3 \frac{1}{2}$ to 4 , a little longer than broad, considerably narrowed forward when viewed from above, lower jaw distinctly projecting. Body somewhat elongate and compressed, the back somewhat elevated. Anal rays 20. Color dark brownish or black, becoming white rather abruptly on the belly. Length I8 inches.

The Long Jawed Catfish is not common in Ohio, but seems to be widely distributed. Jordan mentions it as "taken in Lake Erie and occasionally in the Ohio"' ; Henshall in 1889 records it for Lake Erie; Lorain County, "Martin's run, only one recorded," McCormick, I892 ; two specimens from the Ohio canal at Columbus, Williamson and Osburn, I897 ; Pippin lake, R. C. Osburn, I900. 


\section{Ameiurus nebulosus (Le Sueur). CoMmon BuLL-HEAd ; \\ HORNED POUT.}

Head broad and flattened, upper jaw noticeably the longer. Body rather elongate, depth 4 to $4 \frac{1}{2}$. Anal fin with 20 to 22 rays, its base contained 4 times in length of body. Humeral process more than $1 / 2$ the length of the rather long pectoral spine. Color dark brown or brownish yellow, usually somewhat clouded, sometimes nearly black. Length 18 inches.

A very common species in the lake and its tributaries, less common in the Ohio river drainage, but found in all larger streams. "Occasionally seen in the Cincinnati markets," Kirtland; Lake Erie, Henshall, I889 ; Lorain County, "common in all streams," McCormick, I892; Maumee river at Cecil and Waterville, Fish creek at Edgerton, St. Mary's river at St. Mary's, Gordon and Lost creeks near Cecil, Tiffin river at West Unity and Brunersburg, Auglaize river at Wapakoneta, Cloverdale, Oakmood and Defiance, Sugar creek at Clorerdale and Lima, Lost creek at Lima, Blanchard river at Findlay and Cloverdale, Hoaglin creek at Oakland, Kirsch, I893; Franklin County, Scioto river, Olentangy river, Mason's run, Big Walnut, Little Walnut, Big Darby and Alum creeks, Williamson \& Osburn, I897; Huron river at Milan, Sandusky Bay, Ashtabula creek at Ashtabula, R. C. Osburn, I899; Pippin lake, Summit lake, R. C. Osburn, I900.

\section{Ameiurus melas (Rafinesque). BLACK BULL-HEAD.}

Body stout, short and deep, back high, the profile nearly straight to base of dorsal fin. Head broad, rounded in front, jaws about equal. Pectoral spine short, its length contained $2 \frac{1}{2}$ to 3 times in length of head. Anal fin short and deep, its base $4 \frac{1}{2}$ to 5 in length of body, rays $I 7$ to 19 , the light colored rays contrasting sharply with the dark membranes. Color almost black, sometimes brownish or yellowish, the belly pale or yellowish. This species shares with the three next preceding the name of Bull-head, the ordinary fisherman not drawing very fine distinctions in regard to species.

The Black Bull-head is the most abundant species of catfish in the state, found in nearly all streams and ponds of whatever size, and especially in the Ohio river drainage. It is less abundant in the lake drainage. It is a mud loving species and is less likely to be found in clear, swift streams than in muddy, stagnant bayous. A. xanthocephalus Rafinesque is now recorded as synonymous 
with $A$. melas. Recorded by Kirtland as $A$. xanthocephalus, and by Jordan as $A$. melas and xanthocephalus. "Very common in Ohio and Little Miami rivers and Mill creek," Henshall, I888; Lorain County, "common in all streams and ponds," McCormick, I892; Maumee river at Cecil and St. Mary's river at Rockford, Kirsch, I893 ; Franklin County, in nearly all streams, Williamson and Osburn, I897; Big Jelloway creek at Howard, Parker, Williamson and Osburn, I898; Ohio river at Ironton, Huron river at Milan, Wabash river at Celina, Stillwater and Wolf creeks at Dayton, North Fork of Licking river at Newark, R. C. Osburn, I899 ; Sandusky, Prof. D. S. Kellicott, Williamson and Osburn, I896; Niggermill run at Salem, E. B. Williamson, I 900 ; Sandusky bay at " Black Channel," Breakneck creek and Cuyahoga river near Kent, and Licking reservoir, R. C. Osburn, I900; June 22 is given as a breeding date by Williamson and Osburn.

\section{Genus: LEPTOPS.}

\section{Leptops olivaris (Rafinesque). MUD CAT.}

Body slender, depressed forward, the head extremely flat, the lower jaw the longer. Dorsal spine very weak, only $1 / 2$ the height of the fin ; caudal fin slightly emarginate; anal short, its base about $\frac{1}{6}$ the length of body, its rays 12 to 15 . Yellowish, much mottled with brown and greenish, whitish below. Size large, reaching a weight of 50 to 75 pounds.

Jordan says, "This species abounds in the Ohio river and its larger tributaries," but it is probably common nowhere in Ohio except in the southwestern part of the state. Henshall records it for White Oak creek and the Ohio river, I889; and in 1892 McCormick mentions the occurrence in Lake Erie, Lorain County, as "quite rare; I have seen but one specimen fresh, though I have noticed heads on the beach."

\section{Genus: Noturus.}

Noturus flavus Rafinesque. Yellow STONE CAT.

Head broad and flat, much depressed, 4 in length of body. Body terete, tail compressed. Soft dorsal fin keel-like, separated from caudal by a deep notch. Dorsal spine very short, only $1 / 2$ as long as pectoral spine ; caudal rounded; anal short, its rays about I6. Brownish yellow, varying into bluish or blackish. Length I foot. 
Widely distributed and generally common in suitable localities. It is found most abundantly on stony ripples of the larger streams, and on sandy and gravelly bottoms of rivers and lakes. "Occasionally found beneath stones in the Mahoning river," Kirtland; "much more abundant in the Ohio and its immediate tributaries than in the streams of the interior," Jordan ; " abundant in Little Miami river, Mill creek and nearly all streams" (Hamilton County), Hensha11, I888; Lorain County, "larger streams and the lake," McCormick. I 892 ; Maumee river at Defiance, Grand Rapids and Waterville, Fish creek at Edgerton, St. Mary's river at Rockford, Auglaize river at Cloverdale and Defiance, Blanchard river at Ottawa, Hoaglin creek at Oakland, and Blanchard river and Sugar creek at Cloverdale, Kirsch,' I 893 ; Franklin County, "abundant in all larger streams, Scioto and Olentangy rivers, Big Walnut, Little Walnut, Alum, Big and Little Darby creeks, Black Lick and Hell Branch,' Williamson and Osburn, I897; Knox County, Big Jelloway creek, Parker, Williamson and Osburn, I8s8 ; John's creek at Waterloo, Huron river at Milan, North Fork of Licking river at Newark, R. C. Osburn, I899; Lake Erie at Sandusky, frequently thrown up dead on the beach by the waves; not noticed in Sandusky bay, Wheeling creek at Bridgeport, Ohio river at Bellaire, R. C. Osburn, I900.

\section{Genus: ScHILBEODES. \\ Key to Species.}

A. Pectoral spine entire or grooved behind, never retrcrsely serrate; adipose fin high and continuous, not separated by a notch from the caudal.- gyrinus.

AA. Pectoral spine distinctly serrate behind.

B. Adipose fin nearly or quite free from caudal; color nearly plain brownish, saddle-like blotches faint, everywhere pigmented with fine dots; anterior edge of pectoral spine retrorsely serrate.eieutherus.

BB. Adipose fin not quite free from caudal ; color much variegated, back with distinct saddle-like blotches; pectoral spine strong, its anterior edge with few serrations.miurus.

\section{Schilbeodes gyrinus (Mitchill). Chubby Stone Cat; TADPOLE CAT.}

Head large, broad and depressed, $3 \frac{1}{2}$ to 4 in length; mouth wide, jaws :about equal. Body short and stout, pot-bellied, shaped much like a tadpole. Caudal peduncle comparatively long and compressed. Pectoral spine not

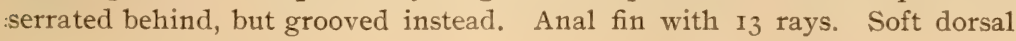


continuous with caudal, scarcely notched. Color yellowish brown or brownish olive, nearly uniform; a distinct narrow, black line along lateral line. Length 5 inches.

Rather irregularly distributed, but common in suitable localities. Dr. Jordan (Ohio Rept.) says of this species and S. miurus that "their habits are similar, they are usually found together and are about equally abundant in Ohio,' but in the writer's experience $S$. miurus has been found much more generally distributed, occurring in the open water of streams, usually on gravelly or stony bottom, while gyrinus seems to prefer the quiet of lakes and ponds, and in the course of several years collecting the two species have never been taken together. $S$. gyrinus was observed by Prof. D. S. Kellicott, Mr. E. B. Williamson and the writer to be common among the decaying vegetation in shallow water in Sandusky Bay in I896; "Ross lake," Henshall, I889; Lorain County, "Common on mud banks in the lower parts of streams entering the lake,' McCormick, I892; Maumee river at 'Toledo, St. Mary's river at St. Mary's, “everywhere scarce,' Kirsch, 1893 ; Franklin County, Mason's run and Big Darby creek, rare, Williamson and Osburn, I897 ; Sandusky Bay, R. C. Osburn, I 899 ; Summit lake, Licking reservoir, R. C. Osburn, I900.

\section{Schilbeodes eleutherus (Jordan).}

Head broad and flat, much depressed, narrowed anteriorly, 33/4 in body ; upper jaw much longer than the lower, which is included. Body much of the same form as that of $S$. miurus, but with the back somewhat higher; depth $4 \frac{1}{2}$ in length. Soft dorsal free from caudal, or only very slightly connected. Color nearly uniform brown above, lighter below, flecked everywhere except on middle of belly, with black dots. Distinguished from $S$. miurus, which it most nearly resembles, by the free adipose fin, the longer upper jaw and the absence of distinct, black, saddle-like blotches on the back. Length 4 inches.

I know of but one specimen of this very rare species taken within the limits of the state. This was taken in Big Walnut creek, Franklin County, by Mr. E. B. Williamson and the writer, June 25, I897. 
Schilbeodes miurus (Jordan). CROSS-BARRED STONE CAT.

Head very much depressed, rounded anteriorly, 33/4 in length; upper jaw longer but not so much so as in the preceding species. Depth about 5 in length; back scarcely elevated; adipose fin connected with caudal, but more or less deeply notched. Conspicuously mottled with gray and blackish, with 3 or 4 definite black blotches across the back. Length, 4 inches.

A rather common and widely distributed species. Ohio river at Raccoon I., Henshall, I889; Lorain County, quite rare, Vermillion and Black rivers, McCormick, I892; Maumee river at Antwerp, St. Joseph river at Edgerton, St. Mary's river at Rockford, Tiffin river at West Unity and Brunersburg, and Auglaize river at Cloverdale, Oakwood and Defiance, "In an old mill race which empties into Tiffin river near West U'nity large numbers were caught, common in Hoaglin creek near Oakwood, rather scarce at all other points,' Kirsch, I893 ; Franklin County, generally common, abundant in Big Walnut, taken also in Scioto river, Olentangy river, Black Lick, Little Walnut, Big Darby and Alum creeks, Williamson and Osburn, I897; Ohio river at Ironton, John's creek at Waterloo, Sandusky Bay, Ashtabula creek at Ashtabula, Wabash river at Celina, North Fork of Licking river at Newark, R. C. Osburn, I899; Ohio river at Bellaire, R. C. Osburn, I900. Females were observed with ripe eggs from June 25 to July 6, I897, by Mr. Williamson and the writer. 


\title{
Order: PLECTOSPONDYLI.
}

\author{
Sub-Order: Eventognathi. \\ Family: CAтоsтоміd死 (The Suckers).
}

Key to Genera.

A. Dorsal fin elongate, developed rays 25 to 50 , air bladder in 2 parts.

B. Fontanelle present, body ovate, scales large.

C. Mouth large, more or less terminal, protractile forward; pharyngeal bones and teeth moderate, large species of dark color.- Ictiobus.

CC. Mouth smaller, inferior, protractile downward; pharyngeal bones narrow, the teeth thin and weak; smaller species, pale in color.-

CARPIODES.

BB. Fontanelle obliterated by union of parietal bones; body elongate; scales rather small; lips thick and papillose.- CYcLEPTUS.

AA. Dorsal fin short, to to 18 developed rays,

D. Air bladder in 2 parts.

E. Lateral line present, complete and continuous; scales small, more than 50 in lateral line.- Catostomus.

EE. Lateral line interrupted or wanting, scales large, less than 50 in lat. line. F. Lateral line entirely wanting.- ERIMYzoN.

FF. Lateral line more or less developed, especially in the adult.--

MINYTREMA.

DD. Air bladder in 3 parts; scales large; lateral line complete

G. Mouth normal, the lower lip entire or merely lobed, the upper lip protractile.

H. Pharyngeal bones moderate, the teeth compressed, not molar-like, increasing in size gradually downward.Moxostoma.

HH. Pharyngeal bones very strong, the lower teeth very much enlarged, crlindrical and truncate, molar-like.- PLACOPHARYNX.

GG. Mouth singular, the upper lip not protractile, greatly enlarged, the lower lip developed as two separate lobes.-

IAGOCHILA.

\section{Genus: Ictiobus.}

\section{Key to Species.}

A. Mouth large, terminal, protractile forward; lips very thin, lower pharyngeals and teeth weak.-

cyprinella.

AA. Mouth smaller, more or less inferior, and with thicker lips; pharyngeal bones stronger; the teeth comparatively coarse and large.

B. Back scarcely elevated, depth 3 to $3^{1 / 4}$ in length.-

BB. Back elevated and compressed, depth $2 \frac{1}{2}$ to $23 / 4$. -

urus bubalus.

Ictiobus cyprinella (Cuvier and Valenciennes). Common BuFFalo Fish; RED-MOUTHED BUFFALO.

Head very large and thick, $3 \frac{1}{2}$ in length; depth $21 / 2$ to $3 \frac{1}{2}$. Developed rays of dorsal fin 27 to 29 ; anal 9; ventrals ro. Scales $7-37$ to $4 \mathrm{I}-6$. Body robust, moderately compressed, the outline somewhat elliptical, but the back rather more curved than the belly. Opercular apparatus very strong, the operculum forming nearly $1 / 2$ the length of the head. Color dull brownish olive, not silvery, fins dusky. Length nearly 3 feet. 
According to Jordan, the Red-mouthed Buffalo Fish abounds in the Ohio river and its larger tributaries, and Henshall reports it "very common in Ohio river." Not reported for any other locality.

Ictiobus urus (Agassiz). MONGREI, BUFFALO; RAZOR-BACKED BUFFALO.

Head very stout, strongly transversely convex, thicker, larger and less pointed than in $I$. bubalus, about 4 in length. Eye about equal to snout, $5 \frac{1}{2}$ in head, much smaller than in $I$. bubalus. Mouth large, considerably oblique, approaching that of 1 . cyprinella. Body much less elevated and compressed than in $I$. bubalus, the back not at all carinated; 3 to $3 \frac{1}{4}$ in length. D. 30 ; A. IO ; scales $8-4 \mathrm{I}-7$. Longest ray of dorsal scarcely $1 / 2$ the length of base of fin ; anal rounded. Colors very dark, fins all black. " Not always separable from $I$. cyprinella, and perhaps not really different."

Ohio river at Cincinnati, Henshall, I889. Not mentioned by any other collector.

\section{Ictiobus bubalus (Rafinesque). BUFFALO FISH; SMALL-MOUTHED BUFFalo; RAZOR-Back; SUCKer-Mouthed BuFfalo.}

Head moderate, triangular in outline when viewed from the side, 4 in length, mouth quite small: Body considerably elevated and compressed above; the dorsal region sub-carinate; the belly thicker; depth $2 \frac{1}{4}$ to $23 / 4$. Highest dorsal ray reaching much beyond middle of fin; D. 29; A. IO; V. Io; scales 8-39-6. Color brownish olive, paler below, the lower fins slightly dusky. Length 30 inches.

Recorded by Rafinesque for the Ohio, " as far as Pittsburg." Also recorded for the state by Kirtland. "Abundant in the Ohio river," Henshall; I888. Not recorded for any other point of the state.

\section{Genus: CARPIODES.}

\section{Key to Species.}

A. Body sub-fusiform, depth about 3 in length. Dorsal with about 30 rays.- carpio.

AA. Body ovate oblong, the back eleva ed, depth about $2 \frac{1}{2}$ in length.

B. Lips thin, silvery white, the halves meeting in a wide angle.

C. Head large, snout blunt; eye large, $3 \frac{1}{2}$ to $4 .-$ difformis.

CC. Head small and pointed, the snout projecting, eye small, 5 to $5 \frac{1}{2}$ in head.-

thompsoni.

BB. Lips full, thick, reddish in life, the halves of lower lip mseting in an acute angle.-

velifer.

Carpiodes carpio (Rafinesque). BIG CARP SUCKER.

Head comparatively short, 4 to 5 in body. Body more fusiform than in others of the genus, compressed, but not much arched, depth $2 \frac{2}{3}$ to 3 . 
Anterior rays of dorsal short, much thickened and osseus at base, especially in adults, the longest ray a little more than $1 / 2$ the base of the fin, which consists of 30 rays; caudal moderately forked. Eye medium, anterior, $4 \frac{1}{2}$ in head. Muzzle short, but projecting beyond mouth. 36 scales in lateral line.

Limited in its distribution to the Ohio and its larger tributaries. "The commonest species of its genus in the Ohio river, and it is often found in the streams of the interior,' Jordan. Very abundant in the Ohio river, Henshall, I888; Ohio river at Bellaire, R. C. Osburn, I9oo.

\section{Carpiodes difformis Cope.}

Snout very blunt, the maxillary reaching to front of pupil. Nostrils very near tip of snout. Lips thin, silvery colored in life, the lower $\Omega$-shaped. Head $4 \frac{1}{4}$ in body; depth $21 / 4$ to $23 / 4$, the back considerably elevated. Eye quite large, $3 \frac{1}{2}$ to 4 in head. D. 24 , its first rays very high; A. 8; V. 9 ; scales, 6-35-4.

Recorded for the state by Jordan, under the name of $C$. cutisanserinus (Cope), as " abundant in the Ohio." C. cutisanserinus is now regarded as identical with $C$. difformis. "Abundant in Ohio river, young common in Little Miami river,' Henshall, I888. Klippart, in his first report, says of this species, that it "abounds in Lake Erie, but this must be a mistake, probably in regard to the species, as $C$. difformis is not, I believe, known to occur in the St. Lawrence System."

\section{Carpiodes thompsoni Agassiz. LAKE CARP.}

Body stout, short, the back much elevated, depth $2 \frac{1}{2}$ in length. Head small, 4 to $4 \frac{1}{2}$ in length, the snout pointed; lips thin, white, meeting at a wide angle. Eye small, 5 to $5 \frac{1}{2}$ in head. Tip of lower jaw much in advance of nostrils ; maxillary reaching line of orbit. Dorsal of about 27 rays, arising about midway from snout to base of caudal, its anterior rays high, $2 / 3$ as long as base of fin. A. 7 ; V. IO; scales rather closely imbricated, 8-39 to 40-6.

"Abundant in Lake Erie. I have examined many specimens from Sandusky Bay," Jordan; Lake Erie, Henshall, I889; Lorain County, " not very common," McCormick, I892 ; Lake Erie at Toledo, Jordan and Evermann (Bull. 47, U. S. Nat'1. Mus.). 
Carpiodes velifer (Rafinesque). QUILI, BACK; SPEARFISH.

Head $3 \frac{3}{4}$ to 4 ; lips thick, full, flesh-colored in life, the halves of the lower meeting at an acute angle; muzzle projecting, conic ; eye 4 to 5 in head. Back much arched; depth $2 \frac{1}{2}$ to 3. Dorsal fin of about 27 rays, the anterior rays very long and filamentous, sometimes as long as the base of the fin. Caudal deeply forked, its lobes slender, the upper lobe the longer. Scales 7-35-5.

Recorded by Rafinesque for the Ohio river as far as Pittsburg. "Quite common in Ohio river, young ones common in Little Miami river and tributaries," Henshall, I888; Maumee river at Antwerp, Defiance, Grand Rapids and Toledo, Tiffin river at Brunersburg, Auglaize river at Cloverdale, Oakwood and Defiance, Blanchard river at Ottawa and Cloverdale, Hoaglin creek near Oakland, Beaver creek at Grand Rapids, "rather common at all these points,' Kirsch, I893 ; Scioto river, Scioto Big Run, Mason's Run and Hell Branch, Williamson and Osburn, I897; Scioto river at Ironton, Wabash river at Celina, Wolf creek near Dayton, North Fork of Licking river at Newark, R. C. Osburn, I899; Breakneck creek and Cuyahoga river near Kent, Chippewa lake, Wheeling creek at Bridgeport, Ohio river and McMahon's Run at Bellaire, R. C. Osburn, I9oo.

\section{Cycleptus elongatus (Le Sueur). BLACK HORSE; MISSOURI SUCKER.}

Depth 4 to 5 ; head 6 to $8 \mathrm{r} / 2$; eye small, 6 to 7 in head. D. 30 , its longest ray a little longer than head; A. 7 or 8 ; scales $9-56-7$. Color very dark, males in spring almost black. Length $2 \frac{1}{2}$ feet.

A pparently confined in this state to the Ohio river. "As far as Pittsburg,' Rafinesque. Recorded for the Ohio by Kirtland and by Jordan, and Henshall in I 888 mentions it as "not uncommon in the Ohio river. 


\section{Genus: Catostomus.}

Key to Species.

A. Head transversely convex above, the orbital rim not elevated, scales in lateral line 60 or more.

B. Scales in lateral line about roo.-

BB. Scales in lateral line 64 to 70 .-

catostomus.

AA. Head broad, depressed, and transversely convex between the orbits; scales in lateral line, 48 to 55 .

nigricans.

Catostomus catostomus (Forster). NORTHERN SUCKER.

This species can at once be distinguished from the others of the genus occurring in Ohio, by the great number of scales in the lateral line, 95 to II.4. About 29 cross rows between dorsal and ventrals. Head broad above, pointed in front; snout a little longer than remainder of head and much overhanging the mouth. Body rather slender and somewhat terete. D. IO; A. 7 . Color, above, smoky gray; below, white. Length $2 \frac{1}{2}$ feet.

This species is one of northern distribution, probably not occuring in the tributaries of the Ohio. "Quite abundant in Lake Erie,' Jordan (Ohio Rept.), I878; Lake Erie, Henshall, I889.

\section{Catostomus commersonii (Lacepede). COMMON SUCKER;} FINE-SCALED SUCKER.

Head rather conical, 4\% $1 / 4$ in length of body, flattish above, but not concave between the eyes. Body moderately stout, terete or sub-terete, becoming heavier at the shoulders with age, depth 4 to 5 in length. D. II or I2; scales small, ro-64 to 70-9. Color olivaceous, tending toward blackish on back and lateral line. Length 18 inches.

One of the commonest species in the state, found in abundance in nearly every stream. Recorded for the state by Kirtland for the Big Miami, and small brooks of northern Ohio; "Swarming in every pond and stream in Ohio," Jordan (Ohio Rept.); Hamilton County, "Everywhere abundant," Henshall, I888 ; Lorain County, "Very common in all our waters," McCormick, I892 ; recorded by Kirsch for nearly every locality seined in the Maumee River System, I893; taken by Mr. Williamson and myself in every stream in Franklin County, I897; in every stream of the Big Jelloway Creek System in Knox County, Parker, Williamson and Osburn, I898; taken by myself in I899, at the following places: Ohio river and Ice creek at 
Ironton, John's creek at W'aterloo, Huron river at Milan, Ashtabula creek at Ashtabula, Wrabash river at Celina, Stillwater and II'olf creeks near Dayton, and North Fork of Licking river at Newark; and in Igoo in the Cuyahoga river at Hawkins, Breakneck creek near Kent, Chipperva lake, Grand river at Painesville, Chagrin river at Willoughby, Wheeling creek at Bridgeport, Ohio river and McMahon's Run at Bellaire, and Licking reservoir.

Catostomus nigricans Le Sueur. HOG SUCKER; STONE ROLLER.

Head large, concave between the eyes, 4\%/4 in length. Body nearly terete, depth $4 \frac{1}{2}$ to 5 . D. Io or II ; scales 48 to 55 in lateral line. Color, olive, becoming brownish on the back, which is crossed by several dark, irregular blotches; belly white. Length 2 feet.

This Sucker is very widely distributed over the state, being found in all suitable localities. Its especial haunts are clear, stony ripples and rock-bottomed pools. Not taken in lakes. Kirtland records it as two species, Hypentelium macropterum and Catostomus nigrans; "extremely abundant in every running stream in Ohio," Jordan (Ohio Rept.); Hamilton County, "everywhere abundant," Henshall, I888; Lorain County, McCormick, I892; Kirsch, I893, records it for the streams at nearly all points investigated in the Maumee River System, " none taken in the lakes"'; Franklin County, Scioto river, Olentangy river, Scioto Big Run, Grant's Run, Big Walnut creek, Rocky Fork, Black Lick, Alum creek, Big and Little Darby creeks and Hell Branch, Williamson and Osburn, I897; every stream in the Big Jelloway Creek System, Parker, Williamson and Osburn, I898; Ohio river and Ice creek at Ironton, John's creek at Water1oo, Huron river at Milan, Ashtabula creek at Ashtabula, Wabash river at Celina, Stillwater and Wolf creeks near Dayton and North Fork of Licking river at Newark, R. C. Osburn, I899; Cuyahoga river at Hawkins, Grand river at Painesrille, Chagrin river at Willoughby, Wheeling creek at Bridgeport, Ohio river and McMahon's creek at Bellaire, and the outlet of Licking reservoir into Licking river, R. C. Osburn, Igoo. 


\section{Genus: ERIMYzon.}

\section{Erimyzon sucetta oblongus (Mitchell). SWEET SUCKE, ; CHub Sucker.}

Head 4 to $4^{\mathrm{I} / 4}$ in length ; snout not projecting; eye $4^{\mathrm{I} / 4}$ to $4^{3 / 4}$ in head. Body stout, compressed; depth in adults about 3 , but younger specimens. much more slender; back arched, old specimens becoming quite gibbous at the nape. Lateral line entirely wanting. Scales about 40, closely imbricated and somewhat crowded anteriorly, sometimes showing irregularities of arrangement. Length ro inches. Color varying with age, in adults brown or brownish olive above, with a tendency to brassy on sides and belly; younger specimens are plain olivaceous, occasionally bright, "gold-fish yellow" ; very young with a distinct, black lateral band, which breaks up into blotches a little later. Ohio specimens show some variations between the typical $E$. sucetta and the variety oblongus, but seem to agree more closely with the variety than with the typical form.

The Chub Sucker, or Sweet Sucker, is widely distributed over the state, but its occurrence is irregular. At some points it is an abundant species, at others rare. "Common in Little Miami and Ohio rivers," Henshall, I888; " not common, I have taken a few in the lower part of Beaver creek," McCormick, I892 ; Maumee river at Toledo, St. Joseph river at Edgerton, St. Mary's river at St. Mary's, Tiffin river at West Unity, Lost and Gordon creeks near Cecil, Kirsch, I893; Franklin County, Scioto river, Scioto Big Run, Grant's Run, Big Darby, Little Darby and Hell Branch, Osburn and Williamson, I897; Ohio river at Ironton, Wabash river at Celina, Stillwater and Wolf creeks near Dayton, R. C. Osburn, I899; Licking reservoir, E. B. Williamson ; Sandusky Bay, very common in Black Channel, Grand river at Painesville, Chagrin river at Willoughby, Wheeling creek at Bridgeport, and Ohio river and McMahon creek at Bellaire, R. C. Osburn, I900.

\section{Genus: MiNYTrema.}

Minytrema melanops (Rafinesque). Winter Sucker; SPOTTED Sucker; STRIPED SUCKER.

Head 4\%1/4; snout round, a trifle projecting. Body elongate, somewhat terete, back somewhat arched in front of dorsal fin; depth about 4. D. 12 ; A. 7. Scales about 46. Lateral line wanting in young, present but more or less interrupted in adults. Coloration dusky olive above, each scale with a more or less distinct black spot at its base, these forming rows along the rows of scales. Length about I8 inches. 
Not usually a common specics, though widely distributed. Recorded by Kirtland, I838; Hamilton County, Little Miami and tributaries, Henshall, I888; Lorain County, "Rare, Vermillion river and Beaver creek," McCormick, I892; Maumee river at Grand Rapids, St. Joseph river at Edgerton, Fish creek at Edgerton, St. Mary's river at St. Mary's and Rockford, Auglaize river at Wapakoneta and Cloverdale, Blanchard river at Findlay, Kirsch, I893; Franklin County, Scioto river, Olentangy river, Black Lick, Little Walnut and Big Darby, Williamson and Osburn, I897; Stillwater creek near Dayton, and Wabash river near Celina, R. C. Osburn, I899. At the latter place, in a series of pools formed by the outlet of St. Mary's reservoir, the species was taken in abundance, the only time I have ever taken more than a few individuals in one locality.

\section{Genus: Moxostoma.}

\section{Key to Species.}

A. Dorsal fin of 15 to 18 rays; lower lip V-shaped.-

anisurum.

AA. Dorsal fin of less than 15 rays; lower lip truncate behind, not evidently V-shaped. B. Head rather large, 4 to nearly 5 in length, snout little projecting.-aureolum.

BB. Head small and conic, about 51/4 in length, the snout much projecting beyond the small mouth.breviceps.

Moxostoma anisurum (Rafinesque). WHITE-NOSED SUCKER.

Head short and broad, flattened above, $3^{2 / 3}$ to $4 \frac{1}{4}$ in length, eye midway in head, 4 to 5 in its length. Body compressed; back high, considerably more arched than in $M$, aureolum; depth $3^{1 / 2}$ in length. Fins all large. Color bright olivaceous to smoky above, white or silvery on sides and belly. Most easily distinguished from other species of the genus occurring in Ohio, by the long dorsal fin, containing from I5 to 18 rays.

This species is found in both the Lake and Ohio river drainage, but is not usually very common, and is confined to the larger streams. Ohio river, "as far as Pittsburg," Rafinesque. Given by Jordan (Ohio Rept.) as three species-M. anisurum, of which he says, "I have seen a few specimens, obtained in the Cincinnati market"; $M$. velatum, "frequently taken in the Ohio river and its tributaries," and M. carpio, from Lake Errie and the Ohio at Cincinnati and Marietta. These three are now regarded as synonymous (See Bull. 47, U. S. Nat1. Mus.). Hamilton County, 
not uncommon in Ohio river, Henshall, I888; Lorain County, McCormick, 1892; Maumee river at Antwerp, Defiance and Toledo; Tiffin river at West Unity and Brunersburg, Auglaize river at Cloverdale, Oakwood and Defiance; Blanchard river at. Ottawa, Hoaglin creek near Oakwood, Beaver creek at Grand Rapids, Kirsch, I893; Franklin County, Scioto river, Olentangy river and Alum creek, Williamson and Osburn, I897; Ohio river at Ironton, Huron river at Milan, R. C. Osburn, I899; Ohio river at Bellaire, Licking reservoir, R. C. Osburn; I9oo.

\section{Moxostoma aureolum (Le Sueur). RED-HORSE; MULLET; WHITE SUCKER.}

Head 4 to 5 , flattened above ; snout slightly projecting ; eye $4 \frac{3}{4}$ in head. Body rather stout, somewhat compressed; back, little elevated; depth 4 in length. D. I3. or more rarely I2 or $x 4 ;$ A. 7 ; scales about 45 . Color olivaceous above, sides silvery; lower fins reddish, especially during the breeding season.

Until very recent years this has been recorded as two species, the short-headed, small-mouthed form as $M$. aureolum, and the more ordinary form as $M$. macrolepidotum duquesnii (Le Sueur). This matter is cleared up by Jordan and Evermann (Bull. 47, U. S. Nat1. Mus.). It is very probable that some collectors have confused the short-headed form with $M$. breviceps (Cope), as I can find no record of $M$. breviceps for Ohio in any paper preceding Bull. 47, U. S. Nat1. Mus., in which it is recorded as abundant in some portions of the state. However, as I have no direct evidence of any such error, I include all records for $M$. aureolum and $M$. macrolepidotum duquesnii under $M$. aureolum. Ohio river, " as far as Pittsburg," Rafinesque ; recorded for the state by Kirtland as Catostomus aureolus, C. Duquesnii and C. erythurus; Hamilton County, "abundant in all streams explored," Lake Erie, Hensha11, I888-89; Lorain County, McCormick, I892 : Maumee river at Defiance, Grand Rapids and Waterville, St. Mary's river at Rockford, Auglaize river at Oakwood, Sugar creek at Lima, St. Joseph river at Edgerton, west end of Lake Erie, Kirsch, I893; Franklin County, "abundant, taken in all but the smallest streams," Williamson and Osburn, I897 ; Knox County, Big Jelloway creek system, "abundant, the young fry 
ascending eren the smallest brooks, " Nay 26 given as a breeding date, Parker, Williamson and Osburn, IS98; Ohio river and Ice creek at Ironton, John's creek at Waterloo, Huron river at Milan, Sandusky Bay, Ashtabula creek at Ashtabula, Wabash river at Celina, Stillwater and Wolf creeks near Dayton, North Fork of Licking river at Newark, R. C. Osburn, I899; Niggermill Run at Salem, E. B. Williamson, I900 ; Cuyahoga river at Hawkins, Grand river at Painesrille, Chagrin river at Willoughby, Wheeling creek at Bridgeport, Ohio river and McMahon creek at Wheeling, Licking reservoir, R. C. Osburn, I9oo.

\section{Moxostoma breviceps (Cope).}

Form of a Coregonus, with deep, compressed body, small head, and a conic snout, which overhangs the very small mouth. Caudal fin, with the upper lobe falcate, much longer than the lower. Dorsal fin short, high, falcate, the anterior rays $I \frac{1}{3}$ to $I \frac{1}{2}$ times base of fin, the free border much concave. Depth $3 \frac{1}{2}$ in length. Head 5 to $5 \frac{1}{4}$. D. I2 or I3. Scales 6-45-5. Lower fins bright red.

"Abundant in Lake Erie; our specimens from Sandusky, Toledo and Cincinnati," Jordan and Evermann (Bull. 47, U. S. Natl. Mus.).

\section{Genus: Placopharynx.}

\section{Placopharynx duquesnii (Le Sueur).}

Head 4 ; snout rounded, projecting; lower jaw somewhat oblique when closed; eye $4 \frac{1}{2}$ in head. Body rather stout, somewhat compressed, in form like that of $M$. aureolum; D. 13; A. 7 (not 9 , as is usually given, in any Ohio specimens I have seen); scales 6-45-6. Lower pharyngeal bones very strong, the lower teeth on these bones very strong and molar-like, little compressed, and having broad grinding surfaces.

This species so closely resembles $M$. aureolum that it can be positively distinguished only by the appearance of the lower pharyngeal teeth, and it has no doubt been much overlooked. Recorded by Jordan (Ohio Rept.) on the strength of a skeleton found by Dr. J. M. Wheaton in the Scioto river at Columbus, one of the very few specimens known at that time. The species has since proved to be well distributed over the state, though not usually abundant. Hamilton County, not rare in the Ohio, Henshall, I888; Lorain County, Lake Erie, common with other 
mullets, McCormick, I 892 ; Franklin County, Scioto river, Olentangy river and Big Darby creek, Williamson and Osburn, I897; Ohio river at Ironton, Wabash river at Celina, R. C. Osburn, I899; Ohio river at Bellaire, R. C. Osburn, I9oo.

\section{Genus: LAgOCHILA.}

Lagochila lacera Jordan and Brayton. HARE-LIP SUCKER;

CUT-LIPS.

Head short, conical, with lengthened snout, the region between the eyes flattened and with prominent mucous ridges. Cheeks and lower part of head rather swollen. Opercle much reduced, its greatest length scarcely greater than diameter of eye. Head $4 \frac{2}{3}$ in length. Eye $4 \frac{1}{2}$ in head, 2 in length of snout. Body rather slender, depth $4 \frac{2}{3}$. Dorsal fin rather low, its rays 12 ; A. 7 ; V. 9 ; scales $5-45^{-5}$. Mouth very singular ; the upper lip is broad and fleshy, not separated from the skin of the forehead by a crease ; at each side of the mouth a sharp fold of skin is formed, which descends to the mid line below, passing under the lower jaw, but is separated from that of the opposite side by a longitudinal crease; in front of these the fleshy lower lip is split into two large depending lobes.

This species has been recorded for but three localities in the state. Its rare occurrence in the state was first noted by Dr. Jordan in Klippart's 'Second. Annual Report of the Ohio State Fish Commission for I877," where he says: "Mr. Klippart finds it very abundant in the Scioto, where it has been overlooked by all the collectors from Rafinesque and Kirtland down,' and Mr. Klippart further comments: "The fisherman assured me that he had taken them several years in succession." 'Twenty years later, the investigations on the fishes of Franklin County, carried on by Mr. Milliamson and the writer, and extending over a period of several years, failed to bring to light a single specimen of this species, though the Scioto river was hauled in many places. The species has been taken in the state by Kirsch, in I893, in the Auglaize river at Cloverdale, and in the Blanchard river at Ottawa. 


\section{Family: Cyprinides (The Minnows). \\ Key to Genera.}

I. (Dorsal fin long, with 2 or 3 spines, and 18 or 20 rays ; introduced species.
A. Teeth in 3 rows, I, I, 3-3. I, I, all molar ; 4 barbels.-
CYPRINUS.

AA. Teeth in I row, $4-4$, molar, but compressed ; barbels wanting.-

CARAsSiUs.)

II. Dorsal fin short, without developed spine.

A. Air bladder surrounded by many convolutions of the very long alimentary canal.-

CAMPOSTOMA.

AA. Air bladder above the alimentary canal, not surrounded by convolutions of the intestine.

B. Alimentary canal more than twice the length of body; teeth in I row; peritoneum usually black.

C. Teeth 5-5 or 4-5; scales minute.-

CC. Teeth $4-4$; scales larger.

D. A small barbel present at base of maxillary ; color silvery,-

$$
\text { - HYBOGNathus. }
$$

DD. Barbel wanting; color olivaceous, little silvery.-PIMEPHALES.

BB. Alimentary canal less than twice the length of body; peritoneum usually silvery.

E. Lower jaw normally formed, dentary bones free from each other except at the symphysis.

F. Teeth in main row 5-5 or 4-5.

G. Abdomen rounded behind ventral fins, not compressed into a scaleless ridge; anal basis :hort.

H. A minute barbel present on maxillary at a little distance above its base.- SEMotilus.

HH. Maxillary without barbel.

I. Teeth in 2 rows, $2,4-5,2$ - - L,euciscus.

II. Teeth in I row, 5-5. Mouth extremely small.

OPSOPEODUS.

GG. Abdomen compressed behind ventral fins into a sharp,

FF. Teeth in main row 4-4 scaleless ridge; anal basis longer.-- ABRAMis.

J. Maxillary without barbel.

K. No cavernous lymph spaces visible in mandible, sub-opercle and inter-opercle.

L. First (rudimentary) ray of dorsal detached from the first developed ray and connected to it by a membrane; a conspicuous black spot at base of caudal and dorsal-Cliola.

LL. First (rudimentary) ray closely attached to first developed ray.- Notropis.

KK. Mandible, sub-opercle and inter-opercle, with conspicuous, externally visible, cavernous lymph chambers.-

JJ. Maxillary barbel present.

ERICYMBA.

M. Premaxillaries not protractile, connected to skin of forehead in the median line without a cross groove; teeth 2, 4-4, 2 RHINichthys.

MM. Premaxillaries protractile, a cross groove separating them from the skin of forehead in front; only I tooth in lesser row.-

HYBOPSIS.

EE. Lower jaw singularly formed, the dentary bones parallel and united for their entire length; a conspicuous, fleshy lobe on each side at base.Exoglossúm. 


\section{Genus: Cyprinus.}

\section{Cyprinus carpio Linnaeus. THE CARP.}

The Carp may be readily distinguished from any of our native Cyprinida by the presence of four long barbels, and by the very long dorsal fin-about 20 rays-preceded by a stout spine, which is serrated behind. Anal fin short, of about 5 rays, also preceded by a spine. The lower pharyngeal teeth, unlike those of any native American Minnow, are in 3 rows, I, I, 3-3, I, I. The lateral line is complete. Many varieties have resulted from cultivation. Chief among these are the "Full-scale," in which the body is covered with strong scales, after the formula, 6-40-5; the "Half-scale" or "Mirror," characterized by a few rows of very large scales; and the "Leather Carp," in which the scales are entirely absent.

The Carp was first introduced into the state to stock ponds and lakes, but, escaping from cultivation, has become generally distributed over the state and occurs in streams as well as ponds and lakes. Recorded for the state by Henshall, I889, in Ross lake and Little Miami river; Lorain County, occasionally taken in the rivers, McCormick, I892; Maumee river at Toledo (abundant), St. Marys river at Rockford, Tiffin river at West Unity, and west end of Lake Erie (abundant), Kirsch, I893; Franklin County, "of" general distribution throughout the county," Williamson and Osburn, I897; Knox County, Big Jelloway creek, "very common," Parker, Williamson and Osburn, ISgS; very common in Sandusky Bay, R. C. Osburn, I899; Wheeling creek at Bridgeport, Ohio river at Bellaire, and Licking reservoir, R. C. (Osburn, Iguo.

\section{Genus: Carassius.}

\section{Carassius auratus (Linnaeus). GoLDFISH.}

The Goldfish may be distinguished from our native Minnows by the very long dorsal fin, preceded by a stout, serrated spine; the anal of 7 rays, with a similar spine. From the Carp it is distinguished by the absence of the barbels about the mouth, and by the teeth, which are 4-4. As in the Carp, cultivation has produced many varieties.

It has escaped from cultivation in some parts of Ohio, and has been reported by Hensha11, I888, as "not rare in the canal basin near Elmwood, Hamilton County.

\section{Genus: TINCA.}

\section{Tinca tinca (Linnaeus). TENCH.}

In the spring of $I 898$ a freshet carried away the banks of an artificial lake on the grounds of the Ohio State University, at Columbus, and many of the Tench, with which the lake was stocked, escaped into the Olentangy river. In September of the same year specimens were taken at the mouth of the small stream flowing from the lake to the river. Whether the Tench will hold its own in the streams of Ohio yet remains to be seen. 


\section{Genus: Campostoma.}

\section{Campostoma anomalum (Rafinesque). STONE-ROLLER; 。 STEel-BaCKed Chub; MamMY ; Dough-Beldy.}

This species is most easily distinguished by an examination of the intestine, which is very long and is wound in many convolutions about the airbladder. This arrangement is peculiar to this genus among all known fishes. Head 4 ; depth $4 \frac{2}{5}$; eye 5 to $5 \frac{1}{2}$ in head; D. 8; A. 7 ; scales $7-48-6$; teeth $4-4$. Body stoutish. Snout somewhat decurved, mouth inferior. Color brownish, almost black in adult breeding males; sides brassy, irregularly mottled with dark olivaceous or brown; fins usually plain, in breeding males the dorsal is tinged with orange, a black bar through its middle, other fins more or less tinged with orange. Entire dorsum of breeding males covered with tubercles. Young with a dark lateral band extending onto gill covers and between. eye and tip of snout. Length 6 to 8 inches.

A very abundant and widely distributed species, generally most abundant in small streams and on ripples of larger ones. First recorded for the state by Kirtland under the name Exoglossum lesueurianum; given by Jordan as "extremely abundant in every stream in the state" ; Hamilton County, "abundant in every stream explored," Henshall, I 888 ; Lorain County, "common in most of our streams," McCormick, I892 ; Franklin County, "very abundant everywhere," Williamson and Osburn, I897 ; Big Jelloway creek system, " apparently the most abundant species," Parker, Williamson and Osburn, I898 ; recorded for many places in the Maumee river system (not taken in St. Mary's river) by Kirsch, I893; Ohio river and Ice creek at Ironton, Huron river at Milan, Ashtabula creek at Ashtabula, Wabash river at Celina, Stillwater and Wolf creeks near Dayton, north fork of Licking river at Newark, R. C. Osburn, I899; Niggermill Run at Salem, E. B. Williamson, I900; Cuyahoga river at Kent and Hawkins, Breakneck creek at Kent, Chippewa lake, Summit lake, Grand river at Painesyille, Chagrin river at Willoughby, Wheeling creek at Bridgeport, Ohio river and McMahon creek at Bellaire, Licking reservoir, R. C. Osburn,. I900. 


\section{Genus: Chrosomus.}

Chrosomus erythrogaster Rafinesque. RED-BELLIED DACE.

Head 4; depth 4; eye $3 \frac{1}{2} . \quad$ D. 8 ; A. 8; teeth 5-5; scales I6-85-IO. Body rather elongate, the head pointed; mouth small, terminal, somewhat oblique. Lateral line developed backward about as far as the dorsal fin. Color above, brownish; a black vertebral line, bordered on either side by a row of black dots; sides creamy white, bordered above and below with a black band, the lower the wider and extending forward through eye; under parts white, in breeding males entirely suffused with vermillion; fins all bright sulphur yellow, the dorsal with a bright red spot at its base, anteriorly; females and young less brilliantly colored. Length 2 to 3 inches.

The Red-bellied Dace is widely distributed and is generally abundant where found, but it is strictly a " brook species," being confined to small clear streams and spring runs. Recorded for the state by Dr. Kirtland ; Lorain County, "I have found them in but one stream, Spring brook,'” McCormick, I892 ; "collected by Prof. Meek in Lost creek, near Defiance," Kirsch, I893; Franklin County, Grant's Run and Plum Run, tributaries of the Scioto river, in abundance, Williamson and Osburn, I897; Knox County, Parker's Run, a tributary of Big Jelloway creek, " in considerable numbers,' ' Parker, Williamson and Osburn, x898 ; Licking County, occurring in abundance in spring runs tributary to North Fork of Licking river near Newark, R. C. Osburn, I899; Niggermill Run at Salem, E. B. Williamson, I90o.

\section{Genus: Hybognathus.}

Hybognathus nuchalis Agassiz. SILVERy Minnow.

Head $4 \frac{1}{2}$ to 5 ; depth $4 \frac{1}{8}$; 'eye 4 ; D. 8 ; A. 7 ; teeth $4-4$; scales $5-38-4$. Body elongate, comparatively slender. Head moderate, the profile evenly curved; upper jaw heavy, lower thin. Scales large and silvery, 12 to $\mathrm{I} 4$ in front of dorsal. Lateral line decurved. Intestines very long, 7 to ro times the length of body. Color olivaceous green above, translucent in life; sides clear silvery; fins plain. Length 4 to 7 inches.

This species seems to be confined to the southwestern part of the state. Jordan, in his Ohio Report, gives it as abundant in small streams flowing into the Ohio river, but Dr. Henshall records it for only White Oak creek and the Ohio river, and in my work at Ironton and Bellaire I failed to find it. This species is not mentioned by any other collector. 


\section{Genus: Pimephales.}

\section{Key to Species.}

A. Lateral line more or less incomplete; body very short and stout.-

AA. Lateral line complete; body moderately elongate.-

promelas. notatus.

\section{Pimephales promelas Rafinesque. FAT-HEAD.}

Head 4 ; depth $3 \frac{3 / 4}{4}$ to 4 ; eye 4 . D. I, 7 ; A. 7 ; scales 7 or $8-43$ to $47-5$ or 6. Body very short and deep. Head short, everywhere convex, almost globular in adult males. Scales deep, closely imbricated; lateral line incomplete. Color dark olivaceous above, paler below; a dark lateral band and caudal spot; dorsal fin with a dusky shade through it at the middle, Breeding males with the head nearly black, with tubercles on snout and lower jaw. Length $2 \frac{1}{2}$ inches.

Recorded by Kirtland. Given by Jordan as most abundant in small streams flowing into the Ohio; Hamilton County, "very abundant everywhere," Henshall, I888 ; Lorain County, "not common, but found in most of the streams," McCormick, I892 ; Maumee river at Cecil, Lost and Gordon creeks near Cecil, Sugar creek at Lima, Kirsch, I893; Knox County, Big Jelloway creek, rare, Parker, Williamson and Osburn, I 898 ; Ohio river at Ironton, Wabash river at Celina, Stillwater and Wolf creeks near Dayton, R. C. Osburn, I899; Niggermill Run at Salem, E. B. Williamson, I900; Pippin lake, Cuyahoga river at Hawkins, Ohio river at Bellaire, R. C. Osburn, I9oo.

\section{Pimephales notatus (Rafinesque). BLUNT-NOSED Minnow.}

Head $4 \frac{1}{2}$; depth $4 \frac{1}{2}$ to 5 ; eye 4 . D. I, 7 or 8 ; A. 7 ; scales $6-45^{-4}, 22$ in front of dorsal, much crowded and irregularly arranged anteriorly. Body rather elongate. Head moderate, the snout very blunt and convex; top of head depressed; mouth small, inferior, horizontal. Color olivaceous, sometimes very dark; a black spot at base of dorsal fin in front. Males in breeding season with the head black or nearly so, and with about 16 large tubercles on the snout. Length 4 inches.

This species is much more abundant than the preceding. "Swarms in all the streams of the state," Jorelan; Hamilton County, "the most abundant minnow," Henshall. I888 ; Lorain County, "very abundant in small streams," McCormick, I892 ; Kirsch records it for every stream of the Maumee river system explored in Ohio; Franklin County, " our most abundant minnow, 
in great numbers in every stream,' Williamson and Osburn, I 897 ; Knox County, abundant in every stream of the Big Jellowway creek system, Parker, Williamson and Osburn, I898; Ohio river and Ice creek at Ironton, Huron river at Milan, Sandusky Bay, Ashtabula creek at Ashtabula," Wabash river at Celina, Stillwater and Wolf creeks near Dayton, North Fork of Licking river near Newark, R. C. Osburn, I899; Niggermill Run at Salem, Mahoning river, E. B. Williamson, I9oo; Pippin lake, Chippewa lake, Summit lake, Cuyahoga river at Kent and Hawkins, Breakneck creek at Kent, Grand river at Painesville, Chagrin river at Willoughby, Wheeling creek at Bridgeport, Ohio river and McMahon's creek at Bellaire, Licking reserroir, R. C. Osburn, I900.

\section{Genus: Semotilus.}

\section{Semotilus atromaculatus (Mitchil1). Horned DACE; ChUB.}

Head $3 \frac{3}{4}$; depth 4 ; eye 5 to $5 \frac{1}{2}$. D. 7 ; A. 8; scales 9-55 to $60-6$, about 30 in front of dorsal; teeth 2, 5-4, 2. Head large and heavy, broad and rounded above; snout broad; mouth broad, oblique; a small barbel on the maxillary some distance above its posterior end, not evident in young specimens. Body stont, arched in front of dorsal. Dorsal inserted behind ventrals. Color dusky olivaceous or bluish above, paler below; sides with a brassy luster; an indistinct lateral band and caudal spot (these markings (listinct in young). Dorsal with a black spot at its base anteriorly. Sides of head and lower fins rosy in breeding males. These have also the snout covered with tubercles. Length Io inches.

A widely distributed species, occurring abundantly in brooks throughout the state, less commonly in the larger streams, and rarely in lakes. In seining up stream the increase in number of individuals of this species as the headwaters are approached is very noticeable. Kirtland, following Rafinesque, recorded it for the state as two species, $S$. dorsalis and $S$. cephalus. Both are synonyms of S. atromaculatus. Hamilton County, "abundant in all streams," Henshall, I 888 ; Lorain County, " abundant in most of the streams," McCormick, I892 ; " generally distributed throughout the Maumee river basin," Kirsch, I893; Franklin County, abundant in all streams, Williamson and Osburn, I897; Knox County, Big Jelloway creek system, Parker, Williamson 
and Osburn, I898; Ice creek at Ironton, John's creek at Water1oo, Huron rirer at Milan, Ashtabula creek at Ashtabula, Wabash river at Celina, Stillwater and Wolf creeks near Dayton, North Fork of Licking river at Newark, R. C. Osburn, I899; Niggermill Run at Salem, Mahoning river, E. B. Williamson, I900; Sandusky Bay, Cuyahoga river at Kent and Hawkins, Breakneck creek at Kent, Chippewa lake, Grand river at Painesville, Chagrin river at Willoughby, R. C. Osburn, I90o.

\section{Genus: LeUCiscus.}

\section{Leuciscus elongatus (Kirtland). RED-SIDED DACE.}

Head 4 ; depth 5 ; eye 4 to $4 \frac{1}{3}$. D. 8 ; A. 9; scales 10-70-5; teeth 2, 5-4, 2. Body elongate, compressed; head long, pointed; mouth very large, oblique, the maxillary extending to middle of orbit; lower jaw projecting, with a small knob at its symphysis. Color above varying from a dark bluish to greenish, sides somewhat paler and mottled; a dark vertebral line; along the side is a broad band, bright blood red anteriorly, black posteriorly, the two colors shading into each other imperceptibly at about middle of body; above this band is a narrow brassy band; belly silvery white. In breeding males the belly and lower fins are tinged with rosy; in females and young the bright colors are subdued or wanting. Length 5 inches.

The Red-sided Shiner is certainly one of the most elegant of fishes. It is, generally speaking, a brook species, inhabiting clear deep pools of brooks and spring runs, though Dr. Kirtland, who described the species, records it for Lake Erie. It is found in the tributaries of the Ohio and of the Lake, but has not been noticed in the western part of the state. Mahoning river in Trumbull County, and Lake Erie near Cleveland, Kirtland; Lorain County, "common in Spring brook, but not found elsewhere," McCormick, I892 ; Knox County, Little Jelloway creek, Black Run, Parker's Run, Joe Sapp Run, Shadly Run and Doudy creek, tributaries of Big Jelloway creek, common, Parker, Williamson and Osburn, I898; Wilson's Run, a small tributary of the North Fork of Licking river near Newark, R. C. Osburn, I899; Niggermill Run at Salem, E. B. Williamson, I900; a small tributary of the Grand river at Painesville, R. C. Osburn, I900. 


\section{Genus: Opsopeedods.}

Key to Species.

A. Lateral line complete or very nearly so: dorsal fin with black blotch on anterior rays, usually none on the posterior.-

emilice.

AA. Lateral line always incomplete; dorsal usually with a conspicuous black spot on posterior rays -

megalops.

\section{Opsopœodus emiliæ Hay.}

Head about $4 \frac{1}{2}$; depth $4 \frac{2}{5}$; eye 3 . D. 9 ; A. 8 ; scales $5-40-3$; teeth $5-5$, very slender, strongly hooked, and deeply serrate. Body rather elongate, moderately compressed, not elevated. Head short and slender. Muzzle blunt and rounded. Mouth very small and very oblique, smaller than in any other of our Cyprinido, with scarcely any lateral cleft. Caudal peduncle long and slender, caudal deeply forked, Breast naked; 16 scales before dorsal. Lateral line complete or very nearly so. Yellowish; sides silvery; scales above dark edged; usually a dark lateral band from snout to caudal, above and below which are series of black dots; anterior rays of dorsal dark, no black spot on the posterior rays.

Given by Jordan and Evermann (Bull. 47) for Lake Erie ; "two small specimens from the St. Mary's river at St. Mary's," Kirsch, I893.

\section{Opsopœodus megalops (Forbes).}

Head $4 \frac{3}{4}$; depth 4 to 5 ; eye $23 \frac{4}{4}$. D. 7 or 8 ; A. 7 or 8 ; scales $5-39-4$, I 5 before dorsal. Teeth $5-5$, hooked and crenate. Lateral line always incomplete, sometimes on 4 or 5 scales only; sometimes extending with interruptions to middle of caudal peduncle. Body slender, fusiform; mouth small, terminal, oblique, so much so in old specimens as to appear almost vertical, the chin projecting beyond mouth, in younger specimens the mouth is less oblique. Top of head covered with prickles in old males. Fins large, caudal deeply forked. Breast partly naked. Yellowish brown, sides silvery; scales above dark-edged. Dorsal fin with a black blotch on 4 anterior rays; a second black blotch usually present on 3 posterior rays. Length $2 \frac{1}{3}$ inches.

I have given above the separation of $O$. emilice and $O$. megalops as given by Jordan and Evermann (Bull. 47, U. S. Nat1. Mus.) They suggest in regard to $O$. megalops that it is "perhaps not a distinct species." A comparative study of these forms confirms this belief. A dozen specimens taken by the writer in the headwaters of the Wabash river at Celina, August, I899, and two from Summit lake at Akron, July 30, I900, are referable to $O$. megalops as given above, but so many variations between 
O. cmilic and megalops exist among these specimens that it is possible to establish a graduated series between the two species, and none of the characters given in the abore separation are found to be constant. The lateral line in some cases ceases in front of the dorsal fin, and in others is continuous to within two or three scales of the caudal. The second dorsal spot is also subject to great variation, for, while in old males it is distinct, in some cases it is very indistinct or wanting altogether. The fin formulæ and squamation of the breast also vary. Recently, through the kindness of Dr. S. E. Meek, I have been permitted to examine specimens of $O$. emilice from Indian Territory, Arkansas and Illinois, in the Field Columbian Museum at Chicago. These specimens show much the same variation as that given for $O$. megalops. As I have had no opportunity to compare with the type specimens, I hesitate to reduce $O$. megalops to synonymy, although the two species, as determined by Dr. Meek and myself, undoubtedly intergrade.

\section{Genus: Abramis.}

\section{Abramis crysoleucas (Mitchill). GOLDEN SHINER;}

GOLDEN BREAM; ROACH.

Head $4 \frac{1}{2}$; depth 3. D. 8; A. I3; scales 10-46 to $55-3$; teeth $5-5$. Body strongly compressed, the belly behind ventrals compressed into a sharp keel, over which the scales do not pass. Color, greenish above, the sides silvery, with bright golden reflections. Length about a foot.

The Golden Bream is an abundant resident of the state in suitable localities, being found chiefly in ponds, quiet pools and weedy bayous, apparently more common in the northern part of the state. Given by Rafinesque under the name Notemigonus auratus for the Ohio and Miami rivers; recorded by Kirtland under the name Rutulus crysoleucas; given by Jordan as "extremely abundant in every pond, lake or bayou"; Hamilton County, "common in Bloody Run and Clear creek," Henshall, I888; Lorain County, "very common in still waters," McCormick, 1892; Maumee river at Cecil, Grand Rapids, Waterville and Toledo, St. Mary's river at St. Mary's and Rockford, Tiffin river at West Unity, Auglaize river at Oakwood and Defiance, Sugar creek and Lost creek at Lima, Blanchard river at Findlay, 
Kirsch, I893; Franklin County, Scioto river, Scioto Big Run, Big Walnut creek, Mason's Run, Big Darby creek, Hell Branch, Williamson and Osburn, I897; Knox County, Big Jelloway creek, Parker, Williamson and Osburn, I898; Sandusky Bay, Ashtabula creek at Ashtabnla, Wabash river at Celina, R. C. Osburn, I899; Niggermill Run at Salem, E. B. Williamson, 1900 ; Chippewa lake, Licking reservoir, R. C. Osburn, I900.

\section{Genus: Cliola.}

Cliola vigilax (Baird and Girard).

Head $4 \frac{1}{4}$; depth $4 \frac{1}{2}$; eye $3 \frac{1}{2}$. D. 8 ; A. 7 ; scales $8-42-6$, about 28 before dorsal; teeth 4-4, with grinding surface and slight hook. Superficially, much resembling Pimephales notatus, but the form is more stout, the mouth more terminal, and the alimentary canal less than twice the length of the body. Caudal peduncle quite deep. Color, greenish, sides pale, darker above, the scales above dark-edged; a dark lateral band ending in a distinct caudal spot; a well defined black spot on anterior rays of dorsal. Length 3 inches.

This minnow has, to the best of my knowledge, been recorded from but two localities in the state. It has been taken by Henshall in Hamilton County, " common in O'Bannon creek," and a single specimen was taken in Big Walnut creek, Franklin County, by Mr. E. B. Williamson and the writer in I897. It is probably common nowhere in the state except in the southwestern part, as its range is for the most part farther south and west. 


\section{Genus: Notropis.}

\section{Key to Species.}

A. Teeth 4-4, I, 4-4, 0, or I, 4-4, I (sometimes 2 teeth in one or both inner rows in $N$. hudsonius and $N$. heterodon).

B. Scales not very closely imbricated, not notably deeper than long; dorsal inserted nearly over the ventrals; no black spot on dorsal fin.

C. Teeth one-rowed, 4-4 (sometimes $2,4-4,2$ in $N$. heterodon).

D. Lateral line usually more or less incomplete; small species, usually with a dusky lateral band.

E. Mouth very small, chin pale.-

EE. Mouth moderate; chin black.-

cayuga.

DD. Lateral line always complete; small, weak species.

F. Fins all small and low, pectorals not reaching ventrals.-

FF. Fins high, pectorals reaching ventrals -

volucellus.

CC. Teeth two-rowed, $1,4-4,0 ; 1,4-4$, I; or $1,4-4,2$, the grinding surface more or less developed.

G. No distinct dark spot at base of caudal.-

GG. A distinct dark spot present at base of caudal fin.- hudsonius.

BB. Scales deeper than long, closely imbricated along side of body. Usually a distinct black spot on last rays of dorsal.- whipplii.

AA. Teeth 2, 4-4, 2 (2, 4-4, I in $N$. jejunus).

H. Anal fin short, of 7 to 9 developed rays.

I. Teeth with the grinding surface developed.

J. Scales closely imbricated along the sides, no dark spot at base of caudal.-

cornutus.

JJ. Scales not closely imbricated, a dark spot at base of caudal at least in young.

K. I3 scales before dorsal fin.- heterodon.

KK. I8 scales before dorsal.-

hudsonius.

II. Teeth without evident grinding surface, scales not closely imbricated.

L. Eye very large, $2_{5}^{3}$ in head; teeth 2, 4-4, 2.- ariommus.

LI. Fye $3 \frac{2}{3}$ in head. teeth $2,4-4,1$ - jejunus.

HH. Anal fin long, of II or I2 rays; dorsal inserted behind ventrals.

M. Scales not closely imbricated on sides, not crowded anteriorly.

N. Eye very large, $23 / 4$ to 3 -

NN. Eye smaller, $3 \frac{1}{4}$ to 4 .

o. Front of dorsal midway between snout and base of caudal fin; eye $3 \frac{\pi}{4}-$ atherinoides.

OO. Front of dorsal nearer to base of caudal than to snout; eye 4.-rubrifrons.

MM. Scales small and crowded anteriorly, closely imbricated; a black spot at base of caudal.umbratilis.

\section{Notropis cayuga Meek.}

Head 4 or a little over; depth $4 \frac{1}{2}$; eye $3 \frac{1}{2}$. D. 8; A. 8; scales in lateral line about 36 , I 4 before dorsal; teeth $4-4$. Close to $N$. heterodon, from which it can be distinguished most readily by the absence of any black on the chin. Lateral line wanting on some scales. Jaws nearly equal. A black band along lateral line, continued forward along sides of head and around snout on upper jaw. Length $2 \frac{1}{2}$ inches. 
First recorded for the state by Kirsch, I 893 , " a few specimens from the Maumee river at Toledo"; Franklin County, "rare in Big Walnut and Little Darby creeks, common in Mason's Run,'” Williamson and Osburn, I897; Sandusky Bay and Ashtabula creek at Ashtabula, common in both places, R. C. Osburn, I899. This species seems to have been overlooked or confused with some other species by the earlier investigators, as its occurrence in both the Lake and Ohio river drainage at the points above noted would indicate a pretty general distribution over the state in suitable localities.

\section{Notropis heterodon (Cope).}

Head 4; depth 4; eye 3 , longer than snout. D. 8; A. 8; scales 5-36-3, I 3 in front of dorsal. The lateral line incomplete, extending usually about to dorsal fin, but varying greatly; teeth $4-4$ (sometimes $2,4-4,2$ ). Body moderate; the back slightly elevated. dorsal inserted nearer the snout than base of caudal. Coloration olivaceous, darker on the back; a distinct lateral band, which passes forward through eye and on both jaws; chin distinctly black. Said to be an exceedingly variable species.

Taken by the writer in Sandusky Bay, July, I899, and again in Sandusky Bay at Cedar Point and Black Channel, I9oo.

Notropis blennius (Girard). STRAW-COLORED Minnow.

D. 8; A. 8; scales 5-36-4, I4 in front of dorsal; teeth 4-4. Head 4; depth 4 to 5 ; eye large, 3 in head. Body moderately stout, but little compressed. Head rather broad; mouth small, inferior, horizontal. Lateral line complete. Dorsal fin low, its longest ray $3 / 4$ of head. Coloration, pale or yellowish olive; sometimes with a dark lateral band, and edges of mouth dark. Length $2 \frac{1}{2}$ inches. An exceedingly variable Minnow.

This insignificant looking species occurs widely and abundantly throughout the state and has been recorded by all the recent writers upon the fishes of the state, beginning with Jordan (Ohio Rept.), under various names $-N$. blennius, $N$. deliciosus and $N$. stramineus. Hamilton County, " abundant in Little Miami river and Clough creek," Henshall, I888; Lorain County, given as two species, $N$. deliciosus, very abundant in all the streams, and $N$. stramineus, not common, McCormick, I892; Maumee river at

* Notropis anogenus Forbes and $N$. fretensis (Cope), two small species closely resembling $N$. heterodon and $N$. cayuga, respectively, have been taken almost on our borders in streams flowing into the state. They may be looked for in north-western ohio. $N$. anogenus may be known from $N$. heterodon by the usually complete lateral line and the included lower jaw. $N$. fretensis is separated from $N$. cayuga with which it is perhaps identical), by the complete lateral line and the presence of 17 scales in front of the dorsal. 
Antwerp, Cecil, Defiance and Waterville, Tiffin river at Brunersburg. Auglaize river at Cloverdale, Sugar creek at Lima, Blanchard river at Ottawa, Bearer creek at Grand Rapids, Kirsch, I893; Franklin County, common in almost every stream, females with eggs, July r6, Irilliamson and Osburn, I897 ; Knox County, Big Jelloway creek system, "abundant, females with ripe eggs on May 25," Parker, Williamson and Osburn, I898; Ice creek at Ironton, John's creek at Waterloo, Huron river at Milan, Sandusky Bay, Ashtabula creek at Ashtabula, Wabash river at Celina, Stillwater and Wolf creeks near Dayton, North Fork of Licking river at Newark, abundant in most places, R. C. Osburn, I899: Pippin lake, Cuyahoga river at Hawkins, Grand river at Painesville, Chagrin river at Willoughby, Wheeling creek at Bridgeport, Ohio river and McMahor's Run at Bellaire, Licking reservoir, R. C. Osburn, I9oo.

\section{Notropis volucellus (Cope).}

Head $3 \frac{3}{4}$; depth 4 ; eye $3 \frac{1}{3}$. D. 8 ; A. 8 ; scales $4-34-3$; teeth $4-4$. Fins more elongate than in related species, the pectorals reaching ventrals. Very similar to $N$. blennius, but distinguished especially by the noticeably higher fins. Length $2 \frac{1}{2}$ inches.

The only record I am able to find of the occurrence of this species in Ohio is that given by Kirsch in his "Report upon Investigations in the Maumee River System," in which he mentions the fact that specimens from Gordon creek, taken by Prof. S. E. Meek, are given him as Notropsis deliciosus var. volucella Cope. Cope's volucellus is now regarded as a distinct species.

Notropis shumardi (Girard).

Head $3 \frac{3}{4}$; depth $4 \frac{1}{5}$; eye very large, $2 \frac{1}{3}$ to 3 in head. D. 8 ; A. 7 or 8 ; scales 4 or 5-36-2 to $4, I 3$ in front of dorsal; teeth I, 4-4, I, with deep grinding surface, and the edge strongly crenate. Body compressed, the back elevated; tail slender. Head compressed, flattened above, below and on the sides; snout short, obtuse; mouth very oblique, terminal, lower jaw included. Fins large. Lateral line complete, decurved. Color, olivaceous above, pale below; a dark lateral band, and vertebral line; scales above dark-edged. Length 3 inches.

Recorded by Kirsch as $N$. boops Gilbert, "common in the Maumee river at Grand Rapids," and "five specimens from the 
Blanchard river at Findlay,' I893. Rare in Big Walnut creek, Franklin County, Williamson and Osburn, I897; a single specimen from Stillwater creek near Dayton, R. C. Osburn, I899.

\section{Notropis hudsonius (De Witt Clinton). SPOT-TAILED MINNow; SHINER.}

Head 43/4; depth 4 ; eye 3 . D. 8; A. 8; scales 5-39-4, IS before dorsal; teeth I, 4-4, O or I or 2 . Body elongate, considerably compressed in adult. Head short; muzzle blunt, decurved, shorter than the very large eye; mouth moderate, nearly horizontal, jaws sub-equal. Lateral line nearly straight, slightly decurved anteriorly. Coloration very pale, with a broad silvery band along side, this frequently underlaid with a dusky band. A dark spot at base of caudal, most distinct in young. Length 4 to 6 inches.

This species is apparently confined to the most northern portions of the state, in Lake Erie and its larger tributaries. Lorain County, "common in the lake and at the mouth of the rivers," McCormick, I 892 ; "very common in the Maumee river at Grand Rapids, a single specimen at Toledo,' Kirsch, I893; Lake Erie near Sandusky, abundant, R. C. Osburn, I90o; Sandusky Bay, Morse and Herbert T. Osborn, I900.

\section{Notropis whipplii (Girard). SILVER-FIN.}

Head $4 \frac{1}{1}$; depth 4 in adult males, females and young much slenderer; eye $4 \frac{1}{2}$. D. 8 ; A. 8 or 9 ; scales 5 or $6-38$ to $40-3$ or 4 ; teeth I, $4-4$, I. Body moderately elongate, compressed, the back and belly about equally arched. Head rather short and deep. Scales closely imbricated (much higher than wide) and of a very regular pattern, about 18 in front of dorsal. Color leaden or steel-blue, the sides silvery; a dark vertebral line; a black spot covering the posterior 3 membranes of the dorsal fin, this sometimes very much reduced in young and females, but always present. Breeding males have the fins tipped with creamy white, and the top of head and dorsal region in front covered with small prickles. Length 4 inches.

This elegant little fish is widely distributed throughout the state, and is usually quite common in all suitable localities. Recorded by Kirtland under the name Luxilus kentukiensis. Given by Jordan in his Ohio Report under the name Hudsonius analostanus, which he here confuses with $N$. whipplii. Notropis (Hudsonius) analostanus is an eastern form, possibly not specifically distinct from $N$. whipplii (see Jordan and Evermann, Bull. 47, U. S. Natl. Mus.) Hamilton County, common in all streams explored, Henshall, I 888 ; Lorain County, all streams examined, 
but not very common, McCormick, I892; taken throughout the Maumee river basin in Ohio, except in Gordon creek and the west end of Lake Erie, Kirsch, I893; Franklin County, occurs abundantly in all the larger streams, females with ripe eggs June 28 , Williamson and Osburn, I897; Knox County, Big Jelloway creek and tributaries, not rare, Parker, Williamson and Osburn, I898; Ohio river at Ironton, Huron river at Milan, Sandusky Bay, Ashtabula creek at Ashtabula, Wabash river at Celina, Stillwater and Wolf creeks near Dayton, North Fork of Licking river at Newark, R. C. Osburn, I899; Mahoning river, E. B. Williamson, I900; Cuyahoga river at Hawkins, Chippewa lake, Grand river at Painesville, Chagrin river at Willoughby, Wheeling creek at Bridgeport, Ohio river and McMahon's Run at Bellaire, Licking reservoir, R. C. Osburn, I9oo.

\section{Notropis cornutus (Mitchill). COMMON SHINER; SILVERSIDES.}

Head $3 \frac{1}{4}$ to $4 \frac{1}{4}$; depth about $3\left(23 / 4\right.$ to $\left.3 \frac{1}{2}\right)$; eye $4-5 \frac{3}{4}$. D. 8 ; A. 9; scales 6-4I-3 or 4, closely imbricated, I8 or 20 before dorsal; teeth $2,4-4,2$, with narrow grinding surface. Body varying much with age, in young slender, in adult short, deep and compressed. Lateral line decurved. Color above, dark olive green to steel-blue, sides silvery, with a brassy lateral band; a brassy vertebral line (this color showing only in fresh specimens, sometimes appearing as a dark line when out of water). Fins all plain, rosy tipped in breeding males. Females and young plainer. One of the most variable of our Minnows, varying with age, sex and season. Length about ro inches.

One of the most abundant of fishes all over the state. Given by Kirtland as Rutulus compressus and Luxulus chrysocephalus; by Jordan as Luxulus cornutus. Hamilton County, as Notropis megalops, " abundant everywhere," Henshall, r888; Lorain County, "very common everywhere," McCormick, I892; Maumee river system, "every stream," Kirsch, I893; Franklin County, "taken in every stream, generally abundant, females with eggs on July 6," Williamson and Osburn, I897; Knox County, taken in every stream of the Big Jelloway creek system, Parker, Williamson and Osburn, I898; Ohio river and Ice creek at Ironton, John's creek at Waterloo, Huron river at Milan, Sandusky Bay, Ashtabula creek, Wabash river at Celina, Stillwater and Wolf creeks at Dayton, and North Fork of Licking river at 
Newark, R: C. Osburn, I899; Niggermill Ru1 and Mahoning river, E. B. Williamson, I900; Cuyahoga river at Kent and Hawkins, Breakneck creek at Kent, Summit lake, Chippewa lake, Licking reservoir, Grand river at Painesville, Chagrin river at Willoughby, Wheeling creek at Bridgeport, Ohio river and McMahon's creek at Bellaire, R. C. Osburn, Igoo.

\section{Notropis ariommus (Cope).}

Head $3 \frac{3}{4}$ to $4 \frac{1}{4}$; depth $4^{1 / 4}$ to 5 . D. 8 ; A. 9; scales $6-39-2$, large, I5 before dorsal; teeth $2,4-4,2$. Body stout, moderately elevated, somewhat compressed. Head heavy, broad above; snout moderate, somewhat decurved; mouth moderate, oblique, jaws equal. Eye very large, $2 \frac{3}{5}$ in head, much longer than snout, larger than in any other Ohio Cyprinid. Lateral line much decurved. Color olivaceous, scales above dark-edged; sides and below bright silvery. Length 5 inches.

Two specimens from the Maumee river at Antwerp, Kirsch, 1893 .

\section{Notropis jejunus (Forbes).}

Head 4 ; depth $4 \frac{2}{3}$; eye $3^{2 / 3}$ in head, equal to snout, less than interorbital space. D. 8 ; A. 7 ; scales 5-37-3; teeth 2, 4-4, I. Body moderately slender; head flattish above; snout blunt and rounded. Dorsal over ventrals; about I6 scales before dorsal. Color, pale olivaceous above, pale on sides and below, with a broad silvery band overlying a plumbeous shade. Inength 3 inches.

The range of this species in the state seems to be limited to the Ohio river and the lower portions of its tributaries. HamilIon County, "common in Little Miami river and Bloody Run, Henshall, I888; common in the Ohio river and Ice creek at Ironton and in John's creek at Waterloo, R. C. Osburn, I899.

\section{Notropis atherinoides Rafinesque.}

Head $4 \frac{2}{3}$; depth $5 \frac{1}{2}$; eye $3 \frac{1}{4}$. D. 8 ; A. II; scales $5-38-3$, I5 before dorsal; teeth $2,4-4,2$. Body long and slender, compressed, back not elevated. Head blunt, conic, shorter than in related species. Mouth moderate, very oblique, upper lip on a level with upper part of pupil. Eye large, rather longer than snout. Fins low, front of dorsal midway between point of snout and base of caudal. Lateral line decurved. Color above clear, translucent olive-green, a yellow, iridescent vertebral line in life, which becomes darker in spirits; sides bright silvery, with sometimes a brassy lateral shade; breeding males with snout rosy. Length 4 to 6 inches.

* Notropis scabriceps, given by Jordan in the Ohio Rept., is confused probably with $N$. shumardi. N. scabriceps has not been noticed outside of the Kanawha river. (See Bull. 47, U. S. Nat1. Mus.) 
An elegant and graceful species, common and widely distributed, found in all larger streams, usually on gravelly or sandy bottom, and in lakes under the same conditions. Recorded for the state by Kirtland as .Minnilus dinemus. "Exceedingly common in Lake Erie, and throughout the state one of the most abundant of minnows," Jordan (Ohio Rept.); Hamilton County, "common in Clough creek," Henshall, I888; Lorain County, " very abundant at times," McCormick, I892; Maumee river at Cecil, Grand Rapids and Toledo, St. Joseph river at Edgerton, Tiffin river at Brunersburg, Auglaize river at Wapakoneta and Cloverdale, "not common at any of these places," Kirsch, I893; Franklin County, common in all of the larger streams, Williamson and Osburn, I897; Knox County, "abundant in Big Jelloway creek," Parker, Williamson and Osburn, 1898; Ohio river at Ironton, Sandusky Bay, Lake Erie at Sandusky, Ashtabula creek, Wabash river at Celina, Stillwater creek at Dayton, North Fork of Licking river at Newark, R. C. Osburn, I899 ; Cuyahoga river at Hawkins, Grand river at Painesville, Chagrin river at Willoughby, Wheeling creek at Bridgeport, Ohio river and McMahon creek at Bellaire, Licking reservoir, R. C. Osburn, I900.

\section{Notropis arge (Cope).}

Head 41/4; depth 6; eye $23 / 4$ to 3 . D. 8; A. II; scales 5-39-3. Close to $N$. atherinoides, but the eye very large, longer than snout; lateral line nearly straight, head large, the snout not very blunt; mouth large, chin projecting. Color pale-greenish olive; a dark vertebral line; belly and sides pale; a broad, silvery lateral band bounded by a dark line. Length $3 \frac{1}{2}$ inches. "Apparently varying into $N$. atherinoides, hence of doubtful validity."

This species has been taken at such points in the state as to indicate a wide distribution, but it is not generally common. Hamilton County, "common in east fork of Mill creek," Henshall, I888 ; Lorain County, "in company with $N$. atherinoides, but not nearly as common," McCormick, I892 ; Maumee river at Grand Rapids, St. Joseph river at Edgerton, Tiffin river at Brunersburg, scarce, Kirsch, I893; Cuyahoga river at Hawkins, rare, R. C. Osburn, June 25, 1900. 


\section{Notropis rubrifrons (Cope).}

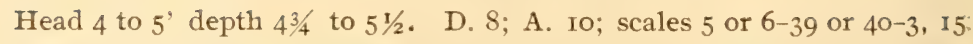
to $\mathrm{I} 7$ before dorsal (Ohio specimens run a little higher, some having as high as 20 before the dorsal); teeth 2, 4-4, 2. Body moderately elongate, back scarcely elevated, head conic and rather pointed. Eye moderate, usually shorter than snout. Resembling $N$. atherinoides, from which it can be readily told, in Ohio specimens at least, by the position of the dorsal fin, which is inserted nearer to base of caudal than to point of snout. Above clear olive, each scale dark-edged; sides and under parts silvery; a narrow, coppery lateral band in life, overlying dark pigment; a narrow vertebral line; a row of black dots on either side of anal fin. Males in spring with head and anterior parts reddish, and sometimes the bases of dorsal, ventral and pectoral fins red. Length $23 / 4$ inches.

A common and widely distributed species, found in company with $N$. atherinoides, but much more common. Kirsch and McCormick record it under the name $N$. dilectus (Girard), but $N$. dilectus, as now restricted, is found farther southwest, so I include these records under $N$. mbrifrons. Possibly the two may not be distinct. Given by Jordan as abundant in southern Ohio ; Hamilton County, " common in east fork of Mill creek," Henshall, I888; Lorain County, "common in the lake and lower parts of all streams entering it," McCormick, I892 ; St. Joseph river at Edgerton, Blanchard river at Findlay, Beaver creek at Grand Rapids, “common at these places," Kirsch, I893; Franklin County, "all larger streams with $N$. atherinoides, abundant where found," Williamson and Osburn, I897; Knox County, Big Jelloway creek and several of its tributaries, occasionally observed in large schools over clear, gravelly places in ripples, females with ripe eggs on May 24, Parker, Williamson and Osburn, I898; Ohio river at Ironton, Huron river at Milan, Sandusky Bay, Lake Erie at Sandusky, Ashtabula creek, Wabash river at Celina, Stillwater and Wolf creeks at Dayton, North Fork of Licking river at Newark, R. C. Osburn, I899; Niggermill Run and Mahoning river, E. B. Williamson, I900; Cuyahoga river at Kent and Hawkins, Grand river at Painesville, Chagrin river at Willoughby, Wheeling creek at Bridgeport, Ohio river and McMahon's Run at Bellaire, outlet of Licking reservoir, R. C. Osburn, I900. 
Notropis umbratilis lythrurus (Jordan), REDFIN.

D. 7; A. II ; teeth 2, 4-4, 2; scales 9-45-3, crowded anteriorly. Head pointed, about 4 in length; body moderately elongated, compressed, depth 4 to 5 . Eye $3 \frac{1}{2}$. Color bright steel-blue above, pale below. Dorsal fin with a conspicuous black spot at base in front. Breeding males have the lower fins bright red. Females and young paler. Length 3 inches.

An exceedingly handsome species, especially during the breeding season. Widely distributed and generally common. Recorded for the state by Kirtland as Semotilus diplema. Jordan gives it under the name Lythrurus diplaemius as "abundant throughout the state, especially in the southern part "; Henshall, Kirsch and McCormick record it under the name $N$. ardens; "abundant in all streams examined," in Hamilton County, Henshall, I888; " found at all points explored in Maumee river system in Ohio except Maumee river at Cecil and Toledo, St. Joseph river at Edgerton and St. Mary's river at Rockford, Kirsch, I893; Lorain County, "not very common, Black river and Vermillion river near Klipton," McCormick, I892 ; Franklin County, "all streams but the smallest, abundant,"' June I 5 given as a breeding date, Williamson and Osburn, I897; Ice creek at Ironton, Huron river at Milan, Ashtabula creek at Ashtabula, Wabash river at Celina, Stillwater and Wolf creeks at Dayton, North Fork of Licking river at Newark ; exceedingly abundant in a small tributary of Ashtabula creek, in company with Abramis crysoleucas, R. C. Osburn, I899; Niggermill Run at Salem, E. B. Williamson, I900; Breakneck creek near Kent, Grand river at Painesville, Chagrin river at Willoughby, Wheeling creek at Bridgeport, Ohio river and McMahon creek at Bellaire, R. C. Osburn, Igoo.

\section{Genus: Ericymba.}

Ericymba buccata (Cope). Silfery-JAWED Minnow.

Head $3 \frac{1}{2}$ to 4 ; depth $4 \frac{1}{2}$ to 5 ; eye 4 to $4 \frac{1}{2}$. D. 8 ; A. 7 ; scales 4 or 5 $34-3$, about $\mathrm{I} 5$ in front of dorsal; teeth $\mathrm{I}, 4-4$, I or I, 4-4, $\mathrm{O}$, the inner slender and without grinding surface. Body rather elongate, little compressed, back not elevated. Head long, depressed above, with broad and prominent muzzle. Mouth small, horizontal, sub-inferior, lower jaw the shorter. Interopercle, suborbital and dentary bones containing mucous cavities, 
which are visible externally. Color olivaceous above, pale and silvery on sides and below; a dark vertebral line and sometimes an indistinct, dark lateral band. Fins all plain. Length 3 to 5 inches.

Distributed throughout the state, a very common species, less abundant in the lake than in the Ohio river drainage. "Abundant in most streams tributary to the Ohio,' Jordan's Report ; Hamilton County, " abundant in Little Miami river and tributaries," Henshall, I888 ; Lorain County, "taken once in Black river," McCormick, I892 ; the Maumee river system in Ohio except at the following places: Maumee river at Cecil, Tiffin river at West Unity and Brunersburg, Auglaize river at Wapakoneta and Lost creek at Lima, Kirsch, r893; Franklin County, every stream, generally abundant, June I5 given as a breeding date, Williamson and Osburn, I897; Big Jelloway creek system, Knox County, "taken in every stream, abundant," Parker, Williamson and Osburn, I898; Ohio river and Ice creek at Ironton, Huron river at Milan, Wabash river at Celina, Stillwater and Wolf creeks at Dayton, North Fork of Licking river at Newark, R. C. Osburn, I899; Niggermill Run and Mahoning river, E. B. Williamson, I9oo; Cuyahoga river at Hawkins, Chippewa lake, Grand river at Painesville, Chagrin river at Willoughby, Wheeling creek at Bridgeport, Ohio river and McMahon's Run at Bellaire, Licking reservoir, R. C. Osburn, I 900 .

\section{Genus: Rhinichthys.}

Key to Species.

A. Suout long and prominent, projecting much beyond the mouth, barbel evident, no distinct, black lateral band.cataracta.

AA. Snout shorter, little projecting, barbel small, but always present; a distinct, black lateral band.atronasus.

Rhinichthys cataractæ (Cuvier and Valenciennes). LONG-NOSED DACE.

Head 4 ; depth 5 ; eye 2 in snout, 5 in head. D. 8; A. 7 ; scales small, I4-65-8; teeth 2, 4-4, 2. Resembling $R$. atronasus, from which it is distinguished by the longer head, by the prominent overhanging muzzle, much longer than in atronasus, by the longer barbels and by the absence of a distinct, dark lateral band. Color dark-brownish olive above, sometimes slightly mottled; paler below; a dark spot on opercle, but no distinct band through eye or along side. Length 5 inches. 
Apparently a rare species in Ohio. Dr. Jordan (Ohio Rept.) says: "It is found in the tributaries of Lake Erie and even in the lake itself. It also occurs in the southeastern part of the state." Since then it has not been noticed by any other collector, and the writer has taken it but once, a single specimen from a small tributary of the Grand river near Painesville, August 2, I900.

\section{Rhinichthys atronasus (Mitchil1), BLACK-NOSED DACE.}

Head 4 ; depth $4 \frac{1}{2}$; eye $I^{1 / 2}$ in snout, $4^{1 / 2}$ in head. D. 7 or 8 ; A. 7 ; scales I0-65-6; teeth $2,4-4,2$. Body moderately elongate, little compressed. Head moderate, rather broad and flattish above; snout moderate; mouth horizontal, lower jaw included; barbels well marked in all Ohio specimens. examined. Color above dark-yellowish olive, much blotched with black; a black lateral band passing forward through eye to snout; breeding males have the lateral band and the lower fins bright orange or crimson. All color markings less evident in females and young, but the lateral, dark band always present.

Distributed over the state and generally common or even abundant in suitable localities. It is essentially a "brook" species, being rarely found in larger streams, but swarming in clear, cold spring runs, in company with Chrosomus erythrogaster. Hamilton County, "common in all the streams," Henshall, i 888 ; Lorain County, "Spring brook and Chance creek, not common," McCormick, I892; Maumee river system, "several from Lost creek near Cecil, by Prof. Meek, found nowhere else" (in Ohio), Kirsch, 1893; Franklin County, Grant's Run and Plum Run, common, Williamson and Osburn, I897; Knox County, Little Jelloway creek, Parker's Run, Joe Sapp Run and Shadley Run, tributaries of Big Jelloway creek, common or abundant, May 24 given as a breeding date, Parker, Williamson and Osburn, I898; Ohio river at Ironton, Huron river at Milan, Wabash river at Celina, Wolf creek at Dayton, North Fork of Licking river at Newark, in all of these cases the species has been taken in small nameless tributaries rather than in the main stream, with the exception of Wolf creek and the Ohio river, R. C. Osburn, I899; Cuyahoga river at Kent and Hawkins, and Breakneck creek near Kent, R. C. Osburn, I90o. 


\section{Genus: Hyвоpsis.}

Key to Species.

A. Mouth inferior, horizonta1, color silvery.

B. Teeth one-rowed, 4-4.

C. Eye $3^{T / 4}$ in head; no plumbeous blotches along lateral line.-hyostomus.

CC. Eye very large, $2 \frac{3}{4}$; an interrupted plumbeous lateral band.-dissimilis.

BB. Teeth two-rowed, I, 4-4, I, or I, 4-4, o.

D. Sides with a dusky lateral band.-

DD. Sides silvery, no lateral band.-

AA. Mouth large, nearly terminal; eye small; not silvery.-

amblops.

storerianus.

kentuckiensis.

\section{Hybopsis hyostomus (Gilbert).}

Head 4 ; depth $5 \frac{1}{2}$; eye $3 \frac{1}{4}$. D. 8 ; A. 8 ; scales in lateral line $37, I_{3}$ before dorsal. Body and head very slender; snout long, acute, projecting beyond mouth for half its length; mouth short, wide, inferior; barbels long. Color silvery, everywhere dusted with fine, dark specks. Length $2 \frac{1}{2}$ inches.

Very rare in the state, and, as far as my knowledge goes, confined to the Ohio river. Dr. Henshall recorded it first from the Ohio river at Raccoon Island, I889, and the writer has taken it twice in the Ohio, at Ironton, May 3I, I899, and at Bellaire, August 3I, I900.

\section{Hybopsis dissimilis (Kirtland). SPOTTED SHINER.}

Head $4 \frac{1}{2}$; depth 5 . D. 8 ; A. 7 ; teeth $4-4$; scales $6-40$ to $47-5$, about 20 in front of dorsal. Body long and slender, little compressed, with long caudal peduncle. Head long, flattish above; snout somewhat bluntly decurved, a little projecting; mouth small, horizontal, lower jaw included; barbel smaller than in $H$. amblops; eye about 3 in head, somewhat directed upward. Color above dusky or olivaceous, somewhat mottled; sides silvery, with a bluish lateral band, which is sometimes widened into several blackish blotches. In full coloration, one of the most striking of our Minnows.

This species has been taken in a number of localities in Ohio, and in both the lake and Ohio river drainage, but is nowhere common. Recorded by Kirtland for the Mahoning river and Lake Erie near Cleveland; Hamilton County, "rather common in Little Miami river and O' Bannon creek,' Henshall, I888 ; Franklin County, "Big Walnut creek, rare," Williamson and Osburn, I897 ; Stillwater creek near Dayton, rare, R. C. Osburn, I899; Cuyahoga river at Hawkins, R. C. Osburn, Isoo. 


\section{Hybopsis amblops (Rafinesque). SILVER CHUB.}

Head 4 ; depth $4 \frac{1}{2}$ to 5 ; eye 3 . D. 8 ; A. 7 or 8 ; scales $5-38-4$, about I4 before dorsal; teeth I, 4-4, I. Body rather slender, little compressed, rather heavy anteriorly. Head large, flattened and broad above; mouth subinferior, horizontal; barbel evident. Lateral line somewhat decurved. Color above clear translucent green, scales dark-edged; sides with a broad, silvery lateral band, overlying dark pigment, which sometimes appears as a dark lateral band; a dark band through eye around snout. Fins all plain. Length about 3 inches.

Common or abundant throughout the state, found in nearly all streams, but not taken in lakes. Recorded by Kirtland. Given by Jordan as abundant in tributaries of the Ohio ; Hamilton County, "common in Little Miami river," Henshall, I888; Lorain County, "common in some of the streams," McCormick, I892 ; Maumee river system, "all the smaller tributaries," Kirsch, I893; Franklin County, common in all but the smallest streams, Williamson and Osburn, I897; Big Jelloway creek, Knox County, abundant, Parker, Williamson and Osburn, I898; Ohio river at Ironton, John's creek at Waterloo, Huron river at Milan, Ashtabula creek at Ashtabula, Wabash river at Celina, Stillwater and Wolf creeks near Dayton, North Fork of Licking river near Newark, R. C. Osburn, I899; Cuyahoga river at Hawkins, Grand river at Painesville, Chagrin river at Willoughby, Wheeling creek at Bridgeport, Ohio river and McMahon's creek at Bellaire, R. C. Osburn, I90o.

\section{Hybopsis storerianus (Kirtland).}

Head $4 \frac{1}{2}$; depth 4 ; eye 3 , equal to snout. D. 8; A. 8; scales 5-42-4. Body elongate, somewhat compressed, the back somewhat elevated. Head short, compressed; preorbital bone large and silvery; mouth horizontal, lower jaw included; barbels conspicuous. Lateral line somewhat decurved. Dorsal inserted over ventrals, ventrals not reaching vent, caudal long, deeply forked. The teeth are said to be usually I, 4-4, o, but all Ohio specimens examined have the teeth I, 4-4, I. Translucent greenish above; elsewhere bright silvery, sides with a slight plumbeous lateral band, no caudal spot. Length 5 to ro inches.

Apparently not well distributed over the state, though occurring in both the Lake Erie and the Ohio river drainage. Lake Erie, Kirtland; " abundant in Lake Erie," Jordan ; Hamilton 
County, "common in Little Miami river and Clough creek," Henshall, I888; Lorain County, Beaver creek and Lake Errie, McCormick, I892 ; Lake Erie near Sandusky, R. C. Osburn, 1900. Dead ones are frequently thrown upon the beach by the waves at Sandusky; not noticed in Sandusky Bay.

Hybopsis kentukiensis (Rafinesque). HORNY-HEAD; River Chub; JeRker; INdian Chub.

Head $3 \frac{3}{4}$ to 4 ; depth 4 to $4 \frac{1}{4}$; eye $5 \frac{1}{4}$. D. 8 ; A. 7 or. 8 ; scales $6-4 \mathrm{I}-5$, about I 8 before dorsal; teeth I, 4-4, I or I, 4-4, o, sometimes 4-4, in all Ohio specimens examined they are I, 4-4, I. Body rather robust, little elevated, little compressed. Head large, broadly rounded above; snout conical, bluntish; mouth large, nearly terminal; barbel evident. Dorsal inserted slightly behind ventrals. Color dusky or bluish or greenish olive above, sometimes with brassy luster, pale but not silvery below; sometimes with a clear, grass green lateral band in life; fins all plain, tinged with dull orange. Breeding males have the belly tinged with rosy, and a crimson spot on side of head behind eye, and have the top of the head swollen into a crest which is covered with tubercles. Young with dark caudal spot. Length 6 to 9 inches.

Well distributed over the state and generally common. Recorded by Kirtland. "Every stream in the state of Ohio," Jordan; Hamilton County, "Little Miami river," Henshall, I888 ; Lorain County, " very common in larger streams," McCormick, I892; Maumee river system in Ohio, "every point in every stream examined," Kirsch, I893 ; Franklin County, common in larger streams, July I6 given as breeding date, Williamson and Osburn, I897; Big Jelloway creek system, Knox County, abundant, May 23 noted as a breeding date, Parker, Williamson and Osburn, I898, Ohio river at Ironton, Huron river at Milan, Ashtabula creek at Ashtabula, Wabash river at Celina, Stillwater and Wolf creeks at Dayton, North Fork of Licking River at Newark, R. C. Osburn, I899; Cuyahoga river at Kent and Hawkins, Grand river at Painesville, Chagrin river at Willoughby, Wheeling creek at Bridgeport, Ohio river at Bellaire, R. C. Osburn, I900.

\section{Genus: Exoglossum.}

Exoglossum maxillingua (Le Sueur). CUT-LIPS; NigGER ChUb.

Head 4 ; depth $4 \frac{1}{2}$. D. 8; A. 7 ; scales $8-53-5$; teeth I, 4-4, I. Body rather stout, little compressed. Head broad and flattish above, with tumid cheeks. Mouth peculiar, the mandible being contracted and incurved, its. 
outline 3 -lobed; this appearance is due to the fact that the dentary bones lie close together, parallel, and are united throughout their length, instead of forming an arch as in all other Cyprinide; lower lip represented by a broad, fleshy lobe on either side of the mandible. Color olivaceous, smoky or dark above; a blackish bar behind opercle, and a dusky shade at base of caudal in young. Fins all plain. Length 6 inches.

Rare in Ohio. Six specimens were taken by the writer in Stillwater creek near Dayton, Aug. I5, I899. The range of the species is to the eastward. West of the Alleghenies it has heretofore been known only from the Kanawha river, West Virginia.

\section{Order: AFODES.}

\section{Sub-Order: ENCHELYCEPHALI.}

\section{Family: ANGUILLIDE⿸ \\ Genus: Anguilia.}

\section{Anguilla chrysypa Rafinesque. AMERICAN ĖEL;}

FRESHWATER EEI.

Body elongate, compressed behind; appearing scaleless, but covered with fine, imbedded scales. Head long, conical, moderately pointed. Dorsal and anal fins confluent with caudal. Color brown, often tinged with yellowish; paler below, the color quite variable. Length 4 or 5 feet.

The Eel appears to be nowhere very common in Ohio, but is widely distributed throughout the state, and probably occurs in every lake, reservoir and large stream. Rafinesque mentions its occurrence in the Ohio " as far as Pittsburg ;" Kirtland records it for the Ohio river drainage; Lake Erie and Ohio river, Henshall, I 889 ; Lorain County, "occasionally taken in the pounds," McCormick, I892; Maumee river at Defiance, "said to inhabit all waters of the Maumee basin, "' Kirsch, I893 ; Franklin County, observed in Big Walnut creek, reported by fishermen as "not rare," Williamson and Osburn, I897 ; Pippin lake and Chippewa lake, R. C. Osburn, I900. I have seen specimens taken in Licking reservoir, Licking river and North Fork of Licking river. According to Kirtland the Eel did not formerly inhabit the Lake Erie drainage, but if not, it has found its way there through the canals. 


\title{
()rder: ISOSPONDYLI.
}

\section{Family: HIODONTIDAs.}

\author{
Genus: Hiodon.
}

\section{Key to Species.}

A. Belly in front of ventrals carinated; dorsal with g developed rays.- alosoides AA. Belly in front of ventrals not carinated; dorsal of II or 12 developed rays-tergisus.

\section{Hiodon alosoides (Rafinesque).}

Head $4 \frac{1}{2}$; depth $3 \frac{1}{2}$; eye $3 \frac{1}{2}$. D. 9; A. 32; scales 6-56-7. Body closely compressed, becoming deep in the adult, the ventral edge everywhere carinated. Maxillary reaching middle of eye. Caudal peduncle rather stouter than in $H$. tergisus, and the fin not so deeply forked; also, the pectorals are longer and the ventrals shorter than in $H$. tergisus. Color bluish, sides silvery, with golden luster. Length 12 inches.

Rare in Ohio, the range of the species being farther to the west. A single specimen, taken in a fisherman's net in the Ohio river, was recorded by Henshall for Hamilton County, I 888.

\section{Hiodon tergisus Le Sueur. Moon Eye; Toothed HerRing.}

Head $41 / 3$; depth 3 ; eye 3 . D. I2; A. 28 ; scales $5-55-7$. Body oblong, moderately compressed. Eye large, the maxillary barely reaching its middle. Pectoral fins not reaching ventrals, the latter just short of vent. Belly somewhat carinated behind ventrals only. Color brilliantly silvery, oliveshaded above. Length 12 inches.

This species is confined to Lake Erie and the Ohio river, and the lower courses of their larger tributaries, but it is common where found. Rafinesque made four species of it, and reported two of them for the Ohio as far as Pittsburg. Three of these nominal species, $H$.clodalus, $H$. vernalis and $H$. tergisus, were recognized by Kirtland in his 1838 report, but he afterward dropped all but H. tergisus. " CCommon in the Ohio," Henshall, I888; Lorain County, "common in the lake, ascending the streams sometimes," McCormick, I892; " below the dams in the Maumee river at Defiance and Grand Rapids, at both places they were very abundant,' Kirsch, I893 ; Ohio river at Bellaire, R. C. Osburn, I 900. 


\section{Family: Dorosomides.}

\section{Genus: Dorosoma.}

\section{Dorosoma cepedianum (Le Sueur). Gizzard SHAD.}

Head $4 \frac{1}{3}$; depth $2 \frac{1}{2}$; eye $4 \frac{1}{2}$. D. 12 , its last ray prolonged and filiform, about as long as head; scales 56-23. Body deep, compressed, the back elevated in adult; belly compressed to an edge, serrated and covered by scutes, I 7 in front of vent, I 2 behind. Mouth small, inferior, no teeth. An adipose eyelid. No lateral line. Stomach short, muscular, like the gizzard of a fowl. Caudal fin widely forked, lower lobe the longer. Color silvery-bluish above; young with a round, dark spot at shoulder; tips of ventrals and edge of anal often dusky. Length 15 inches.

This handsome, worthless species is now well distributed over the state in the lake and larger streams, although it is said that previous to the opening of the canals it was not found in the lake drainage. The form resident in the Mississippi valley is known as var. heturum. Given by Kirtland as Chatoessus ellipticus. Ohio river, Lake Erie and Licking reservoir, Jordan's Report ; Hamilton County, "very common in the Ohio river," Henshall, I888 ; Lorain County, "quite common in the lake and ascending the rivers," McCormick, I892; Maumee river at Defiance and Grand Rapids, St. Mary's river at St. Mary's and Rockford, Tiffin river at Brunersburg, Auglaize river at Cloverdale, Oakwood and Defiance, Hoaglin creek near Oakland and Gordon creek near Cecil, Kirsch, I893; abundant in St. Mary's reservoir and in the wasteway of the St. Mary's reservoir into the headwaters of the Wabash river at Celina, R. C. Osburn, I899; Chippewa lake, Ohio river at Bellaire and Licking reservoir, very abundant at the last place, R. C. Osburn, I9oo.

\section{Family: CLUPEIDAE. \\ Genus: Pomolobus.}

\section{Pomolobus chrysochloris Rafinesque. SKIPJACK ; BLUE HERRING.}

Head $3 \frac{3}{4}$; depth $3 \frac{3 / 4}{\text {; }}$ eye shorter than snout, large, well covered by an adipose eyelid, $4 \frac{1}{3}$ in head. D. I6, its posterior ray not prolonged; A. I8; about 52 scales in lateral line. Body elliptical, much compressed; belly compressed to an edge which is covered with scutes, 20 before vent, I 3 
behind. Head slender and pointed; lower jaw strongly projecting; upper jaw emarginate. Color, brilliant blue above, sides silvery with golden reflections; no dark spot behind opercle. Length ${ }_{5} 5$ inches.

This is a deep water species, common in the Ohio river, and it has made its way through the canals into Lake Erie, where it is now said to be common. Ohio river, "seldom as far as Pittsburg," Rafinesque; "very rare, two specimens seen in Cincinnati market,' Kirtland, I838 ; Hamilton County, " abundant in Ohio river,' Henshall, I 888.

\section{Family: SALMONID死. \\ Key to Genera.}

A. Mouth not deeply cleft; dentition feeble or incomplete, scales large.

B. Lower jaw short and more or less included, cleft of mouth short.-

COREGONUS.
r long.-

AA. Mouth deeply cleft; dentition strong and complete, scales small.

C. Vomer with raised crest, which is armed with strong teeth; hyoid bone with a broad band of strong teeth; no bright colors.- CRIstivomer.

cC. Vomer without raised crest; hyoid with weak teeth or none; spotted with red.-

SALVELINUS.

\section{Genus: Coregonus.}

Coregonus clupeiformis (Mitchill). CoMmon WhiTEFish.

Head 5 ; depth 3 to 4 ; eye 4 to 5 . D, II; A. II; scales 8-74 to 85-9. Body oblong, compressed, always elevated, especially so in adult. Head comparatively small and short; the snout obliquely truncated. Gill rakers numerous, long and slender. Color olivaceous above; sides white, but not silvery; lower fins sometimes dusky. Length 2 feet or more.

In Ohio the Whitefish is found only in Lake Erie, where it occurs in great numbers. It does not ascend streams. Recorded first by Kirtland. "The most important fish of Ohio, both as to quantity taken and quality as food,' Jordan's Report; L. Erie, Henshall, I889; "common in the lake," McCormick, I892; " west end of Lake Erie,", Kirsch, I 893. Great quantities from various parts of the lake are brought into the fish houses at Sandusky. 


\section{Genus: Argyrosomus. \\ key to Species.}

A. Lower jaw projecting; depth in length $4 \frac{1}{2}$.-

AA. Jaws about equal; depth in length 3 to $3^{\frac{1}{2}} /$.-

artedi.

tullibee.

Argyrosomus artedi (Le Sueur). CiSCO; LAKE HERRING.

Head $4 \frac{1}{2}$; depth $4 \frac{1}{2}$; eye 4 to $4 \frac{1}{2}$. D. IO; A. I2; scales $8-75$ to $90-7$. Body elongate, compressed, not elevated. Head compressed, rather long; distance from occiput to snout usually a little less than half the distance from occiput to insertion of dorsal fin. Dorsal fin high, its rays rapidly shortened. Bluish black or greenish above; sides silvery, with dark specks; fins mostly pale, the lower dusky-tinged. Length I foot.

In Ohio taken only in Lake Errie, where it is very abundant. Recorded by Kirtland, Jordan and Henshall. Lorain Co., "very abundant, sometimes filling the pound nets almost solid with fish," McCormick, I892; " west end of Lake Erie," Kirsch, I893. Brought into Sandusky fish houses in enormous numbers.

Argyrosomus tullibee (Richardson). TULLIBEE; MongreL

WHITEFISH.

Head 4 to $4 \frac{1}{2}$; depth 3 to $3 \frac{1}{5}$; eye $4 \frac{1}{2}$, as long as snout. D. II or I2; A. II; scales 8 or $9-67$ to $74-8$. Body short, deep, compressed, shad-like, dorsal and ventral curves similar. Head conic, compressed; distance from occiput to tip of snout half the distance from occiput to insertion of D. Color bluish above; sides white, punctate with fine dots; each scale with a silvery area, these forming a series of distinct longitudinal stripes. Length I8 inches.

I have seen but one record of this species in Ohio, as follows: "I once received a photograph of a Tullibee from Dr. E. Sterling, of Cleveland. The specimen had been taken in Lake Erie," Jordan's Report.

\section{Genus: Cristivomer.}

Cristivomer namaycush (Walbaum). MACkINAW TrouT; GREAT LAKE TROUT; NAMAYCUSH.

Head 41/4; depth 4 ; eye large, 41/2. D. II; A. II; lateral line 185 to 205 . Body elongate. Head very long and pointed, its upper surface flattened. Mouth very large, the maxillary extending much beyond eye; teeth strong. Caudal fin well forked; adipose fin small. General color dark gray, varying from pale to nearly black; everywhere with rounded, paler spots, which are often reddish tinged; dorsal and caudal reticulate with darker. Length 3 feet. 
In Ohio taken only in Lake Erie, does not ascend streams. Kirtland records it for Lake Erie, " a few stragglers are taken." Jordan and Henshall also record it. McCormick says of its occurrence in Lorain County, "very rare, it is almost unknown to the fishermen here, though common in the eastern part of the lake."

\section{Genus: Salvelinus.}

\section{Salvelinus fontinalis (Mitchill). SPECKLED TrouT; Brook TrouT.}

Head $4 \frac{1}{2}$; depth $4 \frac{1}{2}$. D. IO; A. 9; scales 37-230-30. Body oblong, moderately compressed, not much elevated. Head large, but not very long, the snout bluntish; mouth large, the maxillary reaching more or less beyond eye; eye large. Color above more or less mottled with dark olive or black: sides in life with many red spots; dorsal and caudal mottled or barred with dark; belly in males often more or less red.

The Brook Trout now probably occurs in but one stream in the state, Castalia creek, near Sandusky. In I838 Kirtland recorded the species as found "in only two streams, a small creek in Ashtabula County, and a branch of the Chagrin river in Geauga County.' In I889 Henshall recorded it for Castalia creek. It still occurs there in numbers under the protection of a fishing club, which, I understand, introduces young fry to keep up the supply.

\section{Order: H.APLOMI. \\ Family: UMBRID死. \\ Genus: UinsRA.}

Umbra limi (Kirtland). Mud Minnow.

Head $3 \frac{3}{4}$; depth $4 \frac{1}{4}$. D. I4; A. 8; scales $35^{-15}$, soft and leathery; no lateral line. Body oblong, compressed. Head large, shortish, cheeks and opercles and top of head forward to between the eyes, covered with scales. Caudal fin conspicuously rounded. Color dull olive green, with a dark dorsal band and about 44 light vertical bars, less distinct in young. A dark bar at base of caudal. Length $4 \frac{1}{2}$ inches.

This species is rare in the Ohio river drainage, but is reported as very common in the northern part of the state. Recorded for streams of northern Ohio by Kirtland; abundant in the northern part of Ohio, Jordan's Report; Lorain County, "very common in sloughs and bayous,' McCormick, I892 ; Fish creek at Edger- 
ton, Lost and Gordon creeks near Cecil, "very common on soft muddy bottom," Kirsch, I893; a single specimen was taken April 3, I897, in a small tributary of the Olentangy river at Columbus by Mr. E. B. Williamson and the writer; Niggermill Run at Salem, E. B. Williamson, I900; abundant in the "Black Channel"' in Sandusky Bay, R. C. Osburn, I9oo.

\section{Family: LuCIID死 \\ Genus: Lucius. \\ Key to Species.}

A. Opercles entirely scaled, scales in lateral line ro5.AA. Opercles with the lower half bare of scales.

B. Cheeks entirely scaled, scales in lateral line about I23.-

vermiculatus.

BB. Cheeks with the lower half bare of scales, scates in 1 masquinongy.

\section{Lucius vermiculatus (Le Sueur). LITTLE PICKEREL; GRASS PIKE,}

Head long, $3 \frac{1 / 4}{4}$ to $3 \frac{3 / 4}{4}$ in length of body; depth 5 to 6 ; eye 6 in head, large. D. II or I2; A. II or I2; scales I05. Body elongate, somewhat compressed. Opercles and cheeks entirely covered with scales. Color greenish or grayish olive, everywhere reticulated with irregular, light markings; the color extremely variable. Length about a foot.

The Little Pickerel, or "Grass Pike," as it is sometimes called, is common throughout the state in suitable localities. Its favorite haunt is the weedy pond or backwater or overflow pool of some stream, and in such places it is sometimss very abundant. Jordan in his Ohio Report gives it as more abundant in the Ohio river drainage than in that of the lake. "Lake Erie and Maumee river," Henshall, I889 ; Lorain County, "common," McCormick, I892 ; "common throughout the Maumee basin, all waters examined (in Ohio) except Hoaglin creek," Kirsch, I893 ; Franklir County, "of general distribution, abundant in Hell Branch," Williamson and Osburn, I897 ; John's creek at Waterloo, Huron river at Milan, Ashtabula creek at Ashtabula, R. C. Osburn, I899; Sandusky Bay, Breakneck creek near Kent. Licking reservoir, R. C. Osburn, I900.

Lucius lucius (Linnaeus). PICKEREL; PIKE.

Head $3 \frac{1}{3}$; depth 5 ; eye $6 \frac{1}{3}$ in head. Developed rays of dorsal 16 or 17 , of anal I3 or I4; scales I23. Body moderately elongate, back little elevated. Head rather long. Cheeks scaly; the lower half of opercle bare. Color 
bluish or greenish gray, with many whitish or yellowish spots arranged' somewhat in rows. Dorsal, anal and caudal fins with roundish or oblong, black spots. Length 4 feet.

The Pickèrel is said to have been very abundant at one timein all the streams flowing into Lake Erie and somewhat less. common in the Ohio river drainage. In the latter it has now, as. far as Ohio is concerned, become quite rare, and in the lake drainage, and even in the lake itself, it has noticeably diminished in numbers. Kirtland gives it as "common both to the waters. of the Ohio and the lake." Lake Erie and Sandusky river, Henshall, I889; Lorain County, Lake Erie and Black river, "often killed in the ponds and channels of the snipe ground when they are spawning," McCormick, I892 ; St. Joseph river at Edgerton, Tiffin river at West Unity and Brunersburg, Auglaize river at Cloverdale, Kirsch, I893; Sandusky Bay, R. C. Osburn, I899; Licking reservoir, a single specimen, I I $/ 2$ feet in length. R. C. Osburn, I900.

\section{Lucius masquinongy (Mitchill). MUSKALLUNGE.}

Head $32 \frac{2}{3}$; depth 6 ; eye 4 to 6 in snout. D. I7; A. 15 ; scales 150. General form of $L$. lucius; the head proportionately longer. Cheeks and opercles both naked below. Color dark gray, sides in the typical form, masquinongy, with round or squarish, blackish spots of varying size on a ground color of grayish silvery; belly white; fins spotted with black. Length 4 to. 8 feet.

This magnificent Pike is represented in Ohio by two varieties, as follows: L. masquinongy var. masquinongy, the typical form, confined to Lake Erie and its tributary rivers, and L. Masquinongy ohiensis (Kirtland), confined to the Ohio river and its tributary streams. The variety ohiensis is separated from the typical form by the presence of narrow irregular crossbars, formed by the coalescing of spots on the sides. Kirtland records the former for Lake Erie and the Ohio canal near Massilon, I838, and the latter for the Mahoning river, I854; Ohio river and Lake Erie, Henshall, I889; McCormick records the species. for Lorain County, and states that it is growing rare, being seldom taken in the pounds; Kirsch, in I893, speaks in the same strain of their diminishing numbers in Maumee river and the west end of Lake Erie. 


\section{Family: PCECILIIDA. \\ Genus: Fundulus. \\ Key to Species.}

A. No broad, black lateral band.

B. Dorsal fin of 12 or $\mathrm{I} 3$ rays.- diaphanus.

BB. Dorsal fin of 7 rays.- dispar.

AA. A broad, black lateral band, its ed es notched; dorsal fin of 9 rays.- notatus.

Fundulus diaphanus menona (Jordan and Copeland).

Head $3 \frac{1}{2}$; depth 5. D. I2; A. Io; scales 48-I2. Body rather slender, not elevated, compressed posteriorly. Head flattened above. Fins rather small and low. General color olivaceous, below pale, sides somewhat silvery; back always spotted; sides with about I6 distinct, irregular, dark bands, these often replaced by the same number of shining, silvery bands narrower than the interspaces. Length $3 \frac{1}{2}$ inches.

Taken only in the northern part of the state, where in suitable places it is common. "Taken once near Lorain, common near Huron and Put-in-Bay," McCormick, I892 ; "Maumee river at Toledo, abundant," Kirsch, I893; noted commonly by Prof. D. S. Kellicott, E. B. Williamson and the writer in Sandusky Bay in I896, and again by the writer in 1899 and 1900.

\section{Fundulus dispar (Agassiz).}

Head $3 \frac{3}{4}$; depth $31 / 2$. D. 7 ; A. 9; scales 35-10. Body short and deep, much compressed. Head short and very broad, the distance between the eyes above greater than the distance between them below. Snout broadly rounded. Dorsal fin much smaller than anal. Color pale olive, bluish in life; about Io longitudinal, wavy, brown stripes along sides formed by the dark edges of the scales. Males have these stripes interrupted and have about 9 dark crossbars; a black blotch below eye. Length $2 \frac{1}{2}$ inches.

Given for Ohio by Jordan (Ohio Rept.), and Jordan and Evermann (Bull. 47, U. S. Nat1. Mus.) Dr. B. W. Evermann, in a recent letter regarding this species, says : "I learned of its occurrence in the Celina reservoir through students of mine who seined there. No record was published, however.'"

Fundulus notatus (Rafinesque). TOP MrNnow.

Head 4; depth $4 \frac{1}{2}$; eye 3 . D. 9; A. II or I2; scales $34-$ II. Body slender, compressed posteriorly. Head depressed, rather long, the snout somewhat produced; interorbital space half the length of head. Color olivaceous or brownish olive, with a broad, blackish lateral band from tip of 
snout to caudal, this band usually notched above and below, giving it a serrated appearance. A light, translucent spot is conspicuous on the top of the head when the fish is swimming at the surface. Length 2 to $3 \frac{1}{2}$ inches.

The Top Swimmer is a common species in suitable localities in the Ohio river drainage, but is rather rare in the tributaries of the lake. Hamilton County, very abundant in Ross lake, Henshall, I888; Maumee river at Grand Rapids, St. Mary's river at St. Mary's and Rockford, Tiffin river at West Unity and Brunersburg, Auglaize river at Wapakoneta, Cloverdale, Oakwood and Defiance, Blanchard river at Ottawa, Hoaglin creek at Ottawa, " seemingly scarce at all these points," Kirsch, I893; Franklin County, of general distribution, abundant in places, Williamson and Osburn, I897; Wabash river at Celina, Stillwater creek near Dayton, very common, R. C. Osburn, I899.

\section{Order: HEMIBRANCHII.}

\section{Family: GASTEROSTEIDA.}

\section{Genus: Eucalia}

\section{Eucalia inconstans (Kirtland). BROOK STICKLEBACK.}

Head $3 \frac{\pi}{2}$; depth 4 . D. IV-I, IO; A. I, IO. Body moderately elongate, little compressed; caudal peduncle slender, not keeled. Dorsal spines low, subequal, 4 or 5 in number in a right line; a cartilaginous ridge along base of fin; ventral spines short and sharp, serrated. Color, males in spring jet black, tinged with red anteriorly; females and young, olivaceous, mottled and dotted with black. Length $2 \frac{1}{2}$ inches.

This species is probably confined to the central and northern parts of Ohio. It is said to be abundant in some localities. Kirtland described the species in $\mathrm{I} 84 \mathrm{I}$, from brooks of Trumbull County; Jordan gives it as "abundant in many streams in northern part of Ohio " ; "Castalia creek " near Sandusky, Henshall, I889; Lorain County, "I have found sticklebacks in but two places," McCormick, I892; Mr. E. B. Williamson writes me that he has found the species in Niggermill Run at Salem, Columbiana County, 1899. 


\title{
Order: ACAN'THOPTERI.
}

\author{
Sub-Order: SAlMOPERCA. \\ Family: PERCOPSIDE. \\ Genus: Percopsis.
}

\section{Percopsis guttatus Agassiz. TROUT PERCH.}

Head $3 \frac{x}{2}$ to 4 ; depth 4 to $4 \frac{1}{2}$. D. II, 9; A. I, 7 ; scales about 50 , strongly ctenoid. Head rather long, slender and conical, mouth subinferior. Body rather slender; caudal peduncle long and slender. A small but distinct adipose fin behind dorsal. Color, pale olivaceous on back, colorless and somewhat translucent below; about II small, dark spots along lateral line, and another row of smaller dots between this and mid-dorsal line. Length 4 to 6 inches.

Jordan and Evermann (Bull. 47, U. S. Nat1. Mus.) in discussing the range of this species give it as "rare in streams south of Lake Erie."' This statement does not seem to hold good for the State of Ohio, for in suitable localities the species is common as far as the southern limits of the state, and in some places is very abundant. Hamilton County, "abundant in Little Miami river below the dam at Loveland," Henshall, I888; Lorain County, " common in Lake Erie, Black river and Beaver creek," McCormick, I892 ; Franklin County, taken in most of the streams of the county, abundant in streams west of the Scioto, after some hauls in Scioto Big Run the seine contained more of this than all the other species combined, Williamson and Osburn, I 897 ; John's creek at Waterloo, Huron river at Milan, common at both places, R. C. Osburn, I899; Ohio river at Bellaire, R. C. Osburn, I900.

\section{Sub-Order: XENARCHI.}

\section{Family: APHREDODERIDE. \\ Genus : Aphredoderus.}

Aphredoderus sayanus (Gilliams). PIRATE PERCH.

Head 3; depth 3. D. III, II to IV, IO; A. II, 6; scales 45 to 6o. Body oblong, elevated at base of dorsal, compressed behind. Head thick, depressed; mouth moderate, lower jaw projecting. Lateral line imperfect or wanting. The position of the anus is peculiar, being always anterior; it 
varies in position with age from just behind the ventrals in the young, to below the preopercle in the adult. Color, dark olive, profusely speckled with dark points, which may form streaks along the rows of scales; 2 blackish bars at base of caudal. Length 5 inches. The Ohio form is the variety isolepis.

The Pirate Perch seems to be a rather rare species in Ohio, and thus far it has been taken only in Lake Erie and the Maumee river system. "Lake Erie," Henshall, I889; Maumee riv'er system, "only two small specimens were taken, one by Prof. Meek in Gordon creek near Cecil, and one by us in warm sluggish water in St. Mary's river at Rockford,' Kirsch, I893.

\section{Sub-Order: PERCESOCES. \\ Family: ATHERINIDE. \\ Genus: LABIDESTHES.}

Labidesthes sicculus Cope. BROOK SILVERSIDES.

Head $4^{1 / 4}$ to $4^{1 / 2}$; depth 6 ; eye large, $3 \frac{1}{2}$. D. IV-I, II; A. I, 23; scales 75. Body very long and slender, compressed. Head long, flattened above; snout long, slender and conic; mouth very large, the jaws produced into a sort of beak. First dorsal very low, inserted well back; caudal forked. Color pale olive green, translucent, dotted above with fine, dark specks; a broad, distinct, silvery lateral band, bounded above by a dark line. Length $31 / 2$ inches.

This peculiar and interesting little fish is widely distributed over the state and is generally common. Quiet pools of streams and shallow waters of lakes on sandy or gravelly bottom are its favorite haunts. Hamilton County, "one specimen from Bloody Run, common in Ross lake," Henshall, i 888 ; Lorain County, "quite common in the lake and in the larger streams below the dams," McCormick, I892; "generally distributed in the waters of the Maumee basin," Kirsch, 1893; Franklin County, generally distributed, abundant, Williamson and Osburn, I897; Huron river at Milan, Sandusky Bay, Wabash river at Celina, Stillwater creek near Dayton, very abundant on sandy bottom in shallow water in Sandusky Bay, R. C. Osburn, I899; Mahoning river, E. B. Williamson, Igoo; Pippin lake, Chippewa lake, Summit lake, Grand river at Painesville, Chagrin river at Willoughby, Ohio river at Bellaire, Licking reservoir, R. C. Osburn, Igoo. 


\section{Sub-Order: RHEGNOPTERI. \\ Group: PERCOIDEA. \\ Family: Centrarchide. \\ Key to Genera.}

A. Dorsal fin scarcely longer than anal.-

Pomoxis.

AA. Dorsal fin much larger than anal.

B. Body comparatively short and deep, the depth usually more than $\frac{a}{5}$ the length.

C. Tongue and pterygoids with teeth; mouth large, maxillary reaching past. middle of eye.

D. Opercle emarginate behind; anal spines 6.-

AMBLOPLITES.

DD. Opercle ending in a black, convex process or flap; anal spines, 3.CHANOBRYTTUS.

cC. Tongue and pterygoids toothless; mouth small, maxillary barely reaching past middle of eye.

E. Supplemental bone of maxillary perfectly distinct.- Apomotrs.

EE. Supplemental bone of maxillary rudimentary or wanting.

F. Lower pharyngeal bones narrow, the teeth usually sharp, not conical.-

LEPOMIS.

FF. Lower pharyngeals broad and concave, especially in the adult, teeth more or less blunt and paved.- Eupomotis.

BB. Body comparatively elongate, depth in adult about $1 / 3$ the length; mouth large.MICROPTERUS.

\section{Genus: Pomoxis.}

\section{Key to Species.}

A. Dorsal spines 6 , occasionally 5 , rarely 7 ; profile strongly sinuate, anal fin plain.annularis.

AA. Dorsal spines 7 , rarely 8 ; profile not strongly sinuate; anal fin reticulate with dark markings.sparoides.

\section{Pomoxis annularis Rafinesque. CRAPPIE; LAKE ERIE BASS ;} CALICO BASS.

Head 3 ; depth $21 / 3$; eye large, 4. D. V or VI, or sometimes VII, I5; A. VI, I8; scales 6-48-I4. Body elongate, much compressed. Head long; the profile from snout to dorsal strongly sinuate; mouth very wide. Fins very high, but lower than in $P$. sparoides. Color, silvery olive, mottled with dark green, the dark marks chiefly on upper part of body and having a tendency to form vertical bars; dorsal and caudal marked with dark green, anal nearly plain. A lighter colored fish than $P$. sparoides. Quite variable. Length 12 inches.

Well distributed over the state in larger streams and lakes, common. Recorded for the state by Dr. Kirtland, who gave it the name Cichla storeria. "It occurs in large numbers in the Ohio river and its tributaries, rarely taken in Lake Erie," Jordan's Report; Muskingum river, Ohio river at Raccoon Island, Henshall, I889; Lorain County, common, McCormick, I892; 
Franklin County, Scioto river, Olentangy river, Big Walnut creek, Big Darby creek, abundant, Williamson and Osburn, I897; Ohio river at Ironton, Huron river at Milan, Wabash river at Celina, North Fork of Licking river at Newark, R. C. Osburn, I899; Ohio river at Bellaire, Chippewa lake, R. C. Osburn, I9oo. It is worthy of note that in Chippewa lake, which drains into the Ohio river system, this species was found exceedingly abundant, but none of the next species, $P$. sparoides, were taken, while in Summit lake, with very similar surroundings, but draining into. Lake Erie, only $P$. sparoides was taken. These lakes are but a short distance apart, the former being near Medina, the latter at Akron.

\section{Pomoxis sparoides (Lacepede). CALICO BASS; Grass BASS ;} LAKE ERIE BASS ; CrapPIE; Bachelor.

Head 3; depth 2. D. VII or VIII, 15; A. VI, I7 or I8; scales 7-44-I2. Body less elongate than in $P$. annularis; the profile less sinuate, the region over the eye not being so much depressed. Fins very high, anal higher than dorsal, its height 4 or 5 times in length of body. Color silvery olive, mottled with olive green or dark, the markings not tending to vertical bars, but to small, irregular groups and covering the whole body. Anal fin heavily marked like the other vertical fins, with dark olive markings; a dusky opercular spot. Length 12 inches.

Not so common as the preceding, but widely distributed, and occurring throughout the state; perhaps not ascending streams as. far as $P$. annularis. It is said to be more common than $P$. annularis in the lake drainage, while in the Ohio Valley, $P$. annularis is the more common. "In the Great Lakes in large numbers. I have seen but few from the Ohio Valley,' Jordan's. Report; Hamilton County, "common in Ross lake near Elmwood," Henshall, I888; Lorain County, Lake Erie and lower parts of Beaver creek and Black river, McCormick, I892; Maumee river at Defiance and Grand Rapids; St. Joseph river at Edgerton, Fish creek at Edgerton, St. Mary's river at St. Mary's and Rockford, Tiffin river at Brunersburg and West Unity, Hoaglin creek near Oakland, Kirsch, I893; Franklin County, Scioto and Olentangy rivers, not common, Williamson and Osburn, I897; Ohio river at Ironton, Wabash river at Celina, R. C. Osburn, I899; Summit lake, Ohio river at Bellaire, R. C. Osburn, I90o. 


\section{Genus: Ambloplites.}

\section{Ambloplites rupestris (Rafinesque). Rock BASS; GOGGLE-EYYE; RED-EYE.}

Head $23 / 4$; depth 2 to $2 \frac{1}{2}$; eye very large, $3 \frac{1}{2}$. D. XI, Io or II; A. VI, IO; scales 5 to 7-40-12. Body oblong, compressed. Head large, profile little depressed above eye; mouth large and oblique, lower jaw projecting. Preopercle serrate near its angle. Color olive green, tinged more or less with brassy yellow, with much dark mottling; each scale with a dark spot producing longitudinal rows; a black opercular spot. Soft dorsal, anal and caudal with dark mottlings. Length $\mathrm{I} 2$ inches.

A widely distributed and abundant species found in all larger streams and lakes. Recorded by Kirtland as common. Abundant, Jordan's Report; “Lake Erie, Ohio river, near Little Sandy river," Henshall, I889; Lorain County, "common in the larger streams, sometimes taken by the pound nets in the lake," McCormick, I 892; "A common fish at nearly all points where investigations were made," Maumee river basin, Kirsch, I893; Franklin County, nearly every stream, common, Williamson and Osburn, I897; Big Jelloway creek, Knox County, not common, Parker, Williamson and Osburn, I898; John's creek at Waterloo, Huron river at Milan, Sandusky Bay, Ashtabula creek, Wabasb river at Celina, Stillwater and Wolf creeks near Dayton, North Fork of Licking river at Newark, R. C. Osburn, I899; Niggermill Run and Mahoning river, E. B. Williamson, I900; Pippin. lake, Cuyahoga river and Breakneck creek at Kent, R. C. Osburn, I900.

\section{Genus: Ch⿻inoromttus.}

Chænobryttus gulosus (Cuvier and Valenciennes). WARMouTH.

Head $2 \frac{1}{5}$ to $2 \frac{2}{3}$; depth 2 to $2 \frac{1}{2}$; eye 4 to $4 \frac{1}{2}$. The general form and dentition of Ambloplites, with the convex opercle, Io dorsal and 3 anal spines of Lepomis. Preopercle entire. Head large, snout about equal to eye; mouth large, maxillary reaching posterior border of eye, teeth on vomer, palatines, pterygoids and tongue. D. X, 9 or IO; A, III, 8 or 9; dorsal spines. low. Color dark olive green, clouded with darker, usually with red or blue, and brassy; a dark spot on each scale; belly yellowish or brassy. Length 8 to Io inches.

Taken by Kirsch in the Maumee basin in Fish creek, at Edgerton, and Tiffin river at Brunersburg, " not common," I 893 . Not recorded for the state by any other collector. 


\section{Genus: Apomotis.}

\section{Apomotis cyanellus (Rafinesque). GREEN SUNFISH; \\ CREEK SUNFISH ; LITTLLE RED-EYE.}

Head 3; depth 21/2. D. X, II; A. III, 9; scales about 7-48-I 7, 8 rows on cheek. Body oblong, rather elongate in young, becoming short and deep in adults. Mouth large, larger than in Lepomis or Eupomotis, maxillary reaching nearly to middle of eye, lower jaw projecting. Gill rakers long and stiff. Lower pharyngeal teeth acute; a patch of teeth on basibranchial between second and third hypobranchials. Color generally greenish, sometimes nearly black; vertical fins marked with blue or green, in adults in spring the lower fins are very dark and all the fins are edged with silvery; dorsal and anal generally with a black spot on the posterior rays. Quite variable. Length 7 inches.

The Green Sunfish is an abundant resident of the streams of Ohio, but is rarely found in the lakes. It ascends the streams farther than any other species of this family, being found even in small brooks and spring runs. Hamilton County, "abundant in Ross lake and Little Miami river,' Henshall, I888; Lorain County, "abundant in the upper part of small streams and in small ponds," McCormick, I892; Maumee river basin, "taken at nearly every point in all the streams that were examined,' Kirsch, I893; Franklin County, abundant in nearly every stream, Williamson and Osburn, I897; Big Jelloway creek, Knox County, not common, Parker, Williamson and Osburn, I898; Ohio river at Ironton, Huron river at Milan, Ashtabula creek, W'abash river at Celina, Stillwater and Wolf creeks near Dayton, North Fork of Licking river at Newark, R. C. Osburn, I899; Mahoning river, E. B. Williamson, I9oo; Breakneck creek near Kent, outlet of Licking reservoir, R. C. Osburn, I9oo. 


\section{Genus: LEPOMIS.}

\section{Key to Species.}

A. Pectoral fins short, obtuse, not reaching beyond front of anal, considerably shorter than head.megalotis.

AA. Pectoral fins more or less pointed, not much if any shorter than head, and reaching to or beyond front of anal.

B. Opercular flap margined with red, sides with many red spots.- humilis.

BB. Opercular flap without red margin or spot; no red spots on sides, a large spot on posterior. rays of dorsal and anal fins at base.- pallidus.

\section{Lepomis megalotis (Rafinesque). LONG-EARED SUNFISH.}

Head (without earflap) 3 in length; depth $I \frac{2}{3}$ to $2 \frac{1}{2}$; eye $3 \frac{1}{2}$ to 4 . D. X, Io to I2; A. III, 8 to IO; scales about $6-38-12$, about 5 .rows on cheek. Body short and deep, compressed; the back very strongly arched in adult, the profile very steep. Mouth small, oblique. Gill rakers very short and soft. Dorsal spines very low, 3 in head. Pectoral $I \frac{1}{3}$ to $I \frac{1}{2}$ in head. Opercular flap in adult very broad and long, with a pale blue or red margin which may be very broad or almost wanting; the flap much smaller in young. Color brilliant blue and orange; above chiefly blue, the belly entirely orange, lips blue; cheeks orange, with bright blue stripes; soft parts of vertical fins with the rays blue and membranes orange. An extremely variable species. Length 8 inches.

An abundant species in the Ohio river system, but not so common in the lake drainage. It occurs both in lakes and streams, but to greater extent in the latter. It does not ascend streams as far as Apomotis cyanellus, however. Given by Kirtland as Pomotis nitida. Hamilton County, " abundant in Ross lake," Henshall, I888; Lorain County, rare, two specimens from Black river, I890, McCormick; Maumee system, "all the larger streams and nearly all the smaller ones," July I7 given as a breeding date, Kirsch, I893; Franklin County, nearly all the streams, apparently the most common sunfish, June I 8 given as a breeding date, Williamson and Osburn, I897; John's creek at Waterloo, Huron river at Milan, Ashtabula creek, Wabash river at Celina, Stillwater and Wolf creeks near Dayton, North Fork of Licking river at Newark, R. C. Osburn, I899; Niggermill Run at Salem, E. B. Williamson, I900; Sandusky Bay, Summit lake, Ohio river at Bellaire, Licking reservoir, R. C. Osburn, I900. 
Lepomis humilis (Girard). RED-SPOTTED SUNFISH.

Head $23 / 4$ to 3 ; depth $2 \frac{1}{4}$ to $2 \frac{1}{2}$; eye large, 3 to $3 \frac{1}{2}$. D. X, Io or II; A. III, 8 or 9 ; scales large, $5-34-$ II, about 5 rows on cheek. Body oblong, profile not very steep. Mucous pores on head very large; opercular flap long, broad and with a very broad, red margin, which entirely surrounds the black. Longest dorsal spine not quite half head, pectoral a little shorter than head. Gill rakers rather long and blunt, well developed. Color, bluish with conspicuous greenish spots posteriorly; sides with many conspicuous round, salmon-red spots; a faint black spot on last rays of dorsal; belly and lower fins red. Length 4 inches.

This small, highly colored sunfish is found in Ohio in the southwestern part only. I know of but one record, as follows: Hamilton Co., "common in Ross lake and Clough creek," Henshall, I 888 .

\section{Lepomis pallidus (Mitchill). BI,UE-GILL; BLUE BREAM ; COPPER-NOSED BREAM; BLUE SUNFISH.}

Head $2 \frac{3}{4}$ to $3 \frac{1}{4}$; depth about 2 ; eye $3 \frac{1}{2}$ to 4 . D. X, II; A. III, Io to I2; scales about 7-45-I2, 5 rows on cheek. Body comparatively short and deep, compressed; the joung slender, adults nearly orbicular, caudal peduncle rather slender. Head rather small, the projecting snout forming an angle above eye. Mouth quite small, the maxillary barely reaching front of eye. Opercular flap very short in young, somewhat larger in adult, without pale edge. Gill rakers of moderate length, rather stiff. Dorsal fin high; pectoral fin long and narrow, longer than head, reaching past front of anal. Color, olive green, sometimes quite dark, sometimes with a silvery or golden luster. Adults in spring with the belly coppery red. Young, silvery with more or less distinct, chain-like bars of darker on the sides. No blue stripes on cheek; a black blotch at base of posterior rays of dorsal and anal. Extremely variable. Length $\mathrm{I} 2$ inches.

The Blue-gill is a very abundant species in the lakes of Ohio. It is quite common and widely distributed in the larger streams, but does not ascend small streams. Hamilton County, "abundant in Little Miami river and Ross lake," Henshall, r888; Lorain County, " not common," McCormick, I892; Maumee river system, "taken in all the streams and at nearly every point examined," Kirsch, I893; Franklin County, Scioto and Olentangy rivers, Big Walnut and Big Darby Creeks, rare, June I 4 given as a breeding date, Williamson and Osburn, I897; Huron river at

(Lepomis machrochirus Rafinesque, has been taken in the head waters of the Ohio in western Pennsylvania, by Cope, and in the Ohio river, by Rafinesque and Jordan, but as I know of no record of its capture within the state. I hesitate to include it in the list, though it doubtless occurs rarely in the Ohio.) 
Milan, Sandusky Bay, Wabash river at Celina, R. C. Osburn, I 899: I have observed the species also at Licking and St. Mary's reservoirs. In both of these and in Sandusky Bay it is very abundant; Pippin lake, Chippewa lake, Summit lake, Ohio river at Bellaire, R. C. Osburn, I900.

\section{Genus: Eupomotis.}

\section{Key to Species.}

A. Cheeks without marked blue or orange spots or lines.

B. Scales large, 34 to 39 in lateral line.-

BB. Scales moderate, 33 in lateral line.

heros.

euryorus.

AA. Cheeks with wavy blue lines, scales about 45 ; lower posterior border of opercular flap always scarlet. gibbosus.

Eupomotis heros (Baird and Girard).

Head $2 \frac{4}{5}$ to 3 ; depth 2 to $2 \frac{2}{5}$; eye $3 \frac{1}{2}$ to $4 \frac{1}{3}$; snout $3 \frac{1}{2}$ to 4 . D. X, II; A. III, II; scales 4-34 to $39-\mathrm{r} 3,4$ rows on cheek. Appearance of Lepomis pallidus. Body robust, moderately elongate, dorsal and ventral outlines about equally curved. Head rather large, a considerable depression in profile above eye; mouth rather large, maxillary reaching past front of eye. Dorsal spines rather high; pectorals reaching beyond middle of anal. Opercular flap smaller than eye, much as in E. gibbosus. Pharyngeal teeth not so blunt as in gibbosus. Color dark greenish above, gradually becoming brassy on belly; opercular spot greenish black, the flap with a broad, bloodred border in male, plain in females. No spot on dorsal or anal. Length about 8 inches.

This is a species of southern distribution, and in Ohio probably occurs only in the southwestern part of the state. It has been recorded, in I888, for the Little Miami river in Hamilton County, by Henshall, under the name Lepomis notatus.

\section{Eupomotis euryorus (McKay).}

Head $3 \frac{33}{4}$; depth $2 \frac{2}{5}$. D. X, II; A. III, IO; scales $6-43^{-14}, 6$ or 7 rows on cheek. Body very robust, compressed, dorsal outline more convex than ventral; profile steep, convex. Mouth oblique, small, maxillary reaching front of eye. Teeth on front of palatines. Lower pharyngeals with the rather long posterior spur turned up, stoutish; the inner angle rounded, somewhat obtuse. Teeth stout, very much blunted, not close set. Gill rakers short and stout, the inner surface roughened. Opercular flap nearly as long as snout, with a very broad, pale membranous margin. Dorsal spines low; ventrals and pectorals short, reaching vent. Color in spirits, mottled olive, yellowish below; top of head blackish; membranes of vertical fins dusky; ventrals dusky, with lighter margins; pectorals pale. Length 8 inches. 
This rare sunfish has been recorded from but two localities in Ohio, both of these to the credit of Mr. McCormick, who says of them: "I took several specimens near Huron, July 6, I89I, and two near Lorain, in September.' Only two other specimens were known at the time Mr. McCormick took these.

\section{Eupomotis gibbosus (Linnaeus). COMMON SUNFISH ; PUMPKin SFED; SunNy.}

Head 3 to $3 \frac{1}{4}$; depth $13 \frac{3}{4}$ to 2 ; eye 4 to $4 \frac{1}{2}$; snout $4 \frac{1}{2}$. D. X, Io to 12 ; A. III, IO or II: scales about $6-44-\mathrm{I} 3,4$ rows on cheek. Body short and deep, compressed, the profile steep, convex. Head rather small; mouth small, maxillary scarcely reaching front of eye. Dorsal spines high, the longest 2 to $2 \frac{1}{2}$ in head, equal to distance from snout to posterior edge of pupil; pectorals long, as long as head. Gill rakers short and soft, weaker than in any other species except Lepomis megalotis. Pharyngeal teeth all bluntly rounded, paved, the bones very broad and somewhat concave. Opercular flap small, the lower posterior part always liright scarlet, a character which distinguishes this species at once in the adult. Color greenish olive, brilliantly marked with blue and orange on the sides; belly orange; lower fins orange, upper blue and orange-spotted; cheeks orange, with wavy blue streaks. One of the most gaudy of our Sunfishes, and quite variable. Length 8 inches.

An abundant species in the ponds and lakes of central and northern Ohio, common in the large streams and in the quiet waters of bayous. Not common in the smaller streams, and said to be rather rare in the southern part of the state. In Sandusky Bay and in Licking reservoir it is the most abundant sunfish. Ross lake, Hamilton County, and Lake Erie, Henshall, I889; Lorain County, "very abundant below the ripples in the larger streams, and in the bayous near the lake. A few taken in the pounds,' Camden lake, McCormick, I 892; Maumee river system, "abundant in all the lakes, common in all the larger streams, except the Auglaize river, less common in the smaller streams,' Kirsch, I893; Franklin County, Scioto and Olentangy rivers, Big Walnut and Big Darby creeks, not common, Williamson and Osburn, I897; Huron river at Milan, Sandusky Bay, St. Mary's reservoir, Wabash river at Celina, North Fork of Licking river at Newark, R. C. Osburn, I899; Pippin lake, Chippewa lake, Summit lake, Licking reservoir, abundant in all these localities, R. C. Osburn, 1900 . 


\section{Genus: Micropteres.}

\section{Key to Species.}

A. Eleven rows of scales above lateral line, about 77 rows on cheek.AA. Seven rows of scales above lateral line, about to rows on cheek.-

dolomieu salmoides.

Micropterus dolomieu Lacepede. SMALL-MOUTHED BLACK Bass.

Head $2 \frac{1}{2}$ to $3 \frac{1}{2}$; depth $2 \frac{3}{4}$ to $3 \frac{1}{2}$; eye 5 to $6 \frac{1}{2}$. D. X, 13 to 15 ; A. III, Io to I2; scales $I I-72$ to $85^{-25}$ (Ohio specimens average about 75 in lateral line). Body rather elongate in young, becoming deeper with age. Mouth large, but smaller than in $M$. salmoides, the maxillary usually not extending back of posterior edge of orbit. This species can always be distinguished at once from $M$. salmoides by the smaller scales, there being II rows of scales above the lateral line, while in salmoides there are but 7 rows. The color is exceedingly variable, giving rise to a number of local names among sportsmen. The usual color is a dark green, with bronze or golden reflections, sometimies almost black on the back; belly lighter. A lateral band never present. Said to reach a length of 2 feet.

Widely distributed over the state and common everywhere in suitable localities. Dr. Jordan aptly says in regard to its habits, " as compared with $M$. salmoides it is a fish of the running waters, having little liking for warm and grassy ponds, bayous or lakes." It is found in nearly all streams, sometimes even ascending small, spring-fed brooks. Recorded by all students of Ohio fishes from Rafinesque and Le Sueur on down, and under a great variety of names. I give the locality records of later investigators. Hamilton County, "common in Little Miami river," Henshall, I888; Lorain County, "common in the larger streams, not so often seen in the lake as the next species," McCormick, I892 ; Maumee river system, "common in all the streams, none from the lakes," Kirsch, I893; Franklin County, generally abundant, Williamson and Osburn, I897 ; Big Jelloway creek system, Knox County, nearly all streams, abundant in some places, Parker, Williamson and Osburn, I898; John's creek at Waterloo, Ice creek at Ironton, Huron river at Milan, Sandusky Bay, Ashtabula creek, Wabash river at Celina, Stillwater and Wolf creeks near Dayton, North Fork of Licking river at Newark, R. C. Osburn, I899; Mahoning river, E. B. Williamson, I90o; Cuyahoga river at Hawkins, Grand river at Painesville, Chagrin river at Willoughby, Wheeling creek at Bridgeport, Ohio river and McMahon creek at Bellaire, Licking reservoir, R. C. Osburn, I9oo. 
Micropterus salmoides (Lacepede). LARGE-MOUTHED BLACK BASS; OSWEGU BASS; GREEN BASS; BAyOU Bass.

Head 3 to $3 \frac{1}{2}$; depth 3 to $3 \frac{1}{4}$; eye 5 to 6 . D. X, I2 or I 3 ; A. III, Io or II; scales 7-65 to 70-18. Body much as in $M$. dolomieu, ovate-fusiform. Mouth very large, maxillary (except in very young) reaching past eye. Always distinguishable from $M$. dolomieu by the larger scales, 7 rows above lateral line. Color variable, usually dark green above, becoming greenish silvery on sides and belly. Young always with a distinct, black lateral band, which becomes fainter with age and disappears entirely at about the fourth year. Length $I \frac{1}{2}$ to $2 \frac{1}{2}$ feet.

This species is found in lakes, bayous and in channels of larger streams. It is a fish of the quiet water. Widely distributed. Like the preceding species it has been the subject of much synonymy. Rafinesque records it under the name Lepomis pallida, for the Ohio, Miami and Hocking rivers. Hamilton County, "common in Ross lake," Henshall, i 888 ; Lorain County, " more common in the lake than in the streams," McCormick, I892 ; Maumee river system, common in all the lakes, also common in the Maumee river and most of its larger tributaries, but none in Auglaize river or its tributaries, Kirsch, 1893 ; Franklin County, Scioto river, Big Walnut creek, Big Darby creek, not common, Williamson and Osburn, I 897 ; Ohio river and Ice creek at Ironton, John's creek at Waterloo, Huron river at Milan, Sandusky Bay, Wabash river at Celina, R. C. Osburn, I899; Pippin lake, Chippewa lake, Summit lake, Grand river at Painesville, Licking reservoir, R. C. Osburn, I9oo. 


\section{Family: PERCIDF.}

\section{Key to Genera.}

A. Pseudobnanchiæ well developed; preopercle serrate; branchiostegals 7 ; no ana! papilla.

B. Canine teeth on jaws and palatines; body elongate; ventral fins well separated.STIZOSTEDION.

BB. Canine teeth none; body oblong, ventral fins near together.- PERCA.

AA. Pseudobranchiæ imperfect or wanting ; preopercle entire or nearly so ; branchiostegals 6 ; anal papilla usually present.

C. Parietal region of skull depressed, not strongly convex in transverse section, -shaped in section.

D. Cranium broad between the eyes, snout conic, projecting pig-like beyond the inferior mouth.PERCINA.

DD. Cranium not broad between the eyes, snout not much proj cting.

E. Body not hyaline nor extremely elongate, its surface almost entirely covered with scales.

F. Premaxillaries not protractile, the skin of the premaxillary continuous in the middle with that of the forehead with no cross groove between.-

HADROPTERUS.

FF. Premaxillaries protractile (in Cotiogaster shumardi a narrow, connecting frenum sometimes crosses from the premaxillary to the forehead),

G. Anal spines 2, both well developed, the first usually the longer.

H. Mid-line of belly naked or covered by caducous shields; gill membranes scarcely conne ted -

COTTOGASTER.

HH. Belly covered with ordinary scales; gill membranes broadly connected.- DrPlesion.

GG. Anal spine single, obscure; anal fin small, much shorter than soft dorsal.- BOLEOSOMA.

EE. Body extremely elongate, hyaline, subterete, the belly mostly naked.

I. Premaxillaries not protractile ; dorsal spines 12 or $\mathrm{I}_{3 .-}-$

CRYSTALlaria.

II. Premaxillaries protractile; dorsal spines 9 to II.-

AMMOCRYPTA.

CC. Parietal region of skull not depressed, more or less strongly convex in crosssection, $\cap$-shaped; premaxillaries never protractile; belly covered with ordinary scales.

J. Lateral line straight; body rather robust.-

Етнеоsтомa.

JJ. Lateral line with a slight arch running high anteriorly ; body slender.BOLEICHTHYS. 


\section{Genus: Stizostedion.}

Key to Species.

A. Pyloric coeca 3 ; soft dorsal with about 20 rays; a biack spot on last dorsal spines.vitreum.

AA. Pyloric coeca 4 to 7 ; soft dorsal with about 17 rays; no black spot on posterior dorsa spines, a black blotch at base of pectoral : second dorsal with rows of dark spots.canadense.

Stizostedion vitreum (Mitchill). WALL-EYed PIKE; PIKE PERCH; Yellow Pike; Blue Pike; Jack Salmon.

Head $3^{2} \frac{3}{3}$; depth about $4 \frac{1}{2}$; eye $4^{1 / 2}$ to 5 . D. XII to XVI, I9 to 21 ; A. II, I 2 to I4; scales IO-I Io to I32-25; lateral line incomplete. Body slender, becoming compressed with age. Cheeks and upper surface of head nearly naked. Dorsal spines high, more than one-half the length of head; dorsal fins well separated; soft dorsal nearly as long as the spinous. Pyloric coeca, 3. Color, dark olive, finely mottled with brassy; sides of head more or less vermiculated; belly and lower fins pinkish; spinous dorsal with a large, jet black spot on posterior 2 or 3 membranes. Length about 3 feet.

Common in Ohio river and Lake Erie, and sometimes ascending their larger tributaries. Kirtland reported it from Lake Erie and the Maumee and Ohio rivers under the name Lucio-perca americana. Hamilton County, " abundant in the Ohio river," Henshall, I888; Lorain County, "very common in the lake, entering the streams occasionally,'” McCormick, I892 ; Maumee river at Grand Rapids and Toledo, and Lake Erie around the mouth of the Maumee in large numbers, Kirsch, I893; Huron river at Milan, Sandusky Bay, R. C. Osburn, I899.

Stizostedion canadense griseum (De Kay). SAUgER ; SAND PIKE;

Gray Pike; Pickering.

Head $3 \frac{1}{2}$; depth varying with age, $4 \frac{1}{2}$ to 6 ; eye 5 . D. XI to XV-I, I 7 to I9; A. II, II or I2; scales 9 -IOO to I25-27; lateral line incomplete. Body more terete than in $S$. vitreum. Head depressed, pointed; opercular spines fewer than in the typical $S$. canadense, and the head less completely scaled. Color, olive gray, sides brassy or orange, with dark mottlings; spinous dorsal with 2 or 3 rows of irregular, dark spots, no large, black spot ori posterior rays. A more translucent fish than $S$. vitreum. Pyloric coeca 4 to 7 . Length about 18 inches.

Distributed about as the preceding species. Common both in the lake and Ohio river. " Abundant in the Great Lakes, plentiful in Ohio river," Jordan's Report ; Hamilton County, "common in the Ohio river,' Henshall, I888; Lorain County, "common in the lake, entering streams oftener than S. vitreum," 
McCormick, I892; Maumee river at Grand Rapids, Waterville and Toledo, Blanchard river at Ottawa, west end of Lake Erie, Kirsch, I893. I have seen many dead ones on the lake beach at Sandusky.

\section{Genus: PERCA.}

\section{Perca flavescens (Mitchill). YELLOW PERCH; RINGED PERCH.}

Head $3 \frac{1}{4}$; depth $3 \frac{1}{4}$. D. XIII to XV-II, I3 to I5; A. II, 7 or 8 ; scales 7-74 to 88-17; lateral line incomplete. Body slender in young, becoming stouter with age; adults have the back considerably arched, the profile convex from dorsal to occiput, thence concave forward to the projecting snout. Cheeks closely scaled; well developed striae on operculars and rugosities on top of head. Color, dark olivaceous above, sides golden yellow, with 6 or 8 broad, dark vertical bars; belly pale, lower fins red or orange. Length I foot.

A fish of the quiet waters, found abundant in the reservoirs, ponds, bayous and lakes of central and northern Ohio, but not recorded for the southern part of the state. Kirtland recorded it (Bodianus flavescens) as abundant in Lake Erie and the small lakes of northern Ohio. "St. Mary's reservoir and Lake Erie," Henshall, I 889 ; Lorain County, " common in the lake and lower portions of the rivers," McCormick, I892; Maumee river at Grand Rapids, Waterville and Toledo, St. Mary's riv.r at St. Marys, Tiffin river at Brunersburg, west end of Lake Erie, Kirsch, I893; Huron river at Milan, Sandusky Bay, Wabash river at Celina, St. Mary's reservoir, R. C. Osburn, I899; Summit lake and Licking reservoir, R. C. Osburn, I900. It is very abundant in Sandusky Bay and common in Licking reservoir. I have also seen the species from the Ohio canal at Newark.

\section{Genus: PERCina.}

Percina caprodes (Rafinesque). LOG PERCH; HOGFISH; HOG MOLLY; STONE ROLLER.

Head 4 to $43 / 4$; depth 5 to $61 / 2$; eye 4 . D. about XV-I5; A. II, II, Body elongate, slender. Head long and pointed, depressed and sloping above; snout "pig-like," projecting beyond the inferior mouth; eyes widely separated. Color, light yellowish or yellowish green, with about I5 vertical, dark bars extending down on sides below lateral line and alternate with the same number of shorter bars. Length 8 inches. 
This largest of Ohio darters is widely distributed over the state and generally common. It is found in the quiet waters of streams of all sizes (but more commonly in the larger ones), and in lakes, on gravelly or sandy bottom. Given by Rafinesque for the Ohio and Miami. Kirtland reported it "common," and Jordan, "generally abundant." Hamilton County, "common in Little Miami river and Ross lake,' Henshall, I888; Lorain County, "not very common, taken both in rivers and the lake, abundant in Sandusky Bay and Put-in-Bay, and it formed the bulk of the fishes that I saw among the terns' nests on Rattle Snake Island,' McCormick, I892 ; Maumee river system, rather common, nearly all streams, Kirsch, I893; Franklin County, generally distributed, common, but nowhere abundant, Williamson and Osburn, I897; Big Jelloway creek, Knox County, "ccommon," Parker, Williamson and Osburn, I898 ; Ohio river at Ironton, Huron river at Milan, Ashtabula creek, Wabash river at Celina, Stillwater creek at Dayton, North Fork of Licking river at Newark, R. C. Osburn, I899; Lake Erie at Sandusky, Cuyahoga river at Kent and Hawkins, Breakneck creek at Kent, Chippewa lake, Summit lake, Grand river at Painesville, Ohio river at Bellaire, Licking reservoir, R. C. Osburn, I900.

To the northward this species is represented by the following variety :

\section{Percina caprodes zebra (Agassiz). MANITOU DARTER.}

This variety is found in the northern part of the state, with the typical caprodes. It is known chiefly by the lack of scales on the nuchal region, the rather more slender form, and the shorter vertical bars. It intergrades with the typical caprodes.

The Manitou Darter has been recorded for the state by McCormick in Lorain County, I892, as "occuring with the typical form in proportion of about I to 3, some specimens showing intermediate stages;' Lake Erie at Sandusky, Cuyahoga river at Hawkins, and Grand river at Painesville, R. C. Osburn, I9oo. 


\section{Genus: Hadropterus.}

\section{Key to Species.}

A. Mid-line of belly with a series of enlarged caducous plates, which fall off at certain intervals, leaving a naked strip from breast to vent; preopercle strictly entire, not serrated.

B. L,ower jaw as long as upper, snout very narrow and pointed,-phoxocephalus.

BB. Lower jaw shorter than upper, included; head moderate, not long and pointed

C. Cheeks with very small scales; dorsal spines I3 to I5.- aspro.

CC. Cheeks naked; dorsal spines io to r2.- evides.

AA. Enlarged plates of mid-line of belly persistent at least posteriorly ; preopercle finely serrated.scierus.

\section{Hadropterus phoxocephalus (Nelson).}

Head $3 \frac{2}{3}$ to 4 ; depth $5 \frac{1}{2}$ to 6 ; eye $4 \frac{1}{2}$. D. XI or XII-I2 to I4; A. II, 8 or 9; scales $12-8$ o to $85-16$; lateral line incomplete. Body slender. Head very long and pointed; mouth terminal, large; jaws sub-equal; snout very long, acuminate. Cheeks, opercles and neck with small scales, breast naked; caducous shields of midline of belly small. Gill membranes somewhat connected. Color, brownish olive, much vermiculated; a row of about $\mathrm{r} 4 \mathrm{dark}$, quadrate spots, sometimes confluent, along lateral line. Length 6 inches.

Recorded from three widely separated localities, which would indicate a general distribution, yet it seems to be quite rare except in the southwestern part of the state, where Henshall, I888, reports it as common in Little Miami river. One specimen was taken near Lorain, by McCormick, I 892 ; and Mr. E. B. Williamson and the writer took a single specimen in Big Walnut creek near Lockbourne, Franklin County.

\section{Hadropterus aspro (Cope and Jordan). BLACK-SIDED DARTER.}

Head 4 ; depth 5 to 6 ; eye 4 . D. XIII to XV-II to I3; A. II, 8 to Io; scales $9-65$ to $80-17$, lateral line incomplete. Body rather elongate, subterete, compressed behind. Head moderately elongate; snout blunt; mouth sub-inferior, lower jaw included; gill membranes slightly or not at all connected. Opercle with rather large scales; cheek with very small, imbedded scales; breast naked; caducous scales of mid-ventral line rather large. Color light yellowish or greenish yellow, tessellated above with dark olive or blackish; white below; about 8 large, dark blotches along lateral line, these often confluent; fins barred. Length about 4 inches.

A common species throughout the state. Found in clear streams on gravelly bottom. Hamilton County, "common in East Mill creek," Henshall, I888; Lorain County, " nowhere common, but found in most streams and the lake," McCormick, I892 ; Maumee river system, "abundantly distributed in all the 
streams examined,' Kirsch, I893 ; Franklin County, a common darter of general distribution, Williamson and Osburn, I897; Big Jelloway creek, Knox County, “'common,' Parker, Williamson and Osburn, I898; John's creek at Waterloo, Huron river at Milan, Ashtabula creek, Wabash river at Celina, Stillwater creek at Dayton, North Fork of Licking river at Newark, R. C. Osburn, I899; Ohio river at Bellaire, outlet of Licking reservoir, R. C. Osburn, I900.

\section{Hadropterus evides (Jordan and Copeland).}

Head $4^{1 / 3}$; depth $5 \frac{1}{3}$; eye $3^{1 / 2}$, large and high in head. D. XI-IO; A. II, 8 or 9 ; scales $9-52$ to $67-9$ to II. Body moderate, somewhat compressed. Head heavy, the profile rather convex. Mouth moderate, lower jaw included. Cheeks, nape and throat naked; opercles with rather large caducous scales; ventral shields but little enlarged. Fins large, pectorals long. Coloration extremely brilliant in breeding males, females and young plainer. General color above, dark olivaceous, tessellated with darker; back and sides with about 7 broad, transverse bars; fins marked with orange, black, bronze, yellow and blue-black. "One of the most brilliant of all fishes." Length 2 or 3 inches.

Rare in Ohio, its distribution being more westerly. The species has, however, been taken in the Ohio river at Raccoon Island, by Dr. Henshall, I889, and by Kirsch, in the Maumee river at Grand Rapids.

\section{Hadropterus scierus Swain.}

Head 4 to $4 \frac{4}{5}$; depth 5 to 6 ; eye 4 to $4 \frac{1}{2}$. D. XIII-I3 or I4; A. II, 9; scales 7-68 to 70-I7. Body robust. Head rather short, snout bluntish; mouth small, lower jaw included; preopercle more or less distinctly serrate. Gill membranes broadly connected. Opercle with large scales, those on cheek slightly smaller. Throat naked, breast nearly so. Ventral shields but little enlarged and not caducous except anteriorly. Color yellowish olive, everywhere vaguely blotched with black; top of head, dorsal, anal and ventral fins black in male, paler in female; scales everywhere finely punctulate with brown; sides with a few larger, black specks. Length 5 inches.

Rare. Like the preceding species, its distribution is westerly. I know of but one record for the state, that by Henshall, "Ohio river, near Little Sandy river, I889."

Mr. McCormick has recorded (I892) this species from Vermillion river, two specimens. $H$. peltatus, as now understood, occurs from southeastern Pennsylvania sonthward along the coast, and is not known west of the Alleghanies. so I am inclined to think there must be some error in the above record. Under this belief $I$ omit the species from the Ohio list. 


\section{Genus: CotTtogaster.}

Key to Species.

A. Mid-line of belly with a series of enlarged caducous scales or plates. - copelandi

AA. Mid-line of belly naked anteriorly, covered with ordinary scales posteriorly.-

Cottogaster copelandi (Jordan).

shumardi.

Head $3 \frac{3}{4}$ to $4 \frac{1}{4}$; depth $5^{1 / 2}$ to $6 \frac{1}{2}$; eye about $3 \frac{1}{2}$. D. X to XII-IO to I 2; A. II, 8 or 9 ; scales $6-44$ to $56-8$. Body rather slender. Head rather large and long, much resembling that of Boleosoma. Mouth small, horizontal, sub-inferior, cheeks naked; opercles and neck with a few scales, throat naked; ventral plates well developed. Pectoral fin as long as head. Color, brownish olive, tessellated above; a series of small, oblong, dark blotches along lateral line, sometimes indistinct. Vertical fins with dusky specks; a black spot on anterior rays of spinous dorsal. Length $2 \frac{1}{2}$ or 3 inches.

Widely distributed over the state, but apparently very rare everywhere. Muskingum river, and Ohio river at Raccoon Island, I889, and Lake Erie at Put-in-Bay, Henshall; Lorain County, "Vermillion river, but one specimen taken," McCormick, I892 ; Maumee river at Toledo, two specimens, Kirsch, 1893 ; in Huron river at Milan, in 1897 , two specimens were taken by Prof. D. S. Kellicott, Mr. E. B. Williamson and the writer.

\section{Cottogaster shumardi (Girard).}

Head $3 \frac{2}{5}$ to 4 ; depth 5 to $5 \frac{1}{2}$; eye $3 \frac{1}{2}$. D. IX to XI-I3 to I5; A. II, IO to I2; scales 6-48 to 6O-II. Body stout, heavy forward, compressed behind. Head broad and thick. Mouth large and broad, lower jaw the shorter. Premaxillaries usually protractile, but a narrow frenum sometimes present. Cheeks, opercles and neck usually scaly; chest naked; belly naked anteriorly, scaled for a short distance before vent. Color dark, densely but vaguely spotted with darker; sides with 8 or 10 obscure blotches; a large, black spot at base of spinous dorsal behind, and a small one in front. Length 3 inches.

Not common, but occuring in both the Lake Erie and Ohio river drainage. Found on sandy bottom in rivers, not found in small streams. Recorded by Henshall for the Muskingum river and for the Ohio river near Parkersburg, I889; recorded for Vermillion river as Etheostoma wrighti, by McCormick, I892 ; in I 899 the writer took a half dozen specimens in the Ohio river at Ironton, and in August, I900, the species was again taken at Bellaire. 


\section{Genus: Diplesion.}

Diplesion blennioides (Rafinesque). GREEN-SIDED DARTER.

Head about $4 \frac{1}{2}$; depth $4 \frac{3}{4}$ to 6 . D. XII to XIV-I2 to I5; A. II, 8 or 9 ; scales $6-58$ to 78 -I4. Body elongate, subterete. Head short, profile very convex, snout very blunt, cheeks tumid; eyes large, $3 \frac{1}{2}$, high up and close together; mouth small, inferior; gill membranes broadly connected. Cheeks with fine scales, opercles with large ones, breast naked Color dark olive green, tessellated above; sides with 7 or $8 \mathrm{Y}$-shaped, dark bars, these sometimes confluent to form a dark zigzag band. In highly colored males a number of broad, bright green bands almost encircle the body. Females and young may be quite dull, but the pattern of the dark marks on the side is characteristic. Length 3 to 5 inches.

The Green-sided Darter is an abundant resident of the clear, rapid streams of the state, found especially on stony ripples. Rafinesque records it from the Ohio and Muskingum. Kirtland mentions its occurrence in the state, and Jordan gives it as " abundant." Hamilton County, " abundant in East Mill creek and Little Miami river," Henshall, I888; "Vermillion river; scarce, not uncommon in Sandusky Bay,' McCormick, I892 ; Maumee river system, taken in all the larg 2 streams (except St. Mary's river) and nearly all the smaller ones, Kirsch, I893; Franklin County, abundant, and of general distribution, Williamson and Osburn, I897; Big Jelloway creek system, common on ripples, Parksr, Williamson and Osburn, r898; John's creek at Waterloo, Huron river at Milan, Ashtabula creek, Wabash river at Celina, Stillwater creek at Dayton, North Fork of Licking river at Newark, R. C. Osburn, I899; Mahoning river, E. B. Williamson, I900 ; Cuyahoga river at Hawkins, Breakneck creek at Kent, Grand river at Painesville, Chagrin river at Willoughby, Wheeling creek at Bridgeport, Ohio river and McMahon creek at Bellaire, R. C. Osburn, I9oo.

\section{Genus: Bolemosoma.}

Boleosoma nigrum (Rafinesque). JoHNNy DARTER.

Head about 4 ; depth 5 to 6 ; eye $3 \frac{1}{2}$ to 4 . D. IX-II to I4; A. I, 7 to 9 ; scales 5-44 to 55-9. Body fusiform, slender. Head moderate, snout somewhat bluntly decurved; mouth small, lower jaw included. Cheeks and breast usually naked; opercles scaly. Anal spine short and weak; fins all high. 
Color usually pale olivaceous, much tessellated above; sirles with numerous small W-shaped, dark blotches. Males in breeding season heavily pigmented, especially anteriorly, with blue-black. A black line forward and downward from eye. Fins barred. Length 2 to $2 \frac{1}{2}$ inches.

The little Johnny Darter is found all orer Ohio, and is usually quite abundant. It inhabits lakes and rivers on sandy bottom, the clear creeks of Ohio are favorite abiding places, and every small brook and spring run large enough to contain any fish at all will be found to have its quota of " Johnnies." Hamilton County, "common in Little Miami river," Henshall, 1888 ; Lorain County, "very common everywhere, one of the few species that may be depended upon when the seine is drawn," McCormick, I892; Maumee river system, common every where, Kirsch, I893: Franklin County, taken in every stream, abundant, April 3 rd given as a breeding date, Williamson and Osburn, 1897; Big Jelloway creek system, abundant in every stream, Parker, Williamson and Osburn, 1898; John's creek at Waterloo, Huron river at Milan, Sandusky Bay, Ashtabula creek, Wabash river at Celina, Stillwater and Wolf creeks at Dayton, North Fork of Licking river at Newark, R. C. Osburn, I899; Niggermill Run and Mahoning river, E. B. Williamson, I9oo; Pippin lake, Chippewa lake, Summit lake, Cuyahoga river at Kent and Hawkins, Breakneck creek at Kent, Grand rirer at Painesville, Chagrin river at Willoughby, Wheeling creek at Bridgeport, Ohio river and Mc.lahon creek at Bellaire, Licking reservoir, R. C. Osburn, I900.

\section{Genus: Crystallaria.}

\section{Crystallaria asprella (Jordan)}

Head $4 \frac{1}{5}$ to $4 \frac{1}{2}$; depth 7 to 8 . D. XII to XIV-I3 to I5; A. I, I2 to I4; scales 7 to I0-98 to I00-IO. Body long and slender. Head long and slender; eye large; mouth not large, subterminal; premaxillaries not protractile; opercular spine well dereloped. Cheeks and opercles with pectinate scales: throat and belly naked, space between ventrals scaled. Color translucent olive, pellucid in life; with 3 or 4 more or less distinct, dark cross bands on back and sides; a dark lateral band made up of about Io more or less confluent blotches. Length 5 or 6 inches. 
Apparently a very rare species in Ohio, and confined to larger streams. Recorded by Henshall for the Muskingum river, I889; and one specimen was taken on sandy bottom in the Ohio river at Ironton, May 3I, I899, by the writer.

\section{Genus: Ammocrypta.}

\section{Ammocrypta pellucida (Baird). SAND DARTER.}

Head 4 to $4 \frac{3}{4}$; depth 7 to $8 \frac{1}{2}$. D. X-IO; A. I, 8 to IO; scales in lateral line about 75 , about 6 rows above lateral line. Body very long, terete, quite pellucid in life. Head stout; eyes large, high up, interorbital space narrow. Cheeks, opercles, and temporal region with embedded scales; belly and sides below lateral line entirely naked; much of dorsum in front and on either side of dorsal fin naked or thinly scaled. Translucent, sometimes tinged with olivaceous; scales with narrow, dark edging; about I2 or I5 black blotches along the sides; a gilt lateral band. Length 3 inches.

The Sand Darter is well distributed over the state and is common locally in larger streams on sandy bottoms. Taken also in the lake. Hamilton County, common in Little Miami river, Henshall, I 888 ; Lorain County, Lake Erie and the larger streams, not common, McCormick, I892 ; " common everywhere on sandy bottom in the Maumee river, and in the lower courses of the larger tributaries,' Kirsch, I893 ; Franklin County, Olentangy river, Big Walnut and Little Walnut, Big Darby and Black Lick creeks, not common, June 28 given as a breeding date, Williamson and Osburn, I897; Huron river at Milan, Wabash river at Celina, Stillwater creek near Dayton, R. C. Osburn, I899; Grand river at Painesville, Ohio river at Bellaire, R. C. Osburn, I9oo. 


\section{Genus: Eiтнеоттома.}

\section{Key to Species.}

A. Lateral line complete. (A few tubes rare!y wanting.)

B. Gill membranes broadly convected across the isthmus.

C. Anal fin nearly as large as soft dorsal; spinous dorsal with about $\mathrm{I}_{3}$ spines.-

variatum.

CC. Anal fin much smaller than soft dorsal; spinous dorsal with Io or II spines -

zonale.

BB. Gill membranes scarcely connected across the isthmus.

D. Head short, the muzzle abruptly decurved, mouth somewhat inferior, lower jaw included.-

camurum.

DD. Head rather long and pointed, snout not decurved, mouth terminal, jaws subequal.-

maculatum.

AA. Lateral line more or less incomplete.

E. Humeral region without differentiated black, scale-like process,-coeruleum.

EE. Humeral region with distiuct, black process or scale.

F. Gill membranes scarcely connected ; lower jaw not projecting.-

tippecanoe.

FF. Gill membranes connected; lower jaw strongly projecting.-flabellare.

\section{Etheostoma variatum Kirtland.}

Head $3 \frac{1}{2}$ to 4 or more; depth $4^{\frac{4}{5}}$ to $5 \frac{1}{2}$; eye $3 \frac{1}{2}$ to 4 . D. XII-I3 (XII to XIV-II to I3); A. II, 7 to Io; scales $8-5$ I to $63-12$. Body moderately elongate, not much compressed, the back somewhat arched. Head short and thick; snout short and blunt, decurved, parietal region broad and depressed, resembling Hadropterus in this respect; profile above eyes strongly decurved; mouth small, lips thick, lower jaw included; premaxillary not protractile; gill membranes united. Head naked except I to 3 scales on opercle above; breast loosely scaled. Fins all very large, pectorals reaching beyond tips of ventrals. General color above, dark greenish olive, becom_ ing barred vertically on the sides posteriorly, about four black blotches across the back. Females and young similarly marked, but paler. The following color description taken from the living specimen is typical of breeding males: Color, dark olive, with about 8 greenish cross-bars on posterior part of body; interspaces pale, each with 2 bright carmine spots; back crossed by 4 black bars; sides of belly bright orange; middle of belly pale; first dorsal dark brown at base, then a pale space, above this a wide, dark bar, then another pale space, bordered with bright orange; second dorsal and caudal flecked with carmine; anal greenish, bordered with pale orange; ventrals greenish black with a little orange at the margin; pectorals tinged with orange and green, the rays with carmine spots. Length $3 \frac{1}{2}$ inches.

This elegant darter was described by Dr. Kirtland from the Mahoning river in 1838 , and was not taken again in the state for fifty years, until, in 1888 , Henshall recorded it for the Little 
Miami river, near Red Bank, as " not rare." In April, I897, Mr. J. B. Parker found it common on swift ripples in Big Jelloway creek, Knox County, and in May; I898, Messrs. Parker, Williamson and the writer, seining the Big Jelloway creek system, found this to be " the most abundant darter, especially frequenting swift ripples." In Franklin County, in the summer of I897, the species was taken by Mr. E. B. Williamson and the writer on swift ripples in Big Walnut creek, Little Walnut creek, and Black Lick, but nowhere common. In I 899 the writer took the species in North Fork of Licking river near Newark; and in I900, in the Ohio river at Bellaire.

\section{Etheostoma zonale (Cope).}

Head 4 to 5 ; depth 4 to 6 ; eye $3 \frac{1}{2}$ to 4 . D. X or XI-Io to I2; A. II, 6 to 8 ; scales about 6-5c-9. Body rather slender, somewhat compressed. Head small and short; mouth small, subinferior; snout blunt, profile rapidly descending; gill membranes broadly connected. Cheeks, opercles and neck usually scaled, breast usually naked. Color clear olive green above, with 8 or ro greenish blue vertical bands which encircle the body posteriorly; below paler, with a brassy tinge; breast greenish black. First dorsal black at base, then a wide orange bar margined with black anteriorly, with greenish posteriorly; second dorsal orange at base, dark above; caudal and pectorals plain, tinged with green; anal and ventrals green, black at base. Young and females dull and speckled, the vertical bars indistinct and the fins speckled. Length 2 or 3 inches.

This species has been taken in a number of localities of the state, indicating a pretty general distribution. It is locally common, but is only taken on swift ripples. Hamilton County, " common in East Mill creek and Little Miami river,' Henshall, I888; Franklin County, Scioto river, Olentangy river, Big Walnut creek, Little Walnut creek, Alum creek, Black Lick, common where found, Williamson and Osburn, I897 ; Big Jelloway creek system, Knox County, "common on swift ripples," Parker, Williamson and Osburn, I898; Huron river at Milan, Stillwater and Wolf creeks near Dayton, North Fork of Licking river at Newark, R. C. Osburn, I899; Ohio river at Bellaire, R. C. Osburn, I900.

Etheostoma camurum (Cope). BLUE-BREASTED DARTER.

Head $3 \frac{1}{2}$ to 4 ; depth 4 to $4 \frac{1}{2}$. D. XI-I2 or I3; A. II, 8 ; scales $7-50$ to $5^{8-8}$. Body stout, rather compressed. Head short; snout blunt, profile 
rapidly descending; lips thick, lower jaw included. Caudal peduncle deep. Color, dark olivaceous, sometimes nearly black above, somewhat barred on the sides; a dark longitudinal line on cach row of scales; sides irregularly flecked with crimson dots; belly pale; throat and breast deep dark blue. Fins marked with brown, green, black, yellow and crimson. Females less distinctly marked. Length $2 \frac{1}{2}$ inches.

The Blue-breasted Darter is rather rare in Ohio, although it has been taken at a number of widely separated localities, which would indicate a general distribution. It is found in company with $E$. zonale, on swift, stony ripples, but is much less frequent in occurrence. Jordan mentions it for the Mahoning river; " Muskingum river," Henshall, I889; Franklin County, Scioto river, Olentangy river, Big Walnut creek, not common, Williamson and Osburn, I898; Huron river at Milan, Stillwater creek at Dayton, North Fork of Licking river at Newark, R. C. Osburn, I899.

\section{Etheostoma maculatum Kirtland.}

Head $3 \frac{3}{4}$ to 4 ; depth $42 / 3$ to $5 \frac{1}{4}$. D. XII-I2 or I3; A. II, 8 or 9 ; scales 9-56 to 63-I4. Body elongate, caudal peduncle very deep. Head acuminate, the front descending very gradually, the mandible rising as gradually to its extremity; jaws subequal. Lateral line complete; cheeks naked; opercles scaled; gill membranes not connected. Color, above black, shading to dark olive below; throat turquoise blue; sides and dorsum marked with small, circular spots of bright crimson. First dorsal uncolored, with a black spot at its base in front and a dark shade through the middle; second dorsal blood red; caudal with two large, crimson spots confluent on the mid-line of the tail at its base. Female dull, the fins dark barred and not crimson. Length $2 \frac{1}{2}$ inches-

Very rare. The species was described in 1838 from specimens taken in the Mahoning river by Dr. Kirtland. I know of but one subsequent record of its capture within the state. Mr. E. B. Williamson and the writer took a single specimen, a female with ripe eggs, from a swift ripple in Big Walnut creek, near Lockbourne, Franklin County, on June 26, 1897.

\section{Etheostoma cœruleum Storer. RAINBOW DARTER ; BLUE DARTER ; SOLDIER FISH.}

Head $3 \frac{1}{2}$ or more; depth $4 \frac{1}{4}$; eye 4 to $4 \frac{1}{2}$. D. IX to XII-I2 to I4; A. II, 7 or 8; scales $5-37$ to 50 -10. Body robust, rather deep and compressed. Head large, compressed. Mouth moderate, terminal, oblique, the lower jaw somewhat included; gill membranes not united. Cheeks naked 
or nearly so, opercles scaled, neck and breast usually naked. Color, olivaceous, tessellated above; sides with a varying number (about 12j of vertical, indigo-blue bars, separated by orange interspaces; throat, breast and sides of belly orange; cheeks blue-green; first dorsal crimson at base, above this an orange bar, margined with blue; other vertical fins chiefly orange, tipped with blue. Females much plainer, with very little blue or red. Length $2 \frac{1}{2}$ inches.

This elegant little fish is widely distributed over the state; and is generally abundant. It is most common in the smaller streams, and is always found in running water, usually on ripples, and does not occur in lakes. Kirtland reported it in I854 from near Cleveland, under the name Poecilosoma erythrogastrum. Jordan gives it as "the most abundant member of the family." Hamilton County, " very common in East Mill creek, ' Henshall, I888 ; Lorain County; "one of the most common darters," McCormick, I892; Maumee river system, "not taken in the Maumee, St. Mary's and St. Joseph rivers, common in all the other larger streams and nearly all the small ones, ' Kirsch, I893 ; Franklin County, abundant, of general distribution, Williamson and Osburn, r 897 ; Big Jelloway creek, "very common," Parker, Williamson and Osburn, I898; John's creek at Ironton, Huron river at Milan, Ashtabula creek. Wabash river at Celina, Stillwater and Wolf creeks at Dayton, North Fork of Licking river at Newark, R. C. Osburn, I 899 ; Mahoning river, E. B. Williamson, I900 ; Cuyahoga river, at Hawkins, Grand river at Painesville, Chagrin river at Willoughby, Wheeling creek at Bridgeport, McMahon creek at Bellaire, R. C. Osburn, I900.

The following variety of this species is also taken in Ohio:

\section{Etheostoma cœruleum spectabile (Agassiz).}

It is known from the typical species by the "faded out" appearance of the ground color of the back, and by the arrangement of the olivaceous into distinct longitudinal lines. It is also rather more slender than the typical coruleum, into which, both in color and in measurement it insensibly grades.

This variety is found in brooks and smaller streams, replacing to some extent the typical form in central and western Ohio. Specimens from Ohio streams show many intermediate stages. Recorded by Kirsch from Sugar creek, near Lima; Franklin County, taken only iu the small streams, "grading insensibly into 
the typical species,' Williamson and Osburn, I897; headwaters of Wabash river at Celina, Wolf creek near Dayton, brooks tributary to North Fork of Licking river near Newark, R. C. Osburn, I 899 ; Breakneck creek at Kent, tributaries of Grand river at Painesville, R. C. Osburn, I900.

Etheostoma tippecanoe Jordan and Evermann.

Head $3 \frac{1}{2}$ to $4 \frac{1}{4}$; depth $4 \frac{1}{4}$ to $4 \frac{3}{4}$; eye small, $4^{1 / 2}$ in head. D. XII-I 2 ; A. II, 7 ; scales 5 or $6-46$ to $50-8$; lateral line straight, developed on only about 30 scales. Body compressed, caudal peduncle deep. Head rather small, little compressed; mouth large, terminal, oblique, the lower jaw somewhat included; gill membranes scarcely connected. A small, well defined, black humeral scale. Cheeks, throat and breast naked; opercles scaled. Color in life, dark olive green, strongly tinged with yellow, especially posteriorly, passing into greenish yellow on belly; about 14 narrow, well defined, greenish black vertical bands encircling the body posteriorly; breast deep blue-black, the color extending forward on the throat and backward on the ventral fins; dorsal and anal fins golden yellow, pigmented with blue-black; pectorals plain golden yellow; ventrals golden yellow, blue-black at base. Female paler, no high colors, dark markings less distinct. Length $I \frac{1}{2}$ inches.

In Ohio this exceedingly rare darter has been taken only in Franklin County. Four specimen; were taken by Mr. E. B. Williamson and the writer, one in the Olentangy river at Columbus, in September, I896, the other three in Big Walnut creek near Lockbourne, on June 26, I897. The species was taken in very swift ripples.

\section{Etheostoma flabellare Rafinesque. FAN-TAILED DARTER.}

Head $3 \frac{1}{2}$ to 4 ; depth $4 \frac{1}{2}$ to 6 ; eye 4 to 5 . D. VIII-I2 to I 4 ; A. II, 7 to 9; scales about 9-50-14. Body slender, compressed. Head long and pointed; snout not decurved, mouth very oblique, lower jaw projecting; gill membranes well connected. Fins all low, the first dorsal notably so, and, in the male, the spines tipped with fleshy knobs; caudal large, rounded. Head entirely naked; a narrow, bare strip along base of spinous dorsal. Color very dark olivaceous, forming vertical bars on sides; each scale with a dark center; dark humeral spot conspicuous; dorsal and caudal fins barred with black. Some Ohio specimens approach the variety lineolatum, characterized by distinct longitudinal lines along the rows of scales. Length $2 \frac{1}{2}$ inches.

A common species in the clear, rapid str-ams of the state, found especially on ripples. Hamilton County, "common in East Mill creek," Henshall, I888; Lorain County, " rare, 
Vermillion river,' McCormick, I892; Maumee river system, St. Joseph river at Edgerton, Tiffin river at Brunersburg, Sugar creek at Lima, Beaver creek at Grand Rapids, Kirsch, I893 ; Franklin County, nearly every stream, abundant, Williamson and Osburn, I897 ; Big Jelloway creek, Knox County, "'a very common species,'” Parker, Williamson and Osburn, r 898; John's creek at Waterloo, Huron river at Milan, Ashtabula creek, Wabash river at Celina, Stillwater and Wolf creeks near Dayton, North Fork of Licking river at Newark, R. C. Osburn, I899; Niggermill Run at Salem, E. B. Williamson, I90o ; Lake Pippin, Cuyahoga river at Kent, Wheeling creek at Bridgeport, Ohio river and McMahon creek at Bellaire, R. C. Osburn, I9oo.

\section{Genus: BOLEICH'THYS.}

Boleichthys fusiformis (Girard),

Head $3 \frac{1}{2}$ to 4 ; depth $3 \frac{3 / 4}{4}$ to 6 ; eye 3 to 4 . D. VIII to X-9 to I $2 ; A$. II, 6 to 8 ; scales 3-43 to 6o-I2. Body usually elongate, compressed. Head rather long and narrow; snout short, decurved; mouth terminal, lower jaw slightly included; premaxillaries not protractile; gill membranes connected. Cheeks, opercles, nape and breast usually scaled. Lateral line incomplete, high up, often interrupted. Color, olivaceous, the sides and back blotched with darker, pale below; in adult males the sides are usually flecked with crimson; base of caudal with 4 dark spots in a vertical row; spinous dorsal usually blue, with a median crimson band. An extremely variable species.

Jordan records the species for the state as "noticed only in tributaries of the Maumee, in Ohio.' No other collector mentions it. However, it seems to be distributed over northern and central Ohio, in suitable localities. The writer has found it to be rather common in shallow water in Sandusky Bay, and has taken it also in the Huron river at Milan, I899, and in Pippin and Summit lakes and in Licking reservoir, I900.

\section{Family: SERRANIDA.}

\section{Genus: Roccus.}

Roccus chrysops (Rafinesque). WHITE BASS.

Head $3 \frac{1}{2}$; depth $2 \frac{1}{2}$; eye 5 . D. IX-I, I4; A. III, II or I 2 ; scales IO-55 to 65-15. Body rather deep and compressed; back considerably arched. Head subconical; mouth moderate, nearly horizontal, lower jaw slightly projecting. Head scaled to between nostrils. Color, silvery, tinged with golden below; sides with narrow, dusky lines. Length I5 inches. 
An abundant species in Lake Erie, ascending the larger tributaries to some distance. The species is said to be common in the lower Ohio, but no one seems to have noticed it within the limits of the state, though it probably ascends to that distance. Lake Erie, Henshall, I889; Lorain County, "quite common in the lake, ascending the streams to the dams,"' McCormick, I892 ; Maumee river at Grand Rapids, Waterville and Toledo, Kirsch, 1893 ; abundant in Lake Erie at Sandusky, rare in Huron river at Milan, R. C. Osburn, I899.

\section{Family: SCIAENIDA.}

\section{Genus: APlodinotus.}

\section{Aplodinotus grunniens Rafinesque. SHEEPSHEAD; DRUM; WHITE PERCH.}

Head $3 \frac{1}{3}$; depth $23 / 4$; eye 3 . D. X, 30; A. II, 7. scales 9-55-13. Body oblong; back much elevated and compressed; profile long and steep, straightish. Head slightly compressed; mouth moderate, subinferior. Lower pharyngeal bones fully united, with course, blunt, paved teeth. Color, grayish silvery, dusky above, sometimes very dark; back sometimes with dusky. streaks along the rows of scales. Attaining a weight of 50 or 60 pounds.

An abundant species both in Lake Erie and the Ohio river, and ascending their larger tributaries to some distance. Kirtland, following Le Sueur, recorded the lake form as Scicna oscula, and the Ohio river form as $S$. grisea. Jordan gives it as very abundant in Lake Erie, and also mentions it for the Ohio. Hamilton County, "abundant in Ohio river," Henshall, 1888; Lorain County, "very common in the lake, Vermillion river, Black river," McCormick, 1892; Maumee river at Defiance, Grand Rapids, Waterville and Toledo, west end of Lake Erie, Kirsch, I893; Muskingum river at McConnellsville, Prof. D. S. Kellicott; Ohio river at Ironton, Huron river at Milan, Lake Erie at Sandusky, R. C. Osburn, I899; Ohio river at Bellaire, R. C. Osburn, Igoo, 


\section{Family: COTTIDA. \\ Genus: Cotтus.}

Cottus ictalops (Rafinesque). MILI,ER's THumb; SPRING Fish.

Head about $3 \frac{1}{3}$; depth 4 to 6 ; eye 4 . D. VI to VIII-I6 or I7; A. about I2; ventral fin $I, 4$, the spine slender and closely attached to the first ray. Body stout anteriorly, tapering regularly back to the slender caudal peduncle. Skin smooth, except just behind the pectorals, where it is beset with very small, sharp prickles, these sometimes obsolete; lateral line conspicuous. Gill membranes not meeting across the very broad isthmus. Olivaceous, more or less barred and speckled with darker; fins mostly barred or mottled. Qnite variable. Males in breeding season with a wide, black bar margined with orange on dorsal fin, and under side of head pigmented with dark or blue-black. Length 3 to 7 inches.

Widely distributed, but never abundant; sometimes locally common. It occurs in clear, cold brooks and rapid streams. Recorded as Cottus bairdii, by Girard, from specimens taken by Spencer F. Baird, in Mahoning river at Poland. Given by Jordan as C. richardsoni; Lorain County, common in Spring brook and Chance creek, McCormick, I892; Maumee river system, St. Joseph river at Edgerton, Kirsch, I893; Franklin County, four specimens from Brackenridge's Run, Williamson and Osburn, I 897 ; Big Jelloway creek system, Knox County, Parker's Run and Black's Run, common in the latter, Parker, Williamson and Osburn, I 898 ; a small brook tributary to North Fork of Licking river at Newark, R. C. Osburn, I899.

$$
\begin{aligned}
& \text { Family: GADIDA } \\
& \text { Genus: LотA. }
\end{aligned}
$$

Lota maculosa (Le Sueur). BURBoT; LING; LAKE LAWYER.

Head $4 \frac{1}{2}$; depth $5 \frac{1}{2}$; eye 7 . D. I3-76; A. 68; scales very small, embedded. Body elongate, not much compressed anteriorly. Head slightly depressed; mouth large; a single barbel on the chin. 30 pyloric coeca. Color, dark olive, thickly marbled and reticulated with blackish; below, yellowish or dusky. Length about 2 feet.

Common in Lake Erie, not recorded elsewhere in the state. Recorded for Lake Erie by Le Sueur, I8I7, by Kirtland, I838; by Henshall, I888, and by McCormick for Lorain County, Lake Erie, I892; Sandusky, R. C. Osburn, I 899 arid I900. 


\section{INDEX TO FAMILIES AND GENERA.}

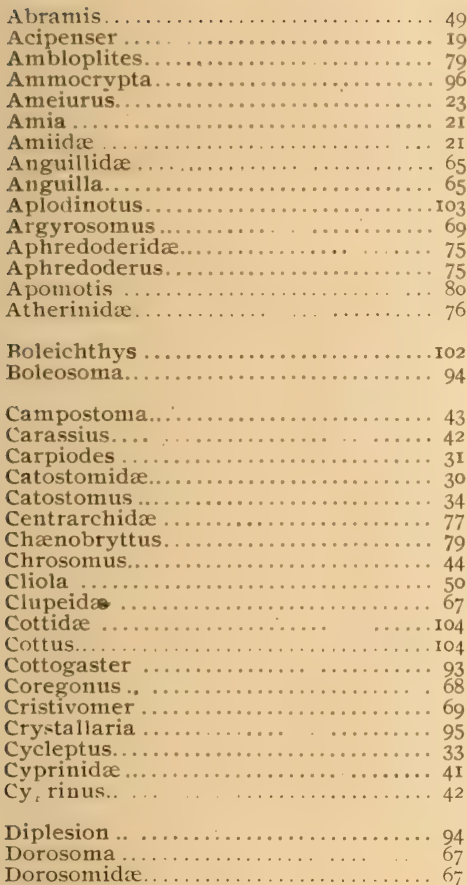

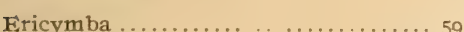

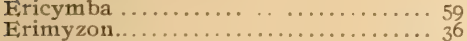

Etheostoma..... ... ... . . . 97

Eucalia ......................... . 74

Eupomotis ........... 83

Exoglossum....................64

Fundulus ... . . . . . . . . . . . . . . 73

Gadidx... $\quad \ldots . \ldots \ldots \ldots \ldots \ldots$. . . . . 04

Gasterosteidæ.................

Hadropterus. . . . . . . . . . . . . 9I

Hiodon........ ................ 66

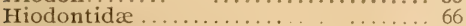

Hybognathus .................... 44

Hybopsis........................ 62
Ichthyomyzon $\ldots \ldots \ldots \ldots \ldots \ldots \ldots$ I5

Ictalurus........................

Ictiobus ........................ 30

Labidesthes ................... 76

Iagochila .................... 40

Lampetra ..................... I6

Lepisosteidæ..................... 20

Lepisosteus...................... 20

L,epomis ..................... 8I

Leptops........................ 26

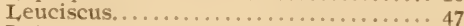

Lota . ..................... ro

Luciida $\ldots \ldots \ldots \ldots \ldots \ldots \ldots \ldots \ldots \ldots \ldots$

Lucius.................. 7I

Micropterus.................... 85

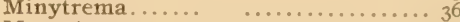

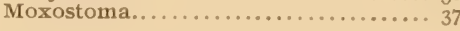

Notropis.................... 5

Noturus...............................

Opsopœeodus.....................48

Perca........................ 89

Percidæ........................ 87

Percina ........................ 89

Percopsidæ..................... . 75

Percopsis...................... 75

Pimephales ....................... 45

Placopharynx..................... 39

Polyodon.......................... 18

Polyodontidæ .................... I8

Pœeciliidæ....................... 73

Pomolobus..................... 67

Pomoxis ..................... 77

Rhinichthys. .................6 60

Roccus.....................

Salmonidæ.................... 68

Salvelinus.. . ................ 70

Scaphirhynchus................... I9

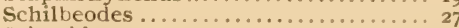

Sciænidæ......................... 103

Semotilus ....................46

Serranidæ.........................

Siluridæ ....................... 22

Stizostedion........................... 88

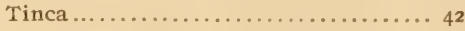

Umbra........................ 70

Umbridæ................................ 70 
4

LQ N D 







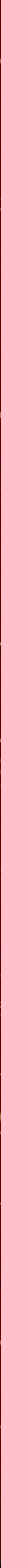




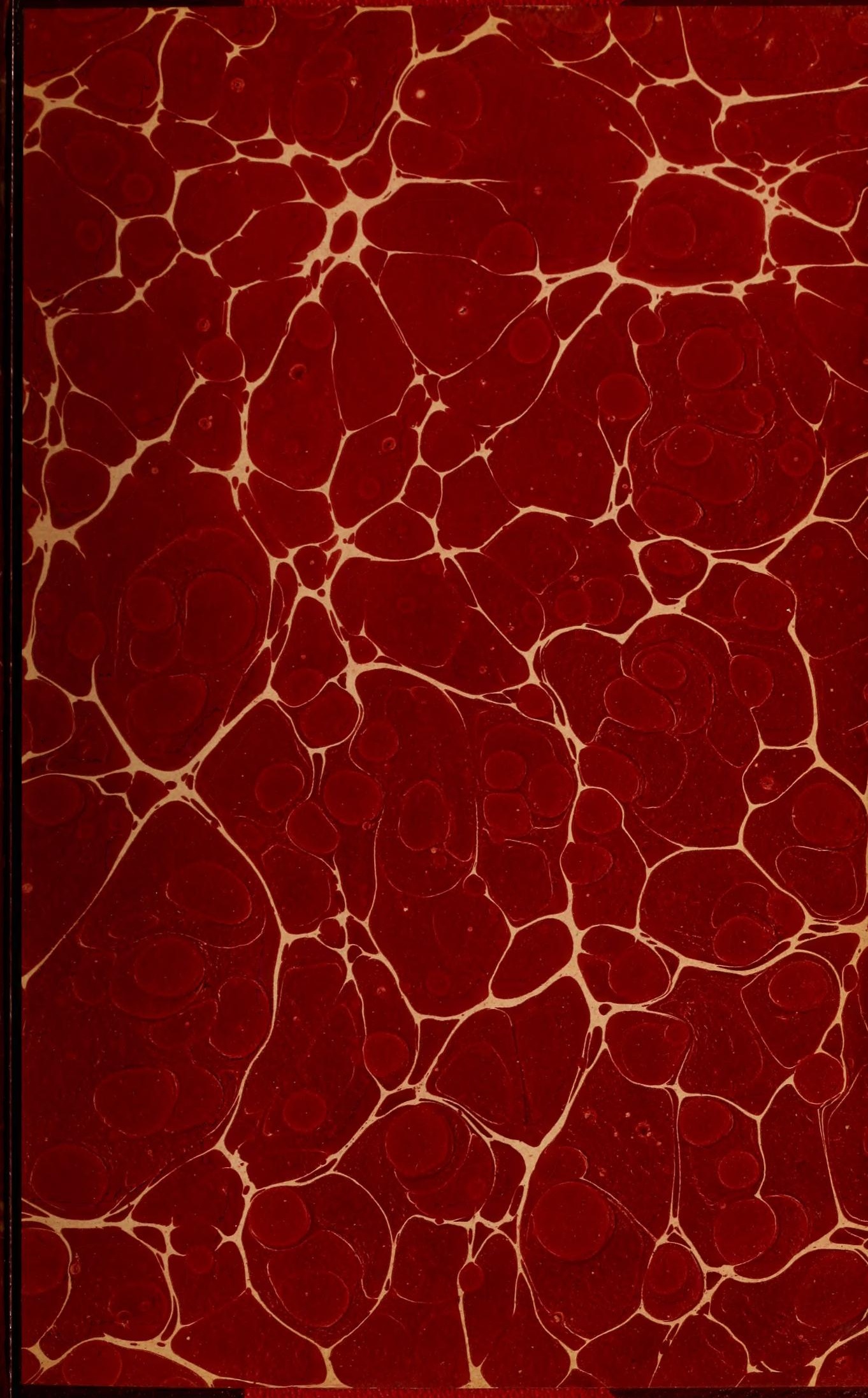




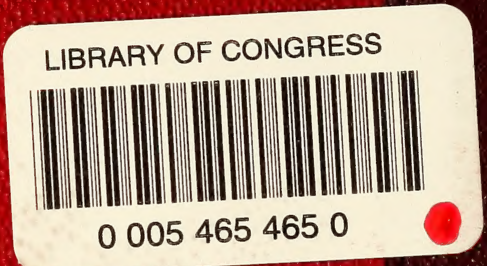

